\title{
MANEJO DE IRRIGAÇÃO POR GOTEJAMENTO PARA APLICAÇÃO DE ÁGUA RESIDUÁRIA VISANDO A MINIMIZAÇÃO DO ENTUPIMENTO DE EMISSORES
}

\author{
Denis Cesar Cararo
}

Tese apresentada à Escola Superior de Agricultura "Luiz de Queiroz", Universidade de São Paulo, para obtenção do título de Doutor em Agronomia, Área de Concentração: Irrigação e Drenagem.

PIRACICAB A

Estado de São Paulo - Brasil

Setembro - 2004 


\title{
MANEJO DE IRRIGAÇÃO POR GOTEJAMENTO PARA APLICAÇÃO DE ÁGUA RESIDUÁRIA VISANDO A MINIMIZAÇÃO DO ENTUPIMENTO DE EMISSORES
}

\author{
Denis Cesar Cararo \\ Engenheiro Agrônomo
}

Orientador: Prof. Dr. TARLEI ARRIEL BOTREL

\begin{abstract}
Tese apresentada à Escola Superior de Agricultura "Luiz de Queiroz", Universidade de São Paulo, para obtenção do título de Doutor em Agronomia, Área de Concentração: Irrigação e Drenagem.
\end{abstract}

PIRACICAB A

Estado de São Paulo - Brasil

Setembro - 2004 


\section{Dados Internacionais de Catalogação na Publicação (CIP) DIVISÃO DE BIBLIOTECA E DOCUMENTAÇÃO - ESALQ/USP}

\section{Cararo, Denis Cesar}

Manejo de irrigação por gotejamento para aplicação de água residuária visando a minimização do entupimento de emissores / Denis César Cararo. - - Piracicaba, 2004. 130 p. : il.

Tese (doutorado) - - Escola Superior de Agricultura Luiz de Queiroz, 2004.

Bibliografia.

1. Águas residuárias 2. Ar comprimido 3. Cloração 4. Irrigação por gotejamento Entupimento I. Título

CDD 631.7 


\section{DEDICATÓRIA}

À Deus, cuja fé conforta e nos conduz adiante em busca da felicidade

Aos meus pais Dionizio e Aldona, irmão Gil e irmãs Denise e Deisy pelo carinho e amor incondicional

À Daniele pela sua companhia e amor

Às pessoas que estiveram entre nós e nos deixaram boas lembranças

À todos que tentam fazer o mundo cada vez melhor

Às futuras gerações que viverão da herança humana

À água por tudo o que ela representa a todos nós no presente e no futuro 


\section{AGRADECIMENTOS}

A Universidade do Estado de São Paulo por ter me recebido para o desenvolvimento deste curso;

A Tarlei Arriel Botrel pela sua presença como orientador e amigo;

Aos funcionários da Estação de Tratamento de Esgoto da Bacia do Ribeirão Piracicamirim pelo auxílio proporcionado;

Ao SEMAE/Piracicaba pelo fornecimento de área, água e energia necessários;

Ao Departamento de Produção Vegetal por ter cedido parte da área para a condução do experimento;

Aos professores dos Departamentos de Engenharia Rural, de Ciências Exatas e de Produção Vegetal : Tarlei, Sergio Duarte, Rubens Coelho, Frizzone, Cruciani, Folegatti, Libardi, Angelocci e Durval pelo prazer demonstrado na troca de conhecimentos durante as disciplinas realizadas;

Àos professores Tarlei, Sergio, Rubens, Ênio e Fernando Mendonça pelas sugestões na elaboração deste trabalho;

Às empresas que forneceram material para a execução da fase experimental; 
A FAPESP pelo apoio financeiro fundamental à pesquisa e ao bolsista;

Aos funcionários do Departamento de Engenharia Rural : Davilmar, Hélio, Sandra, Osvaldo, Gilmar, Lino e "Seu" Antônio pela eficiência e disposição de trabalho;

A Daniele e aos meus pais e irmãos pelos momentos que passamos juntos;

Aos colegas de curso pela amizade, pelos momentos durante $\mathrm{o}$ cafezinho e auxílio ao trabalho efetivado, em especial aos colegas de sala : Nícolas, Tamara, Walter, Olívio, Maurice, Rúben, Rodrigo, Rogério, Miguel e Tadeu;

Aos colegas do Grupo de Práticas em Irrigação e Drenagem que se fizeram presentes me auxiliando na coleta de água durante as avaliações de vazão;

A "Impidido" e a "Salmonela" pelo interesse dedicado durante a fase experimental;

A Harold pelo auxílio prestado e juntamente aos colegas da Sunwise CoOp pela amizade e momentos de descontração durante a estadia nos E.U.A.;

Ao professor David J. Hills, pela recepção na UCDavis e pelas sugestões na discussão dos resultados;

Aos colegas que adoeceram ou já se foram nos deixando saudade pelos bons momentos e alegria proporcionados;

A todos que direta ou indiretamente contribuíram para a concretização deste trabalho e me auxiliaram durante o curso, pessoal e profissionalmente. 


\section{CURRICULUM VITAE}

\section{Denis Cesar Cararo}

$>$ Nascido em 08.12.1974 na cidade de Curitiba - PR

$>$ Realizou cursos de almoxarifado, datilografia e informática, anteriores a graduação

> Engenheiro Agrônomo pela Universidade do Estado de Santa Catarina (UDESC) em 1997

$>$ Mestre em Agronomia com Área de Concentração em Irrigação e Drenagem pela Universidade de São Paulo (USP) em 2000

$>$ Doutor em Agronomia com Área de Concentração em Irrigação e Drenagem pela Universidade de São Paulo em 2004

> Bolsista do Conselho Nacional de Desenvolvimento Científico e Tecnológico (CNPq) de 1995 a 1997

$>$ Bolsista da Coordenação de Aperfeiçoamento de Pessoal de Nível Superior (CAPES) de 1997 a 2000 
> Recebeu prêmio de mérito universitário catarinense e de primeiro colocado da turma do curso de Agronomia em 1997

> Realizou estágios em empresas de pesquisa e extensão agrícola

Desenvolveu pesquisas na área de gênese de solos, de irrigação e de drenagem

> Realizou estágio na "University of Califonia" em Davis, CA (UCDavis) de outubro de 2003 a abril de 2004

> Participou de congressos brasileiros de engenharia agrícola (CONBEA) com apresentação de trabalhos de 1999 a 2004, e de eventos internacionais em 2004

Apresenta bom nível em inglês e razoável em espanhol

Atuou nas áreas de avaliação de canhão hidráulico e de função de produção em tomateiro e aplicação de dióxido de carbono via água de irrigação

Atua na área de entupimento de gotejadores de sistemas de irrigação e uso de águas residuárias na agricultura 


\section{SUMÁRIO}

Página

LISTA DE FIGURAS ...................................................................

LISTA DE TABELAS .................................................................. xiv

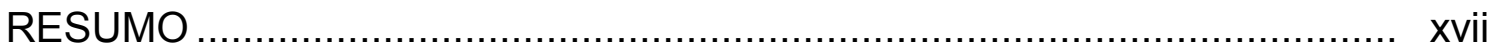

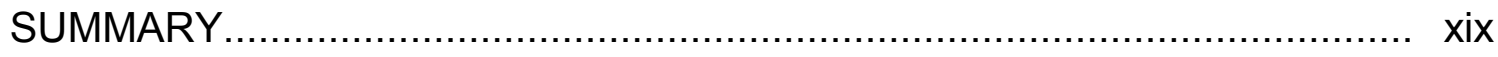

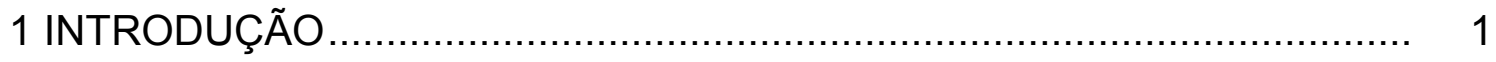

2 REVISÃO DE LITERATURA .............................................................. 3

2.1 Uso da água residuária na agricultura ............................................... 3

2.2 Irrigação com águas residuárias ........................................................ 6

2.3 Vantagens e limitações do sistema de irrigação por gotejamento ............ 6

2.4 Causas de entupimento em sistemas de irrigação por gotejamento......... 9

2.5 Susceptibilidade dos gotejadores ao entupimento ................................ 10

2.6 Técnicas para minimizar o entupimento …....................................... 12

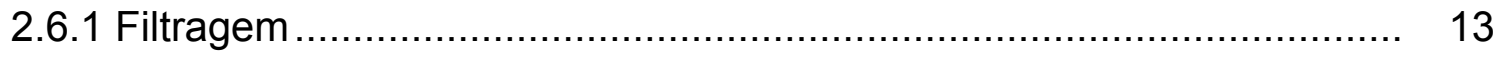

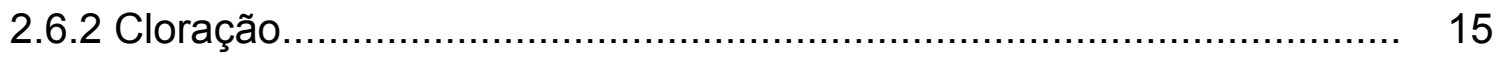

2.6.3 Combinação entre filtragem e cloração ............................................ 17

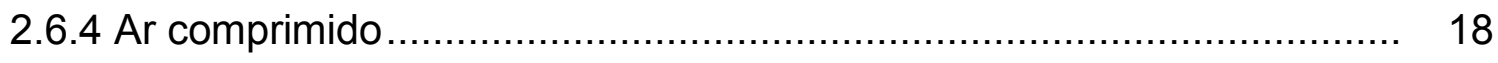

3 MATERIAL E MÉTODOS …...................................................... 20

3.1 Caracterização dos gotejadores novos ............................................ 20

3.1.1 Localização e período dos ensaios ................................................... 20

3.1.2 Modelos de gotejadores amostrados ........................................... 20 
3.1.3 Descrição da montagem para realização dos ensaios laboratoriais ..... 24

3.1.4 Ensaio para a determinação da vazão, do coeficiente de variação de fabricação e da uniformidade de distribuição...................................... 25

3.1.5 Ensaio para a determinação da curva vazão versus pressão............... 27

3.2 Estudo da susceptibilidade dos gotejadores ao entupimento ................. 28

3.2.1 Localização e período da segunda etapa ........................................ 28

3.2.2 Descrição e montagem do sistema de irrigação ................................. 28

3.2.3 Qualidade da água residuária .................................................. 33

3.2.4 Aplicação da água residuária ............................................................ 33

3.2.5 Avaliações de vazão ................................................................... 36

3.2.6 Seleção dos emissores .......................................................... 37

3.2.7 Visualização do entupimento pelo uso de água residuária ................... 38

3.3 Estudo dos manejos preventivos ao entupimento................................ 39

3.3.1 Localização e período da terceira etapa ........................................... 39

3.3.2 Modelos de gotejadores selecionados .......................................... 39

3.3.3 Descrição e montagem do experimento ......................................... 40

3.3.4 Manejos preventivos ao entupimento ........................................... 43

3.3.5 Execução dos tipos de manejo propostos......................................... 46

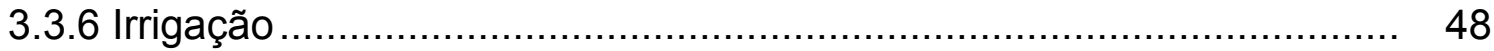

3.3.7 Avaliações de vazão .............................................................. 50

3.3.8 Seleção dos modelos de gotejadores versus tipos de manejo ............. 51

3.3.9 Qualidade da água residuária ................................................... 51

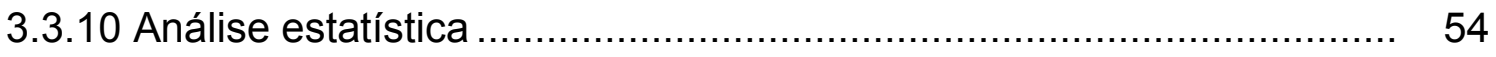

3.3.11 Análise probabilística da vazão dos gotejadores …......................... 55 
4 RESULTADOS E DISCUSSÃO .......................................................... 56

4.1 Caracterização dos gotejadores novos ……..................................... 56

4.2 Estudo da susceptibilidade dos gotejadores ao entupimento ................ 61

4.2.1 Qualidade da água relacionadas ao risco de entupimento ................. 61

4.2.2 Avaliações de vazão e do entupimento ............................................ 62

4.2.3 Avaliação visual do entupimento.................................................... 69

4.2.4 Avaliações de vazão e aumentos de vazão ....................................... 70

4.2.5 Modelos de gotejadores selecionados .......................................... 74

4.3 Estudo dos manejos preventivos ao entupimento................................ 75

4.3.1 Qualidade da água, entupimento e filtragem .................................. 75

4.3.2 Coeficiente de variação de vazão ................................................... 77

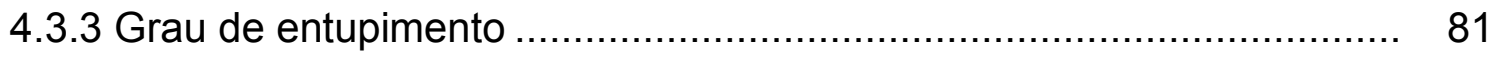

4.3.4 Análise probabilística da vazão dos gotejadores ............................... 85

4.3.5 Sugestões para trabalhos futuros …............................................. 89

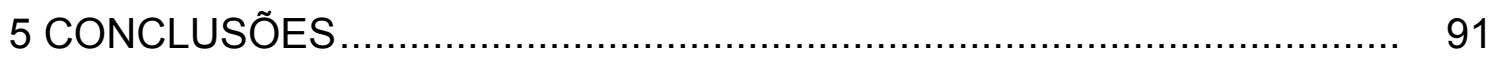

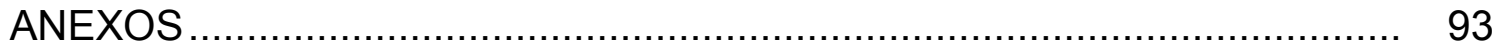

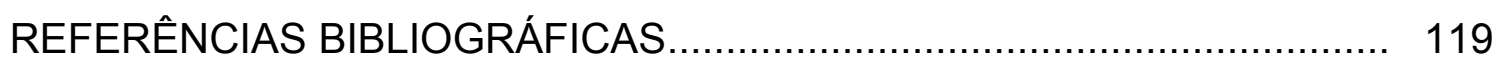




\section{LISTA DE FIGURAS}

Página

1 Tipos de gotejadores conforme o sistema de funcionamento e forma...... 22

2 Instalação utilizada para realizar os ensaios laboratoriais....................... 25

3 Instalação utilizada para o estudo da sensibilidade dos gotejadores ao entupimento.

4 Posição das tubulações referentes a cada modelo de gotejador na linha de derivação e ponto de controle de pressão com registro de agulha....... 30

5 Curvas características de bombas de água centrífugas, marca KSB, utilizadas no experimento (C 500 e C 1000).

6 Número de horas de funcionamento do sistema de irrigação com aplicação da água residuária e avaliações de vazão realizadas

7 Gráfico para exemplificação da análise probabilística de vazão utilizada na segunda e terceira etapas deste trabalho.

8 Curva característica de bomba de água centrífuga, marca KSB, utilizada no experimento (C 1000N).

9 Croqui da instalação hidráulica a campo para seleção dos manejos preventivos ao entupimento (terceira etapa do trabalho).

10 Cabeçal de controle para o estudo dos modelos de gotejador versus manejos preventivos ao entupimento (terceira etapa do trabalho).

11 Tempos de funcionamento do sistema de irrigação e de ar comprimido utilizados na terceira etapa, e momentos em que se efetuaram as avaliações de vazão.

12 Curvas vazão $(q)$ versus pressão $(H)$ dos gotejadores novos, obtidas em laboratório. 
13 Valores médios de grau de entupimento dos modelos de gotejador ao longo das avaliações de vazão a partir de uma amostra de 6 emissores

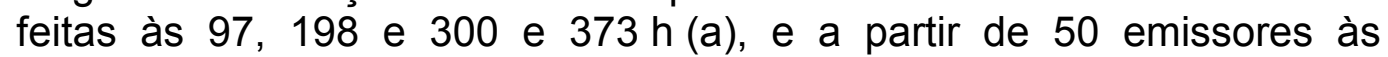
373 horas de aplicação de água residuária (b) ...................................... 66

14 Imagens de gotejadores abertos mostrando o entupimento................... 70

15 Graus de entupimento relacionados às vazões relativas da $2^{\mathrm{a} / 1^{\mathrm{a}}}, 3^{\mathrm{a} / 1^{\mathrm{a}}} \mathrm{e}$

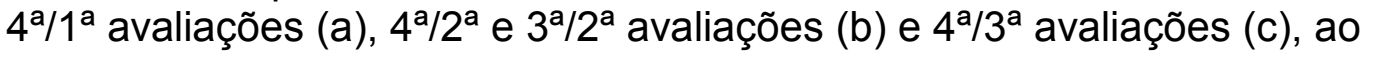
invés de $1^{\mathrm{a}}, 2^{\mathrm{a}}, 3^{\mathrm{a}}$ e $4^{\mathrm{a}}$ avaliações/avaliação de gotejadores novos.........

16 Representação gráfica dos dados diários da precipitação pluviométrica e da evaporação de água no tanque classe "A" ...................................... 


\section{LISTA DE TABELAS}

Página

1 Classificação de águas residuárias tratadas conforme o uso segundo a Organização Mundial de Saúde.

2 Classificação de águas tratadas conforme os grupos de risco à saúde (GR), níveis de nematóides intestinais (NI) e coliformes fecais (CF) e o tratamento requerido (TR) segundo a Organização Mundial de Saúde...... 5

3 Critérios para classificação do potencial de risco de águas no entupimento de sistemas de irrigação localizada

4 Cloro residual livre para controle orgânico e de precipitados em sistemas de irrigação

5 Características dos gotejadores testados de acordo com o espaçamento entre emissores $\left(E_{e}\right)$, vazão de catálogo a pressão de $98 \mathrm{kPa}\left(\mathrm{V}_{\mathrm{c}}\right)$, coeficiente de variação de vazão em catálogo $\left(\mathrm{CV}_{\mathrm{c}}\right)$, comprimento de passagem de água $\left(C_{p}\right)$, seção de passagem mais estreita $\left(S_{e}\right)$, profundidade da passagem de água $\left(P_{p}\right)$, espessura da parede da

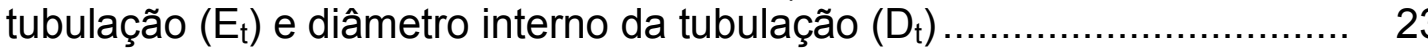

6 Diâmetro efetivo $\left(D_{e}\right)$, resistência mecânica $\left(R_{m}\right)$, resistência química $\left(R_{q}\right)$, forma dos grãos $\left(F_{g}\right)$ e coeficiente de uniformidade da areia $\left(\mathrm{CU}_{\mathrm{a}}\right) \ldots \ldots \ldots \ldots$.

7 Demanda bioquímica de oxigênio (DBO),degradação química de oxigênio (DQO), sólidos totais (ST), sólidos suspensos (SS), sólidos dissolvidos (SD), alcalinidade total (maioria carbonato) (AT), nitrogênio total (N), fosfato $\left(\mathrm{PO}_{4}\right)$, oxigênio dissolvido $(\mathrm{OD})$ da água residuária utilizada no primeiro semestre de 2002

8 Potencial hidrogeniônico $(\mathrm{pH})$, coliformes totais $(\mathrm{CT})$, coliformes fecais (CF), turbidez e temperatura $(\mathrm{T})$ da água residuária utilizada no primeiro semestre de 2002

9 Desníveis geométricos médios em relação ao cabeçal de controle e pressões médias no início das linhas gotejadoras, calculadas para $65 \mathrm{kPa}$ no ponto de controle. 
10 Características referentes às coletas de água realizadas antes (AF) e depois (DF) da filtragem para condutividade elétrica (CE), $\mathrm{pH}$, nitrogênio total $(\mathrm{N})$, demanda bioquímica de oxigênio (DBO) e demanda química de oxigênio (DQO) .

11 Características biológicas e físicas analisadas referentes às coletas de água realizadas antes (AF) e depois (DF) da filtragem.............................

12 Características químicas analisadas referentes às coletas de água

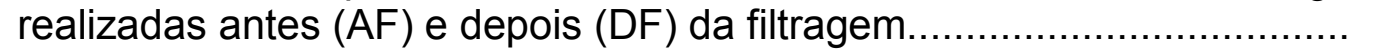

13 Esquema da análise de variância utilizada na terceira etapa do trabalho para o grau de entupimento e o coeficiente de variação

14 Valores médios de vazão ( $q_{\text {novo }}$ ), coeficiente de variação de fabricação $\left(C V_{f}\right)$ e uniformidade de distribuição $\left(U D_{\text {novo }}\right)$ para pressão de ensaio de $98 \mathrm{kPa}$

15 Coeficientes de variação de vazão antes $\left(\mathrm{CV}_{\mathrm{f}}\right)$ e após $\left(\mathrm{CV}_{\mathrm{q}}\right)$ a aplicação de 373 horas de água residuária, e a uniformidade de distribuição antes $\left(U D_{\text {novo }}\right)$ e após $\left(U D_{373} \mathrm{~h}\right)$ esse período para os modelos de gotejadores testados

16 Probabilidade de encontrar emissores com vazão na faixa de variação de $\pm 5 \%$ em relação à vazão quando novo após 373 horas de aplicação de água residuária

17 Valores de coeficiente de variação de vazão (\%) em diferentes tipos de manejo versus modelos de gotejador após a irrigação com água residuária para três avaliações completas de vazão realizadas na terceira etapa

18 Valores de coeficiente de variação de vazão (\%) em diferentes modelos de gotejador versus tipos de manejo após a irrigação com água residuária para três avaliações completas de vazão realizadas na terceira etapa

19 Graus de entupimento (\%) em diferentes tipos de manejo versus modelos de gotejador após a irrigação com água residuária para três avaliações completas de vazão na terceira etapa do trabalho

20 Graus de entupimento (\%) em diferentes tipos de manejo versus modelos de gotejador após a irrigação com água residuária para três avaliações completas de vazão na terceira etapa do trabalho

21 Resultado da análise de regressão para grau de entupimento (GE) em função do período em que a terceira etapa foi conduzida (t).... 
22 Probabilidades (\%) de encontrar gotejadores com vazão na faixa de variacão de $\pm 5 \%$ em relação à vazão média dos mesmos quando novos, após a irrigação com água residuária para três avaliações completas de vazão realizadas na terceira etapa do trabalho ..................

23 Percentagem de emissores com vazão inferior a metade da vazão quando novos (qusado $\leq 0,5$ qnovo) e completamente entupidos (GE $=100 \%$ ), após a irrigação com água residuária para três avaliações completas de vazão realizadas na terceira etapa .................. 


\title{
MANEJO DE IRRIGAÇÃO POR GOTEJAMENTO PARA APLICAÇÃO DE ÁGUA RESIDUÁRIA VISANDO A MINIMIZAÇÃO DO ENTUPIMENTO DE EMISSORES
}

\author{
Autor: DENIS CESAR CARARO \\ Orientador: Prof. Dr. TARLEI ARRIEL BOTREL
}

\section{RESUMO}

A escassez de água e a grande geração de esgoto doméstico com necessidade de tratamento estimulam o uso de águas residuárias na agricultura. A irrigação por gotejamento caracteriza-se como um sistema seguro para esta finalidade, mas possui como barreira tecnológica o entupimento dos gotejadores. Neste trabalho, objetivou-se selecionar modelos de gotejadores e manejos mitigadores do entupimento por uso de água residuária oriunda de tratamento secundário de esgoto doméstico. Desenvolveu-se o estudo em três etapas: (I) a caracterização de 15 modelos de gotejador novos, (II) a préseleção dos emissores e (III) a seleção da combinação manejo e modelo. Os manejos foram controle, cloração a $0,5 \mathrm{mg} \mathrm{L}^{-1}$ de cloro residual livre ao final da irrigação medido ao final do sistema, ar comprimido a 1,96 kPa na entrada dos emissores e a combinação de cloração e ar comprimido, utilizando-se filtragem de areia $\left(D_{e}=0,59 \mathrm{~mm}\right)$, disco (120 mesh) e tela (200 mesh) em todos os tratamentos. Procederam-se avaliações de vazão e cálculos de coeficiente de variação de vazão $\left(\mathrm{CV}_{\mathrm{q}}\right)$ e de grau de entupimento $(\mathrm{GE})$. Os modelos apresentaram coeficiente de variação de fabricação aceitável e diferentes sensibilidades ao entupimento. O entupimento foi parcial, ocorreu de maneira 
desuniforme, independente da uniformidade de distribuição de água (UD) do emissor novo, e surgiu pela formação de biofilme bacteriano associado a sólidos dissolvidos. Houve aumentos de vazão em alguns modelos. A cloração reduziu o grau de entupimento ao longo do tempo e evitou o entupimento total em emissores. O modelo $B$ associado à cloração apresentou a maior probabilidade de encontrar emissores na faixa de $5 \%$ de variação de vazão em relação aos novos e o modelo $\mathrm{M}$ associado à filtragem ou a tratamentos com ar comprimido, as menores probabilidades. Os manejos mostraram-se semelhantes quanto ao GE e ao $\mathrm{CV}_{\mathrm{q}}$ e obtiveram-se valores de UD inferiores a $60 \%, \mathrm{CV}_{\mathrm{q}}$ superiores a $20 \%$ e GE superiores a $5 \%$. Finalmente, de acordo com o objetivo, selecionou-se $\mathrm{o}$ modelo $\mathrm{B}$ associado à cloração como a combinação que melhor atenuou o entupimento dos emissores. 


\title{
DRIP IRRIGATION TECHNIQUES TO MITIGATE THE DRIPPER CLOGGING IN WASTEWATER IRRIGATION
}

\author{
Author: DENIS CESAR CARARO \\ Adviser: Prof. Dr. TARLEI ARRIEL BOTREL
}

\section{SUMMARY}

The sustainable management of water resources, given the current and projected severe water shortages, requires that appropriate methods of water usage be implemented. One of these is the application of treated wastewater to agricultural land using drip irrigation systems, which is safe and among the most resource efficient methods of irrigation. However, the use of drip irrigation with wastewater is constrained by the potential for clogging in the emitters. To elucidate the mechanism of clogging, fifteen drip emitters models from different manufacturers were tested with secondary treated wastewater in the laboratory and two field experiments were conducted to evaluate emitters and treatments according to the degree of clogging (DC) and flow rate coefficient of variation $\left(\mathrm{CV}_{\mathrm{q}}\right)$. The treatments were control (filtrage only), chlorination $\left(0.5 \mathrm{mg} \mathrm{L}^{-1}\right.$ free residual chlorine injected at the end of each irrigation cycle), compressed air (1.96 $\mathrm{kPa}$ in the inlet drippers) and the chlorine and compressed air combination. The manufacture coefficient of variation was acceptable and different clogging susceptibility. The clogging was partial, non-uniform and was caused by biofilm with dissolved solids. Some drippers with overflow rates were noted. The chlorination decreased clogging overtime and reduced the complete clogging. The dripper model B (pressure compensated, flat and inserted in the 
line, with rectangular elastic membrane over a $30 \mathrm{~mm}$ passageway, $0.8 \mathrm{~mm}$ narrowest aperture, $1.61 \mathrm{~L} \mathrm{~h}^{-1}$ under $98 \mathrm{kPa}$ ) with chlorination was identified as having the best performance, with the highest number of emitters with a flow rate within five percent of the flow rate when new, and the dripper model $\mathrm{M}$ with chlorination was the worst performance with the lowest percent. The filtrage, chlorine and air treatments did not have a statistically significant affect in the DC or $\mathrm{CV}_{\mathrm{q}}$. Distribution uniformities higher than $60 \%, \mathrm{CVq}$ higher than $20 \%$ and DC higher then $5 \%$ were found. Finally, according to the purposed, It was selected the dripper model $B$ with chlorination as the best combination to mitigate the clogging 


\section{INTRODUÇÃO}

A água é um recurso natural em escassez em muitas regiões do planeta e do Brasil. A alteração antrópica dos padrões físicos, químicos e biológicos na mesma, tem limitado o seu uso e ocasionado danos ambientais em algumas circunstâncas.

Um dos resíduos gerados pela atividade humana é o esgoto doméstico. Uma fração deste resíduo é conduzido a estações de tratamento. Ao chegar a esses locais, o esgoto sofre uma redução no teor de sólidos suspensos, originando lodo e água residuária como subprodutos do tratamento.

O lançamento de água residuária, também conhecida como efluente, reduz o oxigênio dissolvido e aumenta a produção de algas, a deposição de sólidos e o número de coliformes totais nos cursos de água. Dentre os impactos ocasionados por esta prática, tem-se a contaminação da ictiofauna, a mortandade de peixes e o aumento dos custos do tratamento de água para uso potável. Considerando essa realidade, é importante adotar medidas que solucionem ou minimizem o problema relatado.

Dentre as medidas sugeridas para a redução desses impactos está a utilização de águas residuárias na agricultura, que é desejável do ponto de vista agronômico, pois este recurso possui nutrientes úteis às culturas. Nesse contexto, a irrigação é a prática mais usual, viável e conveniente a ser adotada. Esta técnica poderá proporcionar aumentos na produtividade das culturas desde que sejam efetuados tratamentos apropriados ao seu uso. 
Atualmente, um dos sistemas mais apropriados e em notável expansão é o sistema de irrigação por gotejamento, o qual apresenta vantagens como a economia de água e energia, possibilidade de automação e fertirrigação. Além disso, apresenta baixo risco de contaminação de operadores no campo e do produto agrícola final, característica esta que é desejável na aplicação de águas residuárias que apresentem organismos nocivos à saúde humana. Entretanto, tal sistema de irrigação tem como uma das principais limitações o fato de ser susceptível ao entupimento de seus emissores. A sensibilidade ao problema varia com as características do emissor e com a qualidade da água utilizada, seja por causas físicas, químicas e/ou biológicas.

Para a minimização do entupimento são sugeridas diversas técnicas na literatura. Entre as práticas mais usuais estão a filtragem e a cloração. Contudo, o uso de águas residuárias oriundas de estações de tratamento de esgoto doméstico na agricultura é incipiente no Brasil e requer estudo. As medidas combinadas e adotadas para a solução do problema em questão devem ser eficientes, com custo acessível ao produtor irrigante, apresentar baixo risco à saúde humana e não causar danos às plantas cultivadas e ao ambiente. Além disso, também deve ser considerada a criação de novas tecnologias de prevenção ao entupimento, tais como a aplicação de ar comprimido.

Considerando esses aspectos, este trabalho teve por objetivo a seleção de emissores e de manejos preventivos para a minimização do entupimento em sistemas de irrigação por gotejamento com água residuária oriunda do tratamento secundário de esgoto doméstico. 


\section{REVISÃO DE LITERATURA}

\subsection{Uso da água residuária na agricultura}

A população mundial continua aumentando nas últimas décadas e conseqüentemente, verifica-se uma demanda crescente por água e alimentos. Considerando que apenas $4 \%$ do volume total da água está em aqüíferos e menos de $1 \%$ em rios e lagos (Lar \& Stewart, 1994), e que a poluição tem sido um fator importante de redução da disponibilidade, verifica-se que a água é um recurso natural cada vez mais escasso, principalmente a potável. Isto força ao uso de águas de fontes alternativas que possam ser economicamente utilizadas (Pescod, 1992).

Com a expansão das populações urbanas, maiores quantidades de esgoto municipal têm sido produzidas. Aumentou-se também a consciência em utilizá-lo de maneira segura e benéfica, haja visto que o lançamento destes resíduos no ambiente afeta o uso posterior dos mananciais, seja pela poluição, pela demanda de oxigênio na decomposição da matéria orgânica, pela contaminação por microrganismos patogênicos, pela eutrofização ou pela elevação do custo do tratamento de água para fins potáveis, que representam alguns dos impactos gerados (Pescod, 1992; Von Sperling, 1996 e Léon \& Cavallini, 1999).

Várias alternativas são utilizadas para minimizar o problema citado anteriormente. Dentre elas tem-se a disposição do efluente na agricultura, tratado ou não, tendo em vista que esta atividade utiliza maior quantidade de água e permite o uso de águas de menor qualidade quando comparada à 
indústria e ao uso doméstico (Ayers \& Westcot, 1991). Entretanto, como comentado por Bettiol ${ }^{1}$, a agricultura não deve ser usada como aterro sanitário final para disposição de qualquer resíduo. Este deve ser analisado laboratorialmente para assegurar sua aplicabilidade ao destino desejado. Assim, sugere-se preferencialmente a aplicação de efluentes tratados, que possuem menores valores de agentes patogênicos.

Quando o esgoto municipal passa pelas estações de tratamento, se originam dois resíduos, a água residuária e o lodo (Pescod, 1992). O uso planejado de águas residuárias tratadas, na agricultura, ameniza os problemas de poluição das águas superficiais, conservando as águas de maior valor para outros fins. Também tem a vantagem de conter nutrientes necessários ao crescimento de culturas, como é o caso do nitrogênio e do fósforo, que poderiam eliminar a exigência em fertilizantes comerciais (Pescod, 1992). Um exemplo dessa economia é o trabalho realizado por Papadopolous \& Stylianou (1991), no qual foi concluído que quantidades menores de adubos com nitrogênio e fósforo são necessárias para se obter alto rendimento de sementes e boa qualidade em girassol ao utilizar água residuária municipal.

Bastos (1999) também destaca o controle de poluição, a economia de água e fertilizantes, a reciclagem de nutrientes e o aumento de produção agrícola. Este pode ser constatado em trabalhos realizados por Neilsen et al. (1989a e 1989b), nos quais ocorreram aumentos de produtividade em melão, tomate, pimentão, alho, pepino, feijão de vagem e maçã. Assim, ao invés de lançar águas residuárias dos sistemas de tratamento de esgoto em mananciais, pode-se aproveitá-las na irrigação de culturas.

O uso do efluente tratado em questão, na agricultura, apesar das diversas vantagens, requer que se considerem as recomendações estabelecidas pela Organização Mundial de Saúde (WHO, 1989) e

1 BETTIOL, W. Impacto ambiental do uso agrícola do lodo de esgoto e de efluentes /Apresentado no Workshop "Águas residuárias tratadas: presença de patógenos emergentes e o reuso na agricultura", São Paulo, 2004, Universidade de São Paulo Escola Politécnica/ - informação pessoal 
apresentadas nas Tabelas 1 e 2, quanto aos aspectos de tipo de irrigação versus cultura, grupos de risco (agricultores, consumidores e público em geral), níveis de tolerância de nematóides e coliformes fecais, e o processo de tratamento utilizado. Além disso, deve-se observar requisitos e padrões de qualidade em função do uso previsto, que podem ser encontrados em Pescod (1992) e Léon S. \& Cavallini (1999).

Tabela 1. Classificação de águas residuárias tratadas conforme o uso segundo a Organização Mundial de Saúde

\begin{tabular}{cc}
\hline Categoria & Condição de uso \\
\hline A & Em culturas não aptas para o consumo humano; em culturas \\
& cujos produtos são processados a altas temperaturas, verduras e \\
frutas cultivadas exclusivamente para enlatados e ou que sofrem \\
outros processamentos que eliminam microorganismos patogênicos; \\
cultivo de forrageiras para fornecimento a seco para os animais; e \\
em áreas cercadas e sem acesso ao público \\
B pm pastagens e forrageiras consumidas verdes, cultivos cujo \\
produto de consumo humano não tenha contato direto com a água \\
residuária e/ou ingeridos cozidos e/ou consumidos após serem \\
descascados, e cultivos irrigados por aspersão \\
Irrigação localizada sem exposição de trabalhadores e publico \\
em áreas com acesso ao público, e para todo produto que seja \\
ingerido cru e cultivado em contato com efluentes de estações de \\
tratamento de águas residuárias
\end{tabular}

Tabela 2. Classificação de águas residuárias tratadas conforme os grupos de risco à saúde (GR), níveis de nematóides intestinais $(\mathrm{NI})$ e coliformes fecais (CF) e o tratamento requerido (TR)

\begin{tabular}{ccccc}
\hline Categoria & GR & $\begin{array}{c}\mathrm{Nl} \\
\text { (ovos / litro) }\end{array}$ & $\begin{array}{c}\mathrm{CF} \\
\left(\mathrm{n}^{\circ} / 100 \mathrm{ml}\right)\end{array}$ & $\mathrm{TR}$ \\
\hline $\mathrm{A}$ & $\begin{array}{c}\text { Trabalhadores } \\
\text { do campo }\end{array}$ & $\leq 1$ & $\leq 1000$ & $\begin{array}{c}\text { Lagoas de } \\
\text { estabilização em série } \\
\text { ou tratamento } \\
\text { equivalente }\end{array}$ \\
B & $\begin{array}{c}\text { Trabalhadores } \\
\text { do campo, } \\
\text { consumidor } \\
\text { Nenhum }\end{array}$ & $\leq 1$ & $\begin{array}{c}\text { Sem padrão } \\
\text { recomendado }\end{array}$ & $\begin{array}{c}\text { 8-10 dias em lagoas de } \\
\text { estabilização ou até } \\
\text { remoção de CF }\end{array}$ \\
a & Nãcánel aplicável & $\begin{array}{c}\text { Pré-tratamento, mas } \\
\text { não menos que } \\
\text { sedimentação primária }\end{array}$ \\
\hline
\end{tabular}




\subsection{Irrigação com águas residuárias}

Conforme mencionado anteriormente, com a expansão da população há a necessidade de se obter maiores produções. Assim, novamente a irrigação apresenta um papel relevante, visto que além de possibilitar aumento da

produtividade, permite a melhoria do padrão de vida rural. Entretanto, com o uso de águas de qualidade marginal, exige-se um monitoramento mais intenso comparado à água de uso irrestrito (Pescod, 1992).

A irrigação com águas residuárias pode contaminar o ar, os solos e as plantas nos campos irrigados e áreas vizinhas. A magnitude da contaminação depende do tratamento dessas águas, das condições climáticas predominantes, da cultura irrigada e do próprio sistema de irrigação (Ayers \& Westcot, 1991).

Diversos são os sistemas de irrigação atualmente utilizados, entre eles destacam-se os sistemas por inundação, por faixas, por sulcos, por gotejamento, por microaspersão, por aspersão e por subsuperfície (Scaloppi, 1986). Estabelecendo como critério de seleção a qualidade da água de irrigação, a subirrigação por tubulações e a irrigação por gotejamento constituem os sistemas mais seguros e apresentam menores riscos de contaminação (Ayers \& Westcot, 1991), porque existe menor contato do irrigante e da parte aérea das plantas com o efluente.

\subsection{Vantagens e limitações do sistema de irrigação por gotejamento}

Segundo Scaloppi (1986), os sistemas de irrigação que aplicam a água de forma localizada, ou seja, na região do sistema radicular, se caracterizam pela economia de água, pela pequena utilização de mão-de-obra, pela susceptibilidade a entupimentos ou mal funcionamento de seus componentes, pelo grande potencial de automatização, pela manutenção de elevados níveis de água no solo para melhorar o desempenho das culturas, pela possibilidade de se adequar às condições de solos pedregosos, rasos e topografia 
acidentada, pela possibilidade de aplicação de produtos químicos em solução na água de irrigação e pela redução dos riscos de contaminação das culturas.

Hanson \& Lamm (1995) apontam ainda como vantagens, a economia de fertilizantes, redução de custos culturais e o aumento em produtividade. Todas essas são razões pelos quais a utilização destes sistemas tem crescido no Brasil. Segundo Oron et al. (1992), tanto a irrigação superficial como a subsuperficial por gotejamento são promissoras tecnologias para satisfazer problemas de escassez e poluição de águas.

Contudo, a irrigação por aplicação localizada apresenta limitações, tais como o elevado custo inicial e de manutenção, rompimento de tubulações, danos causados por roedores, necessidade de operadores habilitados e o fator mais limitante: a obstrução dos emissores e tubulações por sedimentos e crescimento microbiano (Scaloppi, 1986; Ayers \& Westcot, 1991; Hanson \& Lamm, 1995 e Silvanappan \& Lamm, 1995).

O entupimento é agravado pelo uso de águas residuárias, aumentando os custos fixos (menor vida útil), reduzindo a uniformidade de aplicação e de distribuição da água devido aos elevados teores de sólidos em suspensão e algas (Chandrakanth et al., 1988; Bastos, 1999), aumentando os custos operacionais e necessitando de checagem, troca e recuperação de emissores com mal funcionamento, que são mais freqüentes ao final da linha de irrigação (Bucks et al., 1979).

Segundo Parchomchuk (1976), Solomon (1979) e Lopez et al. (1997) a uniformidade de aplicação também sofre influência da temperatura, características de fabricação dos emissores, diferenças de pressão no sistema e relevo da área. A uniformidade de aplicação pode ser melhorada pelo uso de maior número de gotejadores por planta, porém com aumento do custo de implantação.

A precipitação química, a formação de filmes biológicos e depósitos de partículas inorgânicas no interior das canalizações e gotejadores são riscos presentes (Bastos, 1999). Tajrishy et al. (1994) ressaltam o problema quando 
afirmam que o entupimento de uma pequena percentagem dos emissores pode afetar severamente a uniformidade de aplicação da água. No trabalho realizado por Nakayama \& Bucks (1981), foi verificado que de 1 a $5 \%$ dos emissores entupiram quando se utilizou de 2 a 8 emissores por planta, resultando em desuniformidade de distribuição de água. Smajstrla (1995) acrescenta também a redução na uniformidade de aplicação de nutrientes, de crescimento e de rendimento das plantas.

Smajstrla (1991) aponta que os sistemas de microirrigação, como o gotejamento, normalmente requerem um maior nível de manejo em relação aos demais sistemas, incluindo freqüentes inspeções e uso de medidores de vazão e pressão para verificar se o sistema está funcionando como definido no projeto.

Dentre as inspeções, o monitoramento da qualidade da água é um fator de grande importância, incluindo análises da condutividade elétrica, dos sólidos em suspensão, dos conteúdos de ferro total, cálcio, magnésio e manganês, da demanda química e bioquímica de oxigênio, do teor de matéria orgânica, dos microorganismos presentes, do conteúdo de oxigênio dissolvido e de sólidos dissolvidos totais (Ayers \& Westcot, 1991). Pode-se avaliar e classificar o potencial de risco ao entupimento com o uso de um ou mais desses critérios combinados (Capra \& Scicolone, 1998), como apresentados na Tabela 3.

Estando o sistema entupido, as alternativas são a troca dos emissores ou, segundo Gilbert et al. (1979), a realização de processos de recuperação, que aumenta o custo de manutenção ao sistema e, em algumas circunstâncias, pode ser ineficiente. Assim, a prevenção ao aparecimento da obstrução nos emissores e nas linhas de distribuição é melhor em relação à recuperação, conforme foi sugerido por Resende (1999). 
Tabela 3. Critérios para classificação do potencial de risco de águas no entupimento de sistemas de irrigação localizada

\begin{tabular}{|c|c|c|c|c|}
\hline \multirow{2}{*}{$\begin{array}{c}\text { Causa obstrutora } \\
\text { potencial }\end{array}$} & \multirow[t]{2}{*}{ Unidade } & \multicolumn{3}{|c|}{ Grau de restrição ao uso } \\
\hline & & Nenhum & Leve a moderado & Severo \\
\hline Sólidos suspensos & $\mathrm{mg} / \mathrm{L}$ & $<50$ & $50-100$ & $>100$ \\
\hline $\mathrm{pH}$ & $\mathrm{mg} / \mathrm{L}$ & $<7,0$ & $7,0-8,0$ & $>8,0$ \\
\hline Sólidos dissolvidos & $\mathrm{mg} / \mathrm{L}$ & $<500$ & $500-2000$ & $>2000$ \\
\hline Manganês & $\mathrm{mg} / \mathrm{L}$ & $<0,1$ & $0,1-1,5$ & $>1,5$ \\
\hline Ferro & $\mathrm{mg} / \mathrm{L}$ & $<0,1$ & $0,1-1,5$ & $>1,5$ \\
\hline $\begin{array}{l}\text { Sulfeto de } \\
\text { hidrogênio }\end{array}$ & $\mathrm{mg} / \mathrm{L}$ & $<0,5$ & $0,5-2,0$ & $>2,0$ \\
\hline $\begin{array}{l}\text { População } \\
\text { bacteriana }\end{array}$ & $\begin{array}{l}\text { Número } \\
\text { máximo de } \\
\text { UFC* } / \mathrm{ml}\end{array}$ & $<10000$ & $10000-50000$ & $>50000$ \\
\hline
\end{tabular}

\subsection{Causas de entupimento em sistemas de irrigação por gotejamento}

Segundo Nakayama e Bucks (1991), são diversas as causas que podem provocar o entupimento parcial ou total de emissores e de tubulações, prejudicando o fluxo de água e sua distribuição ao longo das linhas de irrigação, principalmente nas laterais, e reduzindo a eficiência do sistema.

O entupimento pode ocorrer por diversas causas: areia, silte, argila, fitoplâncton (incluindo algas), zooplâncton, larvas e ovos de lesmas, bactérias, plástico (oriundo do corte de tubulações durante instalação e manutenção do sistema), raízes (para gotejamento subsuperficial), resíduos lubrificantes (oriundos por falta de manutenção adequada no conjunto moto-bomba), ação de bactérias (oxidando ferro, manganês e enxofre), precipitados (carbonato, fosfato, hidróxidos, ferro), uso de fertilizantes que aumentam a alcalinidade da água de irrigação e precipitação direta de substâncias químicas devido à mistura incompatível de fertilizantes (Nakayama \& Bucks, 1991 e Lopez et al., 1997).

Smajstrla (1995) relata que mesmo partículas muito pequenas como as de argila e organismos microscópicos como algas e algumas bactérias podem 
causar o entupimento no sistema de irrigação, por floculação e formação de partículas maiores ou precipitando íons. Este autor também relata que algumas bactérias, por oxidação de ferro dissolvido ou de sulfeto de hidrogênio, originam limos, que segundo Adin \& Sacks (1991) agem como surfatantes adesivos e facilitam a acumulação de argila, algas e outras partículas relativamente pequenas num mecanismo de entupimento gradual.

Gilbert et al. (1982) quantificaram e identificaram bactérias em água, gotejadores e tubulação, encontrando predominância de Pseudomonas stutzeri e Flavobacterium lutescens, capazes de oxidar ferro solúvel e formar limo.

Os princípios da formação de limos (também chamados de biofilmes) são detalhados por Kay et al. (1989), indicando que os mesmos desenvolvem-se facilmente com alto conteúdo de bactérias $(>10000 / \mathrm{ml})$, alta quantidade de sólidos em suspensão (> 100 ppm), presença de ferro e magnésio (> 1,5 ppm) e sólidos dissolvidos totais (> $2000 \mathrm{ppm}$ ). Resumidamente, todas as causas citadas estão compreendidas na combinação de material suspenso, na precipitação química e no crescimento biológico em bombas d'água, filtros, linhas de irrigação e emissores (Adin, 1986).

Scaloppi (1986) e Povoa \& Hills (1994) concordam que o entupimento de emissores está diretamente associado à qualidade da água de irrigação, a qual recebe diversas classificações. Entre elas está a contida na Tabela 3, desenvolvida por Bucks et al. (1979) e também apresentada por Pescod (1992) para sistemas de irrigação por gotejamento

\subsection{Susceptibilidade dos gotejadores ao entupimento}

Conforme Correa (1990), Keller \& Bliesner (1990), Pizarro (1996) e Lopez et al. (1997), são necessários diversos critérios para a seleção dos emissores. Dever-se-ia optar por emissores disponíveis comercialmente, relativamente de baixo custo, de pouca manutenção, de boa durabilidade e de 
boa uniformidade de distribuição. A susceptibilidade ao entupimento caracteriza-se como um dos fatores que interfere nestes critérios.

Atualmente existem diversos gotejadores em uso comercial. Cada tipo de emissor possui uma sensibilidade própria ao entupimento, fato que pode ser verificado em trabalhos realizados por Ravina et al. (1992) e Resende (1999 e 2003) e na classificação proposta por Pizarro (1996).

O pequeno diâmetro do orifício de gotejadores e a pequena velocidade da água $\left(<0,5 \mathrm{~m} \mathrm{~s}^{-1}\right)$ na passagem interna dos emissores favorecem 0 entupimento pelo crescimento biológico (Tajrishy et al., 1994 e Ravina et al., 1997).

Segundo Ravina et al. (1992), todos os gotejadores apresentam vulnerabilidade ao problema citado, pois geralmente apresentam passagens estreitas e aberturas pequenas (de 0,5 a $1,5 \mathrm{~mm}$ ). Gotejadores e microaspersores com diâmetros inferiores a 0,7 e a $0,4 \mathrm{~mm}$ são mais susceptíveis, e aqueles com diâmetros acima de 1,5 e 0,7 mm são menos susceptíveis, respectivamente (Lopez et al., 1997).

Estes autores também apontam a geometria da passagem como característica do emissor a ser considerada. Neste caso, são preferíveis: os gotejadores com menos zonas mortas no conduto de passagem, os não autocompensantes (pois os auto-compensantes reduzem a passagem à medida que se aumenta a pressão) e os de menor área exposta à evaporação.

Adequações na arquitetura ou no processo de fabricação dos gotejadores para a minimização de obstruções ocasionadas por intrusão radicular são sugeridos por Resende (2003). Contudo, esta sugestão pode ser extrapolada a outros tipos de entupimento.

Os emissores mais sensíveis são os constituídos por microtubos e os menos sensíveis são os auto-limpantes. Apesar disso Hills \& El-Ebaby (1990) verificaram ter ocorrido crescimento microbiano e conseqüente entupimento gradual, mesmo em gotejadores auto-limpantes, devido à deposição de impurezas orgânicas. 


\subsection{Técnicas para minimizar o entupimento}

Segundo Adin (1986), Chandrakanth et al. (1988), Adin e Elimelech (1989) e San Juan (1996), as águas residuárias apresentam diferentes qualidades durante o ano, estação, dia ou mesmo a cada hora. Portanto, diferentes procedimentos de tratamento devem ser usados, sejam eles físicos, químicos e/ou biológicos.

Diversas medidas podem ser adotadas, isoladas ou em conjunto, para prevenir a ocorrência de entupimento, tais como: o melhoramento do equipamento, o correto planejamento e manejo do sistema, a filtragem, a cloração, as descargas de água periódicas ao final das linhas de irrigação, o uso de hidrociclone, o uso de substâncias como o ácido sulfúrico, ácido fosfórico, ácido clorídrico, ácido peróxido acético, homopolímero de anidrido maleico, sais de cobre, amônia, ozônio e inibidores químicos adicionados ao material plástico dos emissores, tais como trifluralina e sulfato de cobre. Também podem ser utilizados a radiação ultravioleta, a piscicultura (reduzindo o conteúdo de partículas na água), os biofiltros (retirada de nitrogênio, fósforo, argila e algas em excesso), a aeração da água em lagoas (oxidação de ferro e manganês e volatilização de ácido sulfídrico antes de entrar no sistema) e a irrigação por vazão em pulsos (Oron et al., 1979; Gilbert \& Ford, 1986; Jackson \& Kay, 1987; Hills \& El-Ebaby, 1990; Meyer et al., 1991; Nakayama \& Bucks, 1991; Teltsch et al., 1991; Avnimelech et al., 1993; Diab et al., 1993; Schakschouk, 1996; Unkroth et al., 1997; Spooner et al., 1998; Hassen et al., 2000; Cararo et al., 2004).

A escolha de uma ou da combinação das medidas citadas deve ser cuidadosa, pois em certos casos pode ser ineficiente, dispendiosa, apresentar riscos à saúde humana ou causar resultados indesejáveis, como a fitotoxidez. Por outro lado, a geração de novas tecnologias preventivas é desejável.

Usualmente utilizam-se filtros combinados a um tratamento químico, inspeção a campo e lavagem das linhas laterais. Segundo Gilbert e Ford (1986), a filtragem e a inspeção a campo são absolutamente essenciais, e de 
acordo com Adin \& Sacks (1991), previnem o entupimento imediato por partículas relativamente grandes. A lavagem de linhas laterais e principais pode ajudar a minimizar o aumento de sedimentos e o tratamento químico pode melhorar a performance do sistema em longo prazo. Isto também foi constatado por Nakayama et al. (1978), que testaram cinco tratamentos durante dois anos, incluindo a combinação de diferentes filtros e tratamentos químicos intermitentes e contínuos.

\subsubsection{Filtragem}

Quando não há recomendações de fabricantes geralmente se adotam filtros que possuam malha filtrante com um décimo do menor diâmetro de abertura do emissor. Fabricantes recomendam os filtros de tela fina (100 a 200 mesh, equivalente à remoção de partículas com tamanho acima de 150 ou $75 \mu \mathrm{m}$, respectivamente).

Qualquer sistema de filtragem requer inspeção e limpeza rotineiramente para assegurar a operação satisfatória do sistema (Gilbert \& Ford, 1986). Segundo estes autores, os filtros de areia permitem inspeções menos constantes, mas podem fornecer condições favoráveis ao crescimento de bactérias e retém apenas partículas de 25 a $100 \mu \mathrm{m}$ (Gilbert \& Ford, 1986). Adin \& Elimelech (1989) constataram eficiências de 40 a $85 \%$ para filtros de areia com uso de água residuária, retirada de somente 1 a $2 \%$ do total de sólidos suspensos e entupimento muito rápido de filtros de tela.

Apesar da maior área para a retenção de partículas, os filtros de areia também podem entupir rapidamente, dependendo da quantidade de sólidos na água e da eficiência do filtro. Bralts (1986) demonstra como calcular essa eficiência de remoção de partículas, cujo cálculo pode ser generalizado para outros tipos de filtros. Cicero et al. (1997) somente obtiveram melhoras quanto ao entupimento dos emissores e quanto à redução da uniformidade de

distribuição de água quando utilizaram filtros de areia combinados com a cloração da água. 
Segundo Lopez et al. (1997) o funcionamento dos filtros de areia depende da qualidade da água, vazão (normalmente entre 50 e $70 \mathrm{~m}^{3} \mathrm{~h}^{-1}$ por $\mathrm{m}^{2}$ de filtrante, mas não superior a $70 \mathrm{~m}^{3} \mathrm{~h}^{-1}$ ), de uma queda máxima de pressão admitida de $60 \mathrm{kPa}$, da característica da areia (granulometria com peneiras de acordo com a norma ISO/R565, diâmetro efetivo de acordo com o tamanho da partícula a ser retida, coeficiente de uniformidade não superior a 1,6, calculada pela razão entre a abertura da malha filtrante que permite a passagem de $60 \%$ da areia e a abertura que permite a passagem de $10 \%$ da areia, no teste granulométrico; forma dos grãos preferencialmente arredondados, que proporciona maior microporosidade para retenção de partículas; boa friabilidade que proporciona boa resistência a ação mecânica; e perda por ataque com ácido inferior a $2 \%$, caracterizando a resistência química da areia), da altura mínima de areia $(40$ a $50 \mathrm{~cm}$ ) e das recomendações para limpeza, também descritas por estes autores.

O desempenho dos filtros de tela depende da vazão, da área efetiva de filtragem (malha entre 50 e 200 mesh) e de uma queda máxima de pressão admitida de $40 \mathrm{kPa}$.

Para os filtros de disco, a vazão, a espessura das ranhuras dos discos e a queda máxima de pressão de $40 \mathrm{kPa}$, são as variáveis mais influentes no funcionamento.

Barbagallo \& Buttafuoco (1998) testaram nove emissores com efluente de tratamento secundário (água residuária de origem municipal) e constataram que a filtragem melhorou a performance dos emissores comparada à lavagem da tubulação por descarga de água ao final da linha e ao aumento da pressão da água. Segundo estes autores as técnicas de descarga de água e de aumento de pressão não foram eficientes porque não limparam os emissores por completo.

No caso de águas residuárias, filtros de disco com malha superior a 120 mesh são mais sensíveis ao entupimento (Cicero et al., 1997), exigindo limpezas mais freqüentes e nem sempre operacionalmente possíveis. 


\subsubsection{Cloração}

Quanto a cloração por adição de hipoclorito de sódio, hipoclorito de cálcio ou gas cloro, Gilbert \& Ford (1986) afirmam ser basicamente um procedimento para controle da atividade microbiológica. Ao reagirem com a água, tais compostos originam ácido hipocloroso, que é mais eficiente no controle de bactérias (predominando em pH entre 5,0 e 6,0) e íon hipoclorito (predominando em pH acima de 7,5) $\left(\right.$ AWWA $^{2}$ e White ${ }^{3}$ citados por Resende, 1999). Portanto é interessante manter o pH da água abaixo de 7,0 .

Tajrishy et al. (1994) observaram que a adequada filtragem do efluente oriundo de tratamento secundário reduz a necessidade de cloração freqüente e de lavagem da linha lateral. Os mesmos autores verificaram similaridade entre a cloração intermitente com $2 \mathrm{mg} \mathrm{L}^{-1}$ de cloro residual livre durante a última hora do ciclo de irrigação e a cloração contínua com $0,4 \mathrm{mg} \mathrm{L}^{-1}$ de cloro residual livre, quanto à eficiência na prevenção da formação de biofilme nos emissores e rede distribuidora.

Rav-Acha et al. (1995) verificaram que $2 \mathrm{mg} \mathrm{L}^{-1}$ de $\mathrm{Cl}_{2}$ ou $\mathrm{ClO}_{2}$ causaram rápida inativação de bactérias, mas nem concentrações de $20 \mathrm{mg} \mathrm{L}^{-1}$ afetaram o número de células de algas, embora tenha reduzido sua capacidade de multiplicação e quantidade de clorofila.

Keller \& Bliesner (1990) propõem alguns valores indicativos de cloro para serem utilizados na prevenção de problemas que possam ocorrer como apresentados na Tabela 4. Apesar da existência dessas recomendações, Lopez et al. (1997) sugerem também o cálculo do pH, pois este afeta a eficiência do hipoclorito.

Verifica-se que em muitos casos o agente obstrutor é biológico, como relatado nos casos de uso de águas residuárias. Como medida usual, adota-se

\footnotetext{
${ }^{2}$ AMERICAN WATER WORKS ASSOCIATION. Água: (tratamento e qualidade). Rio de Janeiro: USAID, 1964. $465 \mathrm{p}$.

${ }^{3}$ WHITE, G.C. Handbook of chlorination. New York : Van Nostrand Reinhold, 1972. 744p.
} 
a cloração da água para prevenção a obstrução dos emissores. Segundo Ravina et al. (1992), esse tratamento é menos dispendioso e não há evidências de injúrias em raízes.

Tabela 4. Cloro residual livre para controle orgânico e de precipitados em sistemas de irrigação

\begin{tabular}{|c|c|c|}
\hline Forma de uso & Cloro & A controlar \\
\hline Contínua & 0,5 a $1 \mathrm{mg} \mathrm{L}^{-1}$ & Algas \\
\hline Aos 20 minutos finais da irrigação & $20 \mathrm{mg} \mathrm{L}^{-1}$ & Algas \\
\hline Não descrita & $\begin{array}{l}3,6 \text { a } 8,4 \text { vezes o } \\
\text { conteúdo de } \mathrm{H}_{2} \mathrm{~S}\end{array}$ & $\begin{array}{l}\text { Sulfeto de } \\
\text { hidrogênio }\end{array}$ \\
\hline Não descrita & $\begin{array}{l}1 \mathrm{mg} \mathrm{L}^{-1} \text { acima do } \\
\text { conteúdo de } \mathrm{Fe}\end{array}$ & Ferro-bactérias \\
\hline Não descrita & $\begin{array}{l}0,64 \text { vezes o } \\
\text { conteúdo de } \mathrm{Fe}^{2+}\end{array}$ & Ferro \\
\hline Não descrita & $\begin{array}{c}\text { 1,3 vezes o } \\
\text { conteúdo de } \mathrm{Mn}\end{array}$ & Manganês \\
\hline Manutenção ao final das linhas de irrigação & $1 \mathrm{mg} \mathrm{L}^{-1}$ & Limo \\
\hline
\end{tabular}

Nakayama et al. (1977) obtiveram sucesso utilizando hipoclorito e ácidos, porém Schischa et al. (1997) verificaram que embora tivessem controlado o entupimento pelo uso de cloração, o uso de grandes quantidades de cloro prejudicou a capacidade de regulagem de vazão e pressão das membranas elásticas dos emissores.

Outra limitação é alertada por Macedo et al. (1983) é a formação de trihalometanos (THMs) na reação de cloro com produtos dissolvidos na água de irrigação. Os THMs (triclorometano ou clorofórmio, bromodiclorometano, iodobromoclorometano, dibromoclorometano, tribromometano ou bromofórmio) podem ser absorvidos pelas plantas e posteriormente, transferidos ao ser humano, no qual se caracterizam como agentes potencialmente cancerígenos.

Deve-se também considerar a tolerância das culturas a cloretos como sugerem os valores indicados de níveis máximos permissíveis por cultura 
apresentados por Ayers \& Westcot (1999). Entretanto, de acordo com Gilbert \& Ford (1986) as fontes de cloro utilizadas em baixas concentrações possivelmente não causem prejuízos às plantas.

\subsubsection{Combinação entre filtragem e cloração}

Ravina et al. (1997) trabalharam com diversos emissores utilizados em Israel e com água residuária, constatando que a aglomeração de finas partículas e o crescimento da biomassa microbiológica no interior das linhas de irrigação iniciou-se em emissores ao final das linhas laterais, sendo mais comum nos que possuíam menores vazões. A solução adotada pelos autores foi a utilização de filtro de 80 mesh combinado com cloração diária e abertura do final das linhas a cada dois meses.

Barbagallo \& Buttafuoco (1998) usando efluente de tratamento secundário de esgoto municipal, notaram que a performance dos gotejadores foi melhor usando a filtragem, e que a cloração não influenciou muito o resultado, assim como os aumentos de pressão de água e a lavagem de sedimentos das tubulações não limparam os emissores completamente.

Entretanto, Al-Nakshabandi et al. (1997) estudaram metais pesados e coliformes fecais em plantas de berinjela irrigadas com água residuária sob irrigação localizada, e observaram um entupimento relativamente pequeno no sistema sem o uso de filtros. Esses autores justificam o sucesso do controle à aplicação de ácido e cloro.

Em adição, segundo Adin \& Sacks (1991), a filtragem previne o entupimento imediato por partículas relativamente grandes e com formas irregulares, ao passo que a modificação interna dos emissores e o prétratamento com oxidantes e floculantes, reduzem o potencial da água ao entupimento. 


\subsubsection{Ar comprimido}

Devido ao problema de resistência e potenciais impactos ambientais, pesquisadores como Cloete (2003) comentam sobre a necessidade de estratégias alternativas para controlar biofilmes em sistemas de distribuição de águas em indústrias. No caso da agricultura, também se procuram métodos menos agressivos ao ambiente, ao sistema de irrigação e aos seres humanos.

Um processo alternativo de prevenção do entupimento é o uso de ar comprimido, o qual é um processo físico que possibilitaria a secagem dos emissores e como ação mecânica, retiraria partículas em suspensão e/ou partes da biomassa de agentes biológicos presentes próximos aos gotejadores. A secagem dos emissores seria importante, pois a água é um elemento essencial à sobrevivência e ao crescimento microbiológico.

Watanabe \& Metsugi (1979) haviam mencionado, em patente, o uso da técnica de ar comprimido. Eles descreveram que o processo de limpeza seria utilizando uma fonte de ar comprimido que por paradas temporárias do suprimento de água, o ar seria introduzido na tubulação utilizando-se de um compressor localizado próximo ao conjunto moto-bomba. A pressão utilizada foi $300 \mathrm{kPa}$ durante 10 minutos. O resultado foi a recuperação da vazão dos emissores. Contudo, os emissores eram pequenos cortes na tubulação, diferente do equipamento em uso atualmente. Além disso, pode haver dificuldade em manter e distribuir uniformemente a pressão utilizada por Watanabe \& Metsugi (1979) em sistemas de irrigação para grandes áreas.

Keller \& Bliesner (1990) indicam a pressão de ar de 490 a $980 \mathrm{kPa}$ no início das linhas de irrigação, com a finalidade de expulsar a mucilagem depositada ao longo da tubulação. Para isto, o sistema deve suportar tal pressão e, além disso, podem ocorrer deformações na tubulação ou nos próprios emissores, causando excessos de vazão nestes.

Hills \& Brenes (2001) comentaram que ocorreram mudanças na elasticidade do material de alguns gotejadores fabricados por reentrâncias 
delgadas na tubulação de polietileno, aplicando efluente tratado. Fato este também constatado por Watanabe \& Metsugi (1979), mas com aplicação de ar comprimido. Portanto, procura-se uma pressão que possibilite a prevenção à obstrução do sistema, minimizando o entupimento biológico, químico ou físico, e que não altere as características do emissor. Assim como a pressão, não há muitas informações a respeito da vazão de ar a ser utilizado.

Portanto, mais estudos são necessários, pois além das possíveis vantagens quanto à prevenção de entupimentos, a aplicação de ar tem como vantagens não gerar resíduos químicos e riscos ao produtor ou ao consumidor dos alimentos produzidos. 


\section{MATERIAL E MÉTODOS}

Este trabalho foi conduzido em três etapas, sendo uma em laboratório e as outras duas em campo. Na primeira caracterizou-se os gotejadores novos, na segunda definiu-se o grau de sensibilidade dos gotejadores ao entupimento e na terceira, definiu-se a melhor combinação de manejo e modelo de gotejador para a minimização do entupimento.

\subsection{Caracterização dos gotejadores novos}

Nesta etapa realizaram-se as determinações da vazão, do coeficiente de variação de vazão, da uniformidade de distribuição e da curva vazão versus pressão de 15 modelos de gotejadores.

\subsubsection{Localização e período dos ensaios}

Os ensaios foram conduzidos no Laboratório de Hidráulica do Departamento de Engenharia Rural pertencente a ESALQ / USP, em Piracicaba - SP. Esta etapa foi desenvolvida no segundo semestre de 2001.

\subsubsection{Modelos de gotejadores amostrados}

Selecionaram-se 15 modelos de gotejadores existentes no mercado nacional, utilizando-se os mais comercializados segundo os fabricantes, embora ocorra uma variação em relação às regiões e às culturas em que o sistema é 
implantado. Entre os selecionados estão emissores auto-compensantes, não auto-compensantes de fluxo turbulento, planos, cilíndricos, inseridos e moldados, abrangendo dessa forma uma amostra representativa de emissores existentes no comércio. Contudo, alguns modelos em uso não foram incluídos por apresentar problemas de uniformidade, defeitos de fabricação ou dificuldades na aquisição.

Os modelos amostrados foram: Dripln PC (A), Ram (B), Hydro PC (C), Hydrogol (D), Dripln Classic (E), Agrazud (F), Carbodrip (G), GFT (H), Naan Paz (I), Hydrodrip II (J), Aquatraxx (K), Goldendrip (L), Chapin (M), Azudline (N) e Streamline (O). Os espaçamentos dos emissores na linha gotejadora, bem como as vazões e diâmetros de tubulação foram adotados conforme a disponibilidade comercial.

$\mathrm{Na}$ Figura 1 visualiza-se os tipos de gotejadores testados, quanto à forma e o sistema de funcionamento. A classificação adotada foi: gotejadores não auto-compensantes cilíndricos ("tipo bob") e internos (modelos D, E, F e G); não auto-compensantes, planos, internos, com pré-filtro e labirinto retilíneos e curtos (modelos $\mathrm{J}, \mathrm{N}$ e O); não auto-compensantes, planos, internos, com préfiltro e labirinto tortuosos (modelos I e L), não auto-compensantes, planos, internos com pré-filtro e labirinto retilíneos e longos (modelos $\mathrm{K}$ e $\mathrm{M}$ ); não autocompensantes com labirinto circular em disco e externos (modelo $\mathrm{H}$ ); autocompensantes planos e internos (modelo $B$ ); e auto-compensantes cilíndricos e internos (modelos A e C). A Tabela 5 apresenta outras características destes emissores.

Tecnicamente, os catálogos de alguns emissores deixam a desejar. A falta de dados como o coeficiente de variação, as características inerentes às dimensões da passagem de água pelo emissor, os diâmetros internos de tubulação e a espessura de tubulações, podem dificultar a escolha de emissores em projetos. 


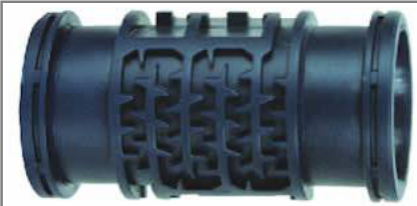

Não auto-compensantes cilíndricos e internos

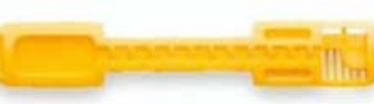

Não auto-compensantes, planos, internos, com pré-filtro e labirinto retilíneos e curtos

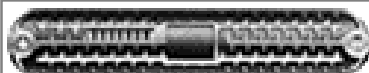

Não auto-compensantes, planos, internos, com pré-filtro e labirinto tortuosos

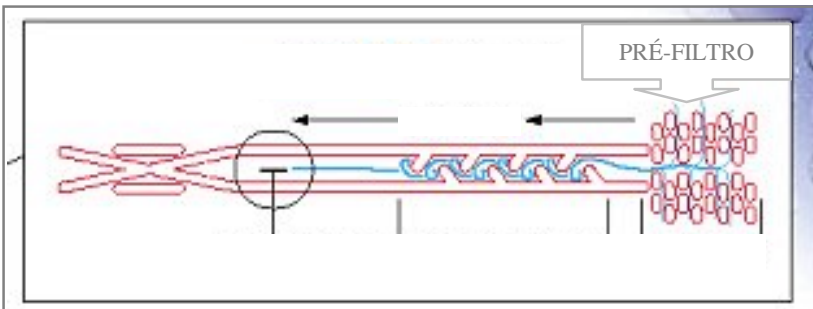

Não auto-compensantes, planos, internos com pré-filtro e labirinto retilínio e longo

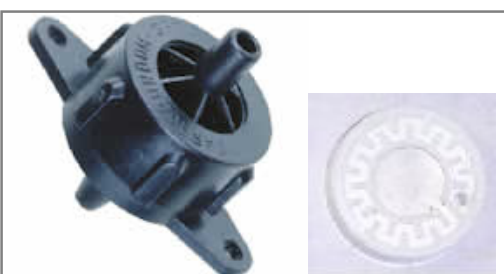

Não auto-compensantes com labirinto circular em disco e externos
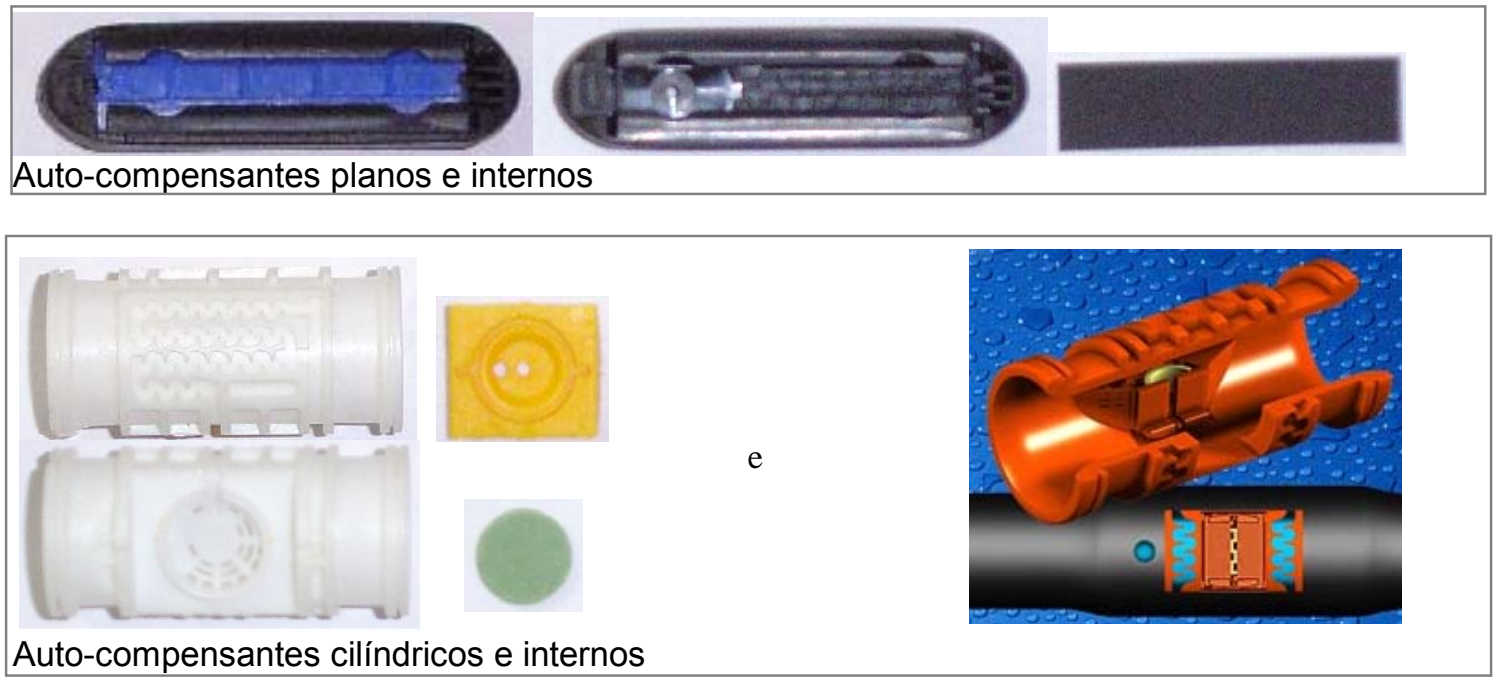

Figura 1 - Tipos de gotejadores conforme o sistema de funcionamento e forma 
No caso deste trabalho, os espaçamentos entre emissores, os diâmetros internos, as espessuras de parede das tubulações, e as dimensões das passagens de água no interior do emissor, apresentados na Tabela 5, foram em sua maioria medidos no material adquirido. Assim como a vazão, o coeficiente de variação de vazão e a curva de vazão e pressão foram obtidos em laboratório.

Tabela 5. Características dos gotejadores testados de acordo com o espaçamento entre emissores $\left(E_{e}\right)$, vazão de catálogo a pressão de $98 \mathrm{kPa}\left(\mathrm{V}_{\mathrm{c}}\right)$, coeficiente de variação de vazão em catálogo $\left(\mathrm{CV}_{\mathrm{c}}\right)$, comprimento de passagem de água $\left(\mathrm{C}_{\mathrm{p}}\right)$, seção de passagem mais estreita $\left(S_{e}\right)$, profundidade da passagem de água $\left(P_{p}\right)$, espessura da parede da tubulação $\left(E_{t}\right)$ e diâmetro interno da tubulação $\left(D_{t}\right)$

\begin{tabular}{ccccccccc}
\hline $\begin{array}{c}\text { Modelo de } \\
\text { gotejador }\end{array}$ & $\begin{array}{c}\mathrm{E}_{\mathrm{e}} \\
(\mathrm{cm})\end{array}$ & $\begin{array}{c}\mathrm{V}_{\mathrm{c}} \\
\left(\mathrm{L} \mathrm{h}^{-1}\right)\end{array}$ & $\begin{array}{c}\mathrm{CV}_{\mathrm{c}} \\
(\%)\end{array}$ & $\begin{array}{c}\mathrm{C}_{\mathrm{p}} \\
(\mathrm{mm})\end{array}$ & $\mathrm{S}_{\mathrm{e}}$ & $\begin{array}{c}\mathrm{P}_{\mathrm{p}} \\
(\mathrm{mm})\end{array}$ & $\begin{array}{c}\mathrm{E}_{\mathrm{t}} \\
(\mathrm{mm})\end{array}$ & $\begin{array}{c}\mathrm{D}_{\mathrm{t}} \\
(\mathrm{mm})\end{array}$ \\
\hline $\mathrm{A}$ & 75 & 2,29 & $\leq 5 \%$ & 135 & 1,0 & 0,8 & 1,00 & 16,0 \\
$\mathrm{~B}$ & 65 & 1,60 & $\mathrm{NI}{ }^{*}$ & 30 & 1,0 & 0,8 & 0,90 & 14,2 \\
$\mathrm{C}$ & 80 & 2,00 & $\leq 4$ & 126 & 0,8 & 0,8 & 1,14 & 16,0 \\
$\mathrm{D}$ & 40 & 2,20 & $\leq 5$ & 200 & 1,0 & 0,8 & 1,00 & 13,8 \\
$\mathrm{E}$ & 50 & $\mathrm{NI}$ & 1,4 & 170 & 1,0 & 1,0 & 1,00 & 12,0 \\
$\mathrm{~F}$ & 60 & 2,30 & $\mathrm{NI}$ & 314 & 1,0 & 1,0 & 1,00 & 16,0 \\
$\mathrm{G}$ & 50 & 2,20 & $\mathrm{NI}$ & 140 & 1,0 & 1,0 & 0,85 & 13,8 \\
$\mathrm{H}$ & 30 & 2,30 & $\mathrm{NI}$ & 70 & 0,8 & 0,8 & 1,00 & 16,0 \\
$\mathrm{I}$ & 75 & 1,70 & $\leq 3$ & 155 & 0,6 & 0,8 & 0,85 & 16,0 \\
$\mathrm{~J}$ & 60 & 1,70 & $\leq 5$ & 45 & 1,0 & 0,8 & 0,80 & 15,2 \\
$\mathrm{~K}$ & 60 & $1,40^{* *}$ & $\mathrm{NI}$ & 250 & 1,0 & 0,4 & 0,50 & 15,9 \\
$\mathrm{~L}$ & 30 & $1,70^{* * *}$ & $\leq 5$ & 105 & 0,8 & 0,8 & 0,38 & 16 \\
$\mathrm{M}$ & 20 & $\mathrm{NI}$ & $\mathrm{NI}$ & 175 & 0,8 & 0,8 & 0,45 & 16 \\
$\mathrm{~N}$ & 30 & $\mathrm{NI}$ & $\leq 5$ & 100 & 1,0 & 0,8 & 0,30 & 16 \\
$\mathrm{O}$ & 20 & 1,05 & $\mathrm{NI}$ & 175 & 0,4 & 0,5 & 0,20 & 16 \\
\hline \\
* valor não indicado pelo fabricante \\
** para 67,6 kPa \\
*** para 117,6 kPa
\end{tabular}




\subsubsection{Descrição da montagem para realização dos ensaios laboratoriais}

Efetuou-se a montagem da bancada de testes para cada modelo de gotejador ensaiado. Cada instalação constou de duas tubulações de polietileno com 25 emissores numerados e com barbantes para o desvio das gotas de água aos coletores. As tubulações foram unidas no início e ao final por conexões de PVC e sustentadas a $20 \mathrm{~cm}$ sobre provetas de $250 \mathrm{~mL}$.

Utilizou-se também um registro de agulha, uma válvula reguladora de pressão, uma tomada de pressão com manômetro no início das tubulações, um filtro de disco de 120 mesh para retirar partículas de diâmetro superior a $130 \mu \mathrm{m}$ e um de tela de 450 mesh para retirada de partículas de diâmetro superior a $22 \mu \mathrm{m}$, além de balança com precisão de $0,01 \mathrm{~g}, 50$ garrafas plásticas cortadas para transferência dos volumes coletados e cronômetro. A Figura 2 mostra o sistema montado e a bancada de pesagem.

Optou-se pelo uso de filtros devido à presença de sólidos em suspensão visualmente detectáveis na água do laboratório (partículas acima de 0,1 mm). Foi utilizada uma válvula reguladora de pressão para reduzir a oscilação de pressão na tubulação, a qual foi de $\pm 3 \mathrm{kPa}$, detectada quando se tentou utilizar somente o registro de agulha. 


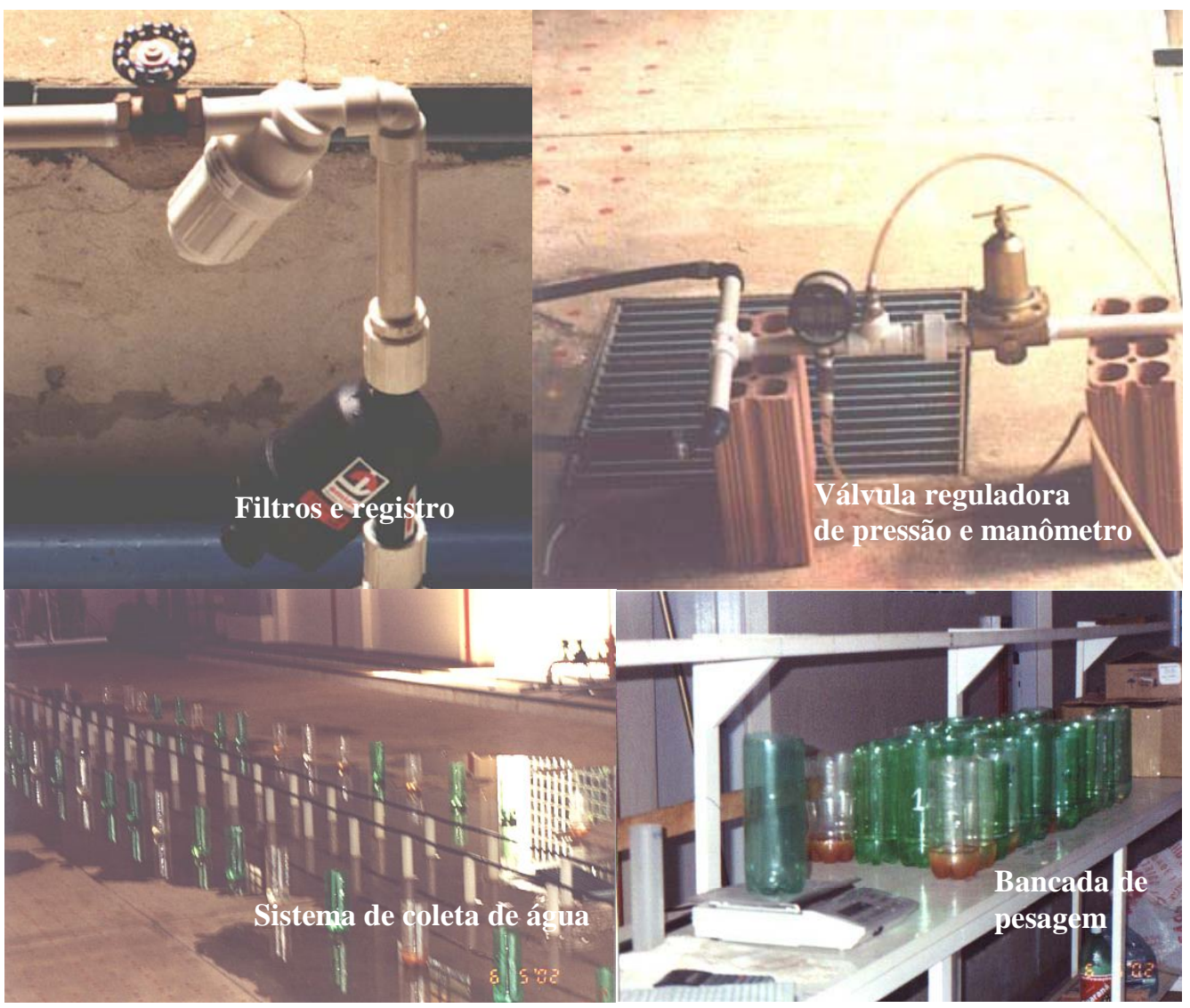

Figura 2 - Instalação utilizada para realizar os ensaios laboratoriais

\subsubsection{Ensaio para a determinação da vazão, do coeficiente de variação de fabricação e da uniformidade de distribuição}

O ensaio foi realizado coletando água de 50 gotejadores durante 10 minutos em três repetições, com temperatura da água de aproximadamente $27^{\circ} \mathrm{C}$.

Optou-se por ensaiar tubulações gotejadoras utilizando o espaçamento comercializado e não separar os gotejadores para o ensaio em bancada, evitando diferenças relacionadas à influência de emendas e da proximidade dos emissores, adotando assim condições semelhantes a dos irrigantes. Isto concorda com Resende (1999), o qual sugere o uso de tubo-gotejadores com espaçamento apropriado para reduzir erros e representar melhor a condição real para sistemas de irrigação. 
A necessidade de execução das leituras por apenas uma pessoa conduziu o procedimento de ensaio a uma metodologia específica. O procedimento consistiu da pressurização do sistema, estabilização da pressão em $98 \mathrm{kPa}$ no início das linhas, posicionamento das provetas sob os respectivos gotejadores com uma defasagem de 5 segundos, transferência de volumes para garrafas plásticas com colocação imediata de outra proveta no local da primeira, retirada seqüencial das provetas após 10 minutos com defasagem de 5 segundos, transferência do volume restante das provetas para as garrafas plásticas, transporte das garrafas à bancada de pesagem, pesagem e tabulação dos dados.

O procedimento descrito foi adotado a cada tubulação contendo 25 emissores, devido ao número limitado de provetas. Assim, repetia-se o procedimento para a outra tubulação, a fim de se obter a vazão dos 50 emissores para cada modelo ensaiado. Depois de tabulados os pesos, efetuaram-se os cálculos da vazão, do coeficiente de variação de fabricação e da uniformidade de distribuição pelas equações numeradas de (1) a (3).

$$
\mathrm{q}_{\text {novo }}=\frac{\mathrm{P}}{1000 \mathrm{t}} 60
$$

em que,

$$
\begin{aligned}
& \text { Gnovo - vazão do gotejador novo, } \mathrm{L} \mathrm{h}^{-1} \text {; } \\
& P \text { - peso da água coletada, g; e } \\
& \mathrm{t} \quad \text { - tempo de coleta, min. } \\
& C V_{f}=\frac{s_{\text {novo }}}{\bar{q}_{\text {novo }}} 100
\end{aligned}
$$

em que,

$\mathrm{CV}_{f}$ - coeficiente de variação da fabricação, \%;

Snovo - desvio padrão da vazão dos gotejadores novos, $\mathrm{L} \mathrm{h}^{-1}$; e

$\bar{q}_{\text {novo }}$ - vazão média do gotejador novo, $L h^{-1}$. 


$$
U D=\frac{q_{25 \%}}{q_{\text {média }}} 100
$$

em que,

UD - uniformidade de distribuição, \%;

$\mathrm{q}_{25 \%}$ - vazão média de $1 / 4$ do menores valores, $\mathrm{L} \mathrm{h}^{-1}$; e

$\mathrm{q}_{\text {média }}$ - vazão média, $\mathrm{L} \mathrm{h}^{-1}$.

\subsubsection{Ensaio para a determinação da curva vazão versus pressão}

Uma vez definida a vazão de cada gotejador para cada modelo, selecionou-se uma amostra de 10 emissores para o ensaio, os quais correspondiam às menores variações de vazão em relação à média.

Adotou-se o mesmo procedimento utilizado para o ensaio de vazão, sendo amostrados os 10 gotejadores anteriormente selecionados ao invés de 50 , para 6 pressões definidas dentro da faixa de uso de cada modelo e mostradas em catálogo, as quais foram: 50, 100, 150, 200, 250 e $300 \mathrm{kPa}$ para os modelos de gotejador A, B, C, E, F, G, H, I e N; 30, 44, 58, 72, 86 e 100 para o modelo K; 40, 60, 80, 100, 120 e 140 para os modelos M e L; e 50, 75, 100, 125,150 e 175 para os modelos $\mathrm{D}, \mathrm{J}$ e $\mathrm{O}$.

Utilizaram-se garrafas plásticas para a coleta da água, mantendo-se as linhas gotejadoras sustentadas sobre provetas a $20 \mathrm{~cm}$ do nivel do solo. Dessa forma foi possível a coleta, com uma defasagem de 10 segundos, de todos os emissores em um único ensaio para cada modelo.

Efetuaram-se três repetições dos ensaios e posteriormente confeccionaram-se as curvas "vazão versus pressão" em planilha eletrônica, obtendo as respectivas equações dos emissores por regressão. 


\subsection{Estudo da susceptibilidade dos gotejadores ao entupimento}

Nesta etapa conduziu-se um experimento a campo a fim de se determinar o coeficiente de variação da vazão e o grau de entupimento dos emissores provenientes da fase anterior. $O$ objetivo desta etapa foi definir 0 grau de sensibilidade dos modelos ao entupimento, a fim de viabilizar a etapa seguinte.

\subsubsection{Localização e período da segunda etapa}

Esta etapa foi conduzida na Estação de Tratamento de Esgoto da Bacia do Rio Piracicamirim (ETE), pertencente ao Serviço Municipal de Água e Esgoto de Piracicaba - SEMAE, durante o primeiro semestre de 2002.

$\mathrm{O}$ esgoto ao ser coletado e ao chegar a ETE, passa pelo processo de lodo ativado na seguinte estrutura, seqüencialmente: peneira, tanque de gordura, reator anaeróbio, lagoa aerada, decantador, aeradores em degrau e Ribeirão Piracicamirim. O tempo total de detenção do esgoto na estação é de 22 horas, a vazão média de saída do efluente é de $0,2 \mathrm{~m}^{3} \mathrm{~s}^{-1}$.

\subsubsection{Descrição e montagem do sistema de irrigação}

O sistema foi composto por válvula de pé, bomba centrífuga, filtros de areia, disco e tela, hidrômetro, registro de agulha, válvula ventosa, linhas gotejadoras (correspondentes aos modelos anteriormente ensaiados), tomadas de pressão e acessórios de PVC. O cabeçal de controle foi instalado depois dos decantadores da ETE e as linhas gotejadoras foram dispostas em área gramada, em declive, conforme mostrado nas Figuras 3 e 4. 


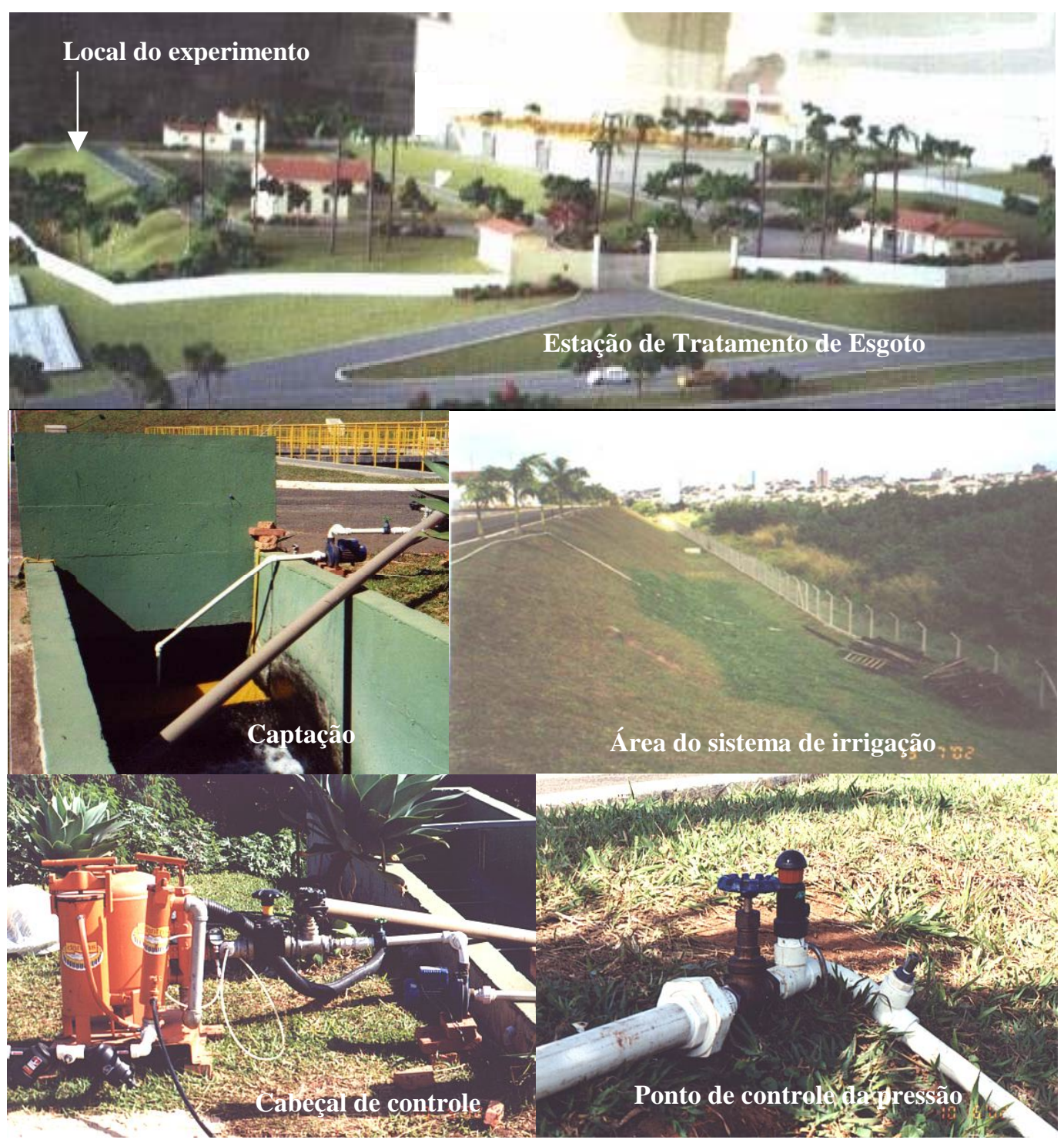

Figura 3 - Instalação utilizada para o estudo da sensibilidade dos gotejadores ao entupimento 


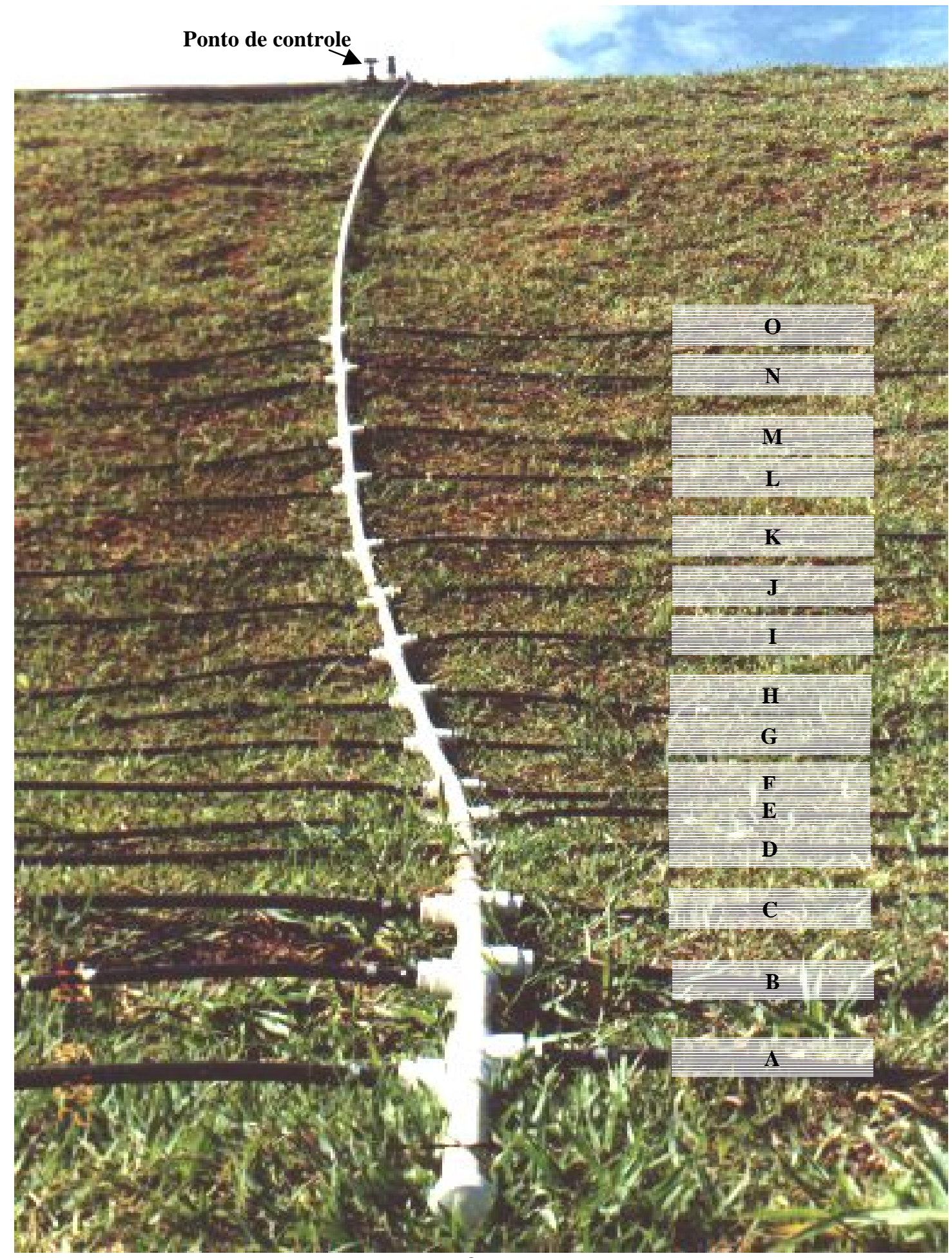

Figura 4 - Posição das tubulações referentes a cada modelo de gotejador na linha de derivação e ponto de controle de pressão com registro de agulha 
Usou-se uma bomba centrífuga marca KSB, modelo C 500 cuja curva, obtida do fabricante, está mostrada na Figura 5.

A areia do filtro necessitou ser trocada por outra cujas características são descritas na Tabela 6, principalmente devido ao fato da primeira não apresentar a retenção de sólidos desejada, ou seja, ser ineficiente na retenção de partículas com tamanho superior a $75 \mu \mathrm{m}$. Assim, em função da malha de filtragem recomendada comercialmente, adotou-se um diâmetro efetivo de areia correspondente a 200 mesh (máxima filtragem requerida pelos emissores em teste) e com grãos mais uniformes. Tal uniformidade (1,08 \%), está de acordo com Lopez et al. (1997), os quais relatam que o coeficiente de uniformidade da areia não pode ultrapassar $1,6 \%$. No caso da areia contida no filtro, inicialmente a mesma apresentava, pelo teste granulométrico, 41,22 \% de areia com diâmetro de 1,19 a 1,99 mm, 13,32 \% com diâmetro de 1,18 a $1 \mathrm{~mm} e$ 34,48 \% com diâmetro de 0,99 a $0,59 \mathrm{~mm}$, fato que ocasionou o maior coeficiente. A profundidade da camada filtrante foi de $40 \mathrm{~cm}$, valor também recomendado pelos mesmos autores.

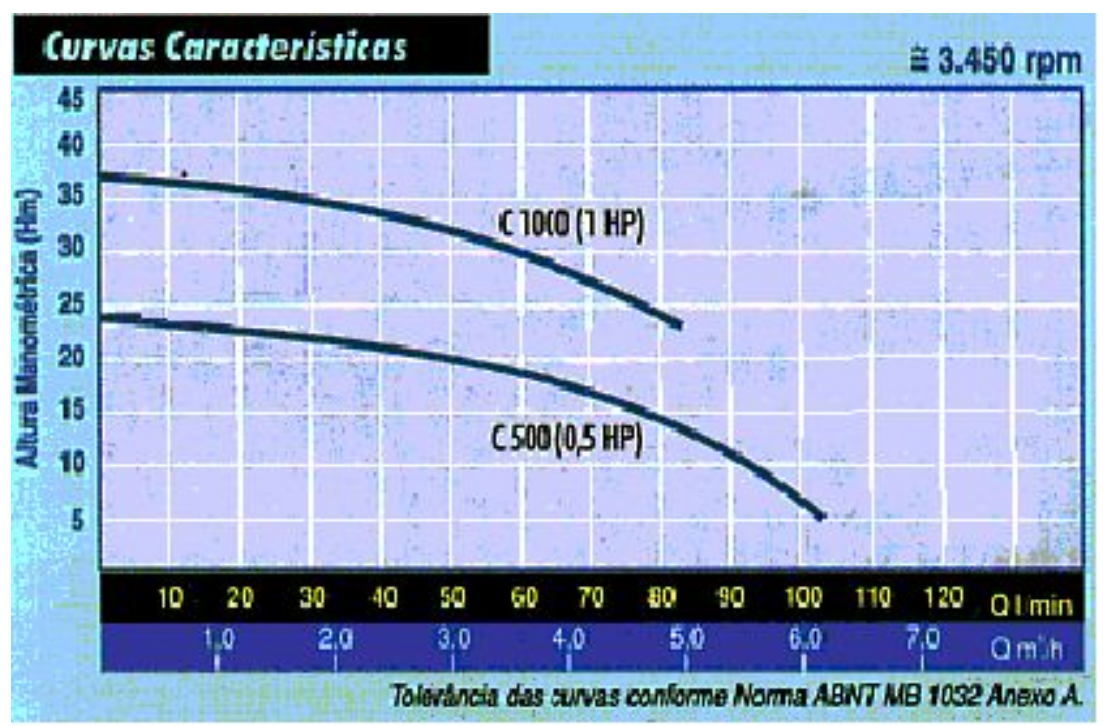

Figura 5 - Curvas características de bombas de água centrífugas, marca KSB, utilizadas no experimento (C 500 e C 1000) 
Tabela 6. Diâmetro efetivo $\left(D_{e}\right)$, resistência mecânica $\left(R_{m}\right)$, resistência química $\left(R_{q}\right)$, forma dos grãos $\left(F_{g}\right)$ e coeficiente de uniformidade da areia utilizada $\left(\mathrm{CU}_{\mathrm{a}}\right)$

\begin{tabular}{cccccc}
\hline Areia & $\begin{array}{c}\mathrm{D}_{\mathrm{e}} \\
(\mathrm{mm})\end{array}$ & $\mathrm{R}_{\mathrm{m}}$ & $\mathrm{R}_{\mathrm{q}}$ & $\mathrm{F}_{\mathrm{g}}$ & $\begin{array}{c}\mathrm{CU}_{\mathrm{a}} \\
(\%)\end{array}$ \\
\hline Antes da troca & 0,59 & Boa & Resistente & Anguloso & 2,04 \\
Depois da troca & 0,59 & Muito boa & Resistente & Arredondado & 1,08 \\
\hline Determinação das características : Lopez et al. (1997) & & &
\end{tabular}

Adotou-se uma malha de 120 mesh para o filtro de disco, a fim de prevenir possíveis entupimentos do sistema com areia.

Utilizaram-se dois filtros de tela de 200 mesh em paralelo, sendo um com diâmetro nominal de $25,4 \mathrm{~mm}$ e outro com $38,1 \mathrm{~mm}$, colocados para melhorar a eficiência de filtragem e aumentar o tempo entre retrolavagens.

As tomadas de pressão foram dispostas após o registro da bomba de água, após o filtro de areia, após o filtro de disco, após os filtros de tela e após o registro de agulha para controle manual da pressão, também chamado de ponto de controle. O registro de agulha foi escolhido ao invés da válvula reguladora de pressão, para reduzir perdas de carga no sistema.

As linhas foram dispostas em campo de forma que os modelos autocompensantes ficassem nas posições inferiores do terreno, visto que os mesmos requerem maiores pressões para um bom funcionamento, enquanto que as tubulações gotejadoras com paredes delgadas foram dispostas em posições superiores no terreno. Para esta disposição houve necessidade de se realizar um levantamento de cotas e dispor as tubulações gotejadoras em nível utilizando-se um nível de mangueira. Distribuiu-se uma tubulação com 25 emissores para cada lado da linha de derivação, totalizando 50 gotejadores de cada modelo. 


\subsubsection{Qualidade da água residuária}

Fez-se a coleta de uma amostra de água do local de captação, antes da sucção da bomba d'água, para efeito de caracterização. As características da mesma estão apresentadas nas Tabelas 7 e 8. As análises foram realizadas por laboratórios especializados em Piracicaba e na ETE da Bacia do Ribeirão Piracicamirim.

Tabela 7. Demanda bioquímica de oxigênio (DBO), degradação química de oxigênio (DQO), sólidos totais (ST), sólidos suspensos (SS), sólidos dissolvidos (SD), alcalinidade total (maioria carbonato) (AT), nitrogênio total $(\mathrm{N})$, fosfato $\left(\mathrm{PO}_{4}\right)$, oxigênio dissolvido $(\mathrm{OD})$ da água residuária utilizada no primeiro semestre de 2002

\begin{tabular}{|c|c|c|c|c|c|c|c|c|}
\hline DBO & DQO & ST & SS & SD & AT & $\mathrm{N}$ & $\mathrm{PO}_{4}$ & OD \\
\hline & 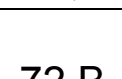 & & & $\left.\mathrm{L}^{-1}\right)$ & $M$ & ת & DM & DM \\
\hline
\end{tabular}

Letras após os números indicam os níveis baixo (B), baixo a médio (BM) e médio a alto (MA) segundo Pescod (1992) para águas residuaria oriunda de esgoto doméstico

Tabela 8. Potencial hidrogeniônico $(\mathrm{pH})$, coliformes totais $(\mathrm{CT})$, coliformes fecais $(\mathrm{CF})$, turbidez e temperatura $(\mathrm{T})$ da água residuária utilizada no primeiro semestre de 2002

\begin{tabular}{|c|c|c|c|c|}
\hline \multirow{2}{*}{$\mathrm{pH}$} & CT & CF & \multirow{3}{*}{$\begin{array}{c}\text { Turbidez } \\
\text { (UNT) } \\
4 \mathrm{~B}\end{array}$} & \multirow{3}{*}{$\begin{array}{c}\mathrm{T} \\
\left({ }^{\circ} \mathrm{C}\right) \\
22 \mathrm{~N}\end{array}$} \\
\hline & (NN & & & \\
\hline $7 \mathrm{M}$ & $7040 \mathrm{~A}$ & $3200 \mathrm{~A}$ & & \\
\hline
\end{tabular}

\subsubsection{Aplicação da água residuária}

Conduziu-se a aplicação da água residuária durante 373 horas, conforme mostrado na Figura 6. Usualmente, as aplicações iniciavam-se às 4 horas e 30 minutos e terminavam às 16 horas e 30 minutos, controlando-se a partida da bomba por um temporizador.

O entupimento diário de filtros exigiu paradas de aproximadamente 20 minutos, para limpeza. Ocorreram outras paradas pelos seguintes motivos: limpeza da parte do sistema antes dos filtros, troca de areia, instalação de filtro 
de tela adicional e hidrômetro, substituição de ventosa, troca de regulador de pressão por registro de agulha, falta de água potável para a limpeza de filtros e problema na vedação do filtro de areia, entre outras.

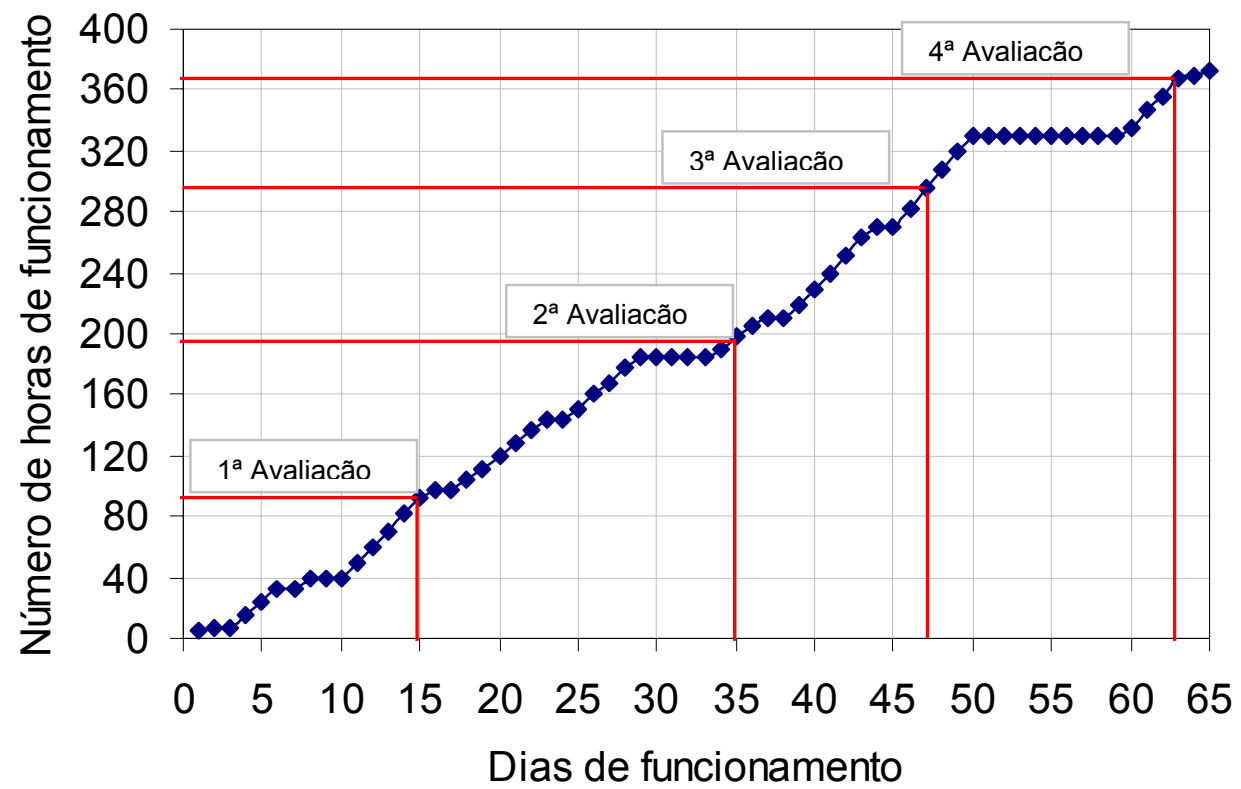

Figura 6 - Número de horas de funcionamento do sistema de irrigação com aplicação da água residuária e avaliações de vazão realizadas

O sistema permaneceu desligado em períodos necessários à limpeza dos filtros, em feriados, domingos e parte dos sábados, em função do horário de funcionamento da ETE e da presença de responsáveis pelo gerenciamento da mesma.

As limpezas consistiram da retrolavagem do filtro de areia com água potável, limpeza do filtro de disco e dos filtros de tela. Inicialmente, estabeleceuse que a partir do momento em que a pressão no ponto de controle reduzisse $1 \mathrm{kPa}$, haveria necessidade da limpeza. Entretanto, posteriormente admitiu-se uma variação de $\pm 10 \%$ na pressão. Assim, pode-se ter maior flexibilidade para regular o registro de agulha para dentro desta faixa de variação, diminuindo-se o número de limpezas e proporcionando maior tempo de funcionamento a cada dia. 
Todos os modelos de gotejadores funcionaram na faixa de pressão definida nas curvas vazão versus pressão. Verificou-se por cálculos que eram necessários $65 \mathrm{kPa}$ no ponto de controle (início da linha de derivação) para manter as pressões no início das linhas gotejadoras dentro da faixa de operação. Assim, para a pressão de $65 \mathrm{kPa}$, calculou-se trecho a trecho, as pressões para cada modelo instalado na área experimental, conforme mostradas na Tabela 9, utilizando a equação característica de cada emissor e a de Hazen-Williams para cálculo da perda de carga a cada trecho. Como as linhas de cada modelo (duas por modelo de gotejador) foram mantidas na mesma cota topográfica, considerou-se a mesma pressão para ambas. Outra consideração, comprovada por cálculos, foi a de que a pressão ao longo das laterais ou na entrada dos emissores era a mesma obtida no início da linha, pois de acordo com a pequena vazão na linha (máxima de $68 \mathrm{~L} \mathrm{~h}^{-1}$ ) e o pequeno comprimento de linha (máximo de $20 \mathrm{~m}$ ), a perda de carga total na linha foi pequena $(0,38 \mathrm{kPa}$ para a tubulação diâmetro interno igual a $12 \mathrm{~mm})$.

Tabela 9. Desníveis geométricos médios em relação ao cabeçal de controle e pressões médias no início das linhas gotejadoras, calculadas para 65 $\mathrm{kPa}$ no ponto de controle

\begin{tabular}{ccc}
\hline Modelo de gotejador & Desnível $(\mathrm{m})$ & Pressão $(\mathrm{kPa})$ \\
\hline A & 4,84 & 109,45 \\
B & 4,75 & 108,58 \\
C & 4,67 & 107,83 \\
D & 4,58 & 106,91 \\
E & 4,46 & 105,85 \\
F & 4,35 & 104,90 \\
G & 4,20 & 103,59 \\
H & 4,03 & 102,19 \\
I & 3,88 & 101,08 \\
J & 3,59 & 98,74 \\
K & 3,39 & 97,24 \\
L & 3,11 & 95,26 \\
M & 2,82 & 92,80 \\
N & 2,40 & 92,64 \\
O & 2,16 & 91,26 \\
\hline
\end{tabular}




\subsubsection{Avaliações de vazão}

Durante 0 experimento, foram realizadas três avaliações a aproximadamente $1 / 3,2 / 3$ e final de cada tubulação gotejadora, em amostras de seis gotejadores por modelo com 97, 198 e $300 \mathrm{~h}$ de funcionamento, e uma avaliação ao final do experimento, com todos os 50 gotejadores de cada modelo e $373 \mathrm{~h}$ de funcionamento. As três avaliações iniciais foram realizadas com seis pessoas, uma para cada emissor, com cada modelo de gotejador, em três repetições e com cinco minutos de coleta. A coleta de água foi feita com provetas de $250 \mathrm{ml}$ com precisão de $2 \mathrm{ml}$, previamente comparadas ao método da pesagem. A última avaliação consistiu da coleta de água de 25 em 25 emissores, também com cinco minutos para coleta. A pressão em todos os ensaios ficou a $65 \mathrm{kPa}$ no ponto de controle, podendo variar $\pm 10 \%$.

A coleta de água foi realizada de forma seqüencial, colocando as linhas (quatro) sobre os coletores e deixando os mesmos sob os gotejadores (previamente identificados e com barbantes amarrados na tubulação para desviar as gotas de água dos gotejadores para os coletores), em linhas alternadas e em direção ao aclive, no tempo de coleta de cinco minutos. Após este tempo, realizaram-se as leituras dos volumes coletados. Posteriormente iniciou-se a colocação de outras quatro linhas sucessivamente, do modelo A ao modelo $\mathrm{O}$.

Com os dados de volume foi possível efetuar os cálculos de vazão, coeficiente de variação de vazão e do grau de entupimento dos gotejadores, pelas equações numeradas de (4) a (6).

$$
\mathrm{q}_{\text {usado }}=\frac{\mathrm{V}}{1000 \mathrm{t}} 60
$$

em que,

$$
\begin{array}{ll}
\text { qusado } & \text { - vazão do gotejador usado, } \mathrm{L} \mathrm{h}^{-1} ; \mathrm{e} \\
\mathrm{V} & - \text { volume de água coletada, } \mathrm{mL} .
\end{array}
$$




$$
\mathrm{CV}_{\mathrm{q}}=\frac{\mathrm{s}_{\text {usado }}}{\mathrm{q}_{\text {usado }}} 100
$$

em que,

$\mathrm{CV}_{\mathrm{q}} \quad$ - coeficiente de variação da vazão, \%; e

S usado - desvio padrão da vazão dos gotejadores usados, $\mathrm{L} \mathrm{h}^{-1}$.

$$
G E=\left(1-\frac{q_{\text {usado }}}{\bar{q}_{\text {novo }}}\right) 100
$$

em que,

GE - grau de entupimento, \%.

\subsubsection{Seleção dos emissores}

A susceptibilidade dos gotejadores foi definida baseando-se no grau de entupimento e no coeficiente de variação de vazão dos mesmos. Os gotejadores que apresentaram maiores graus de entupimento e coeficiente de variação foram classificados como mais susceptíveis ao entupimento e viceversa.

Análises de probabilidade simples, utilizando o software KaleidaGraph, também auxiliaram na escolha dos modelos. Para isto, considerou-se emissores com bom desempenho aqueles que se encontravam na faixa de variação de vazão aceitável de $\pm 5 \%$ da vazão dos emissores quando usados em relação aos mesmos quando novos. Como exemplo, considere-se a Figura 7, na qual o modelo D apresenta como limites os valores 95 e 40, os quais correspondem a 95 \% de probabilidade de encontrar emissores com vazão inferiores ou iguais a 1,05 vezes a vazão dos mesmos quando novos e $40 \%$ de probabilidade de encontrar emissores com vazão inferior a 0,95 vezes a vazão dos mesmos quando novos. Obtendo-se a diferença entre esses valores, tem-se que o modelo D apresenta $55 \%$ de probabilidade de encontrar emissores na faixa hachurada e considerada na análise de probabilidade. 


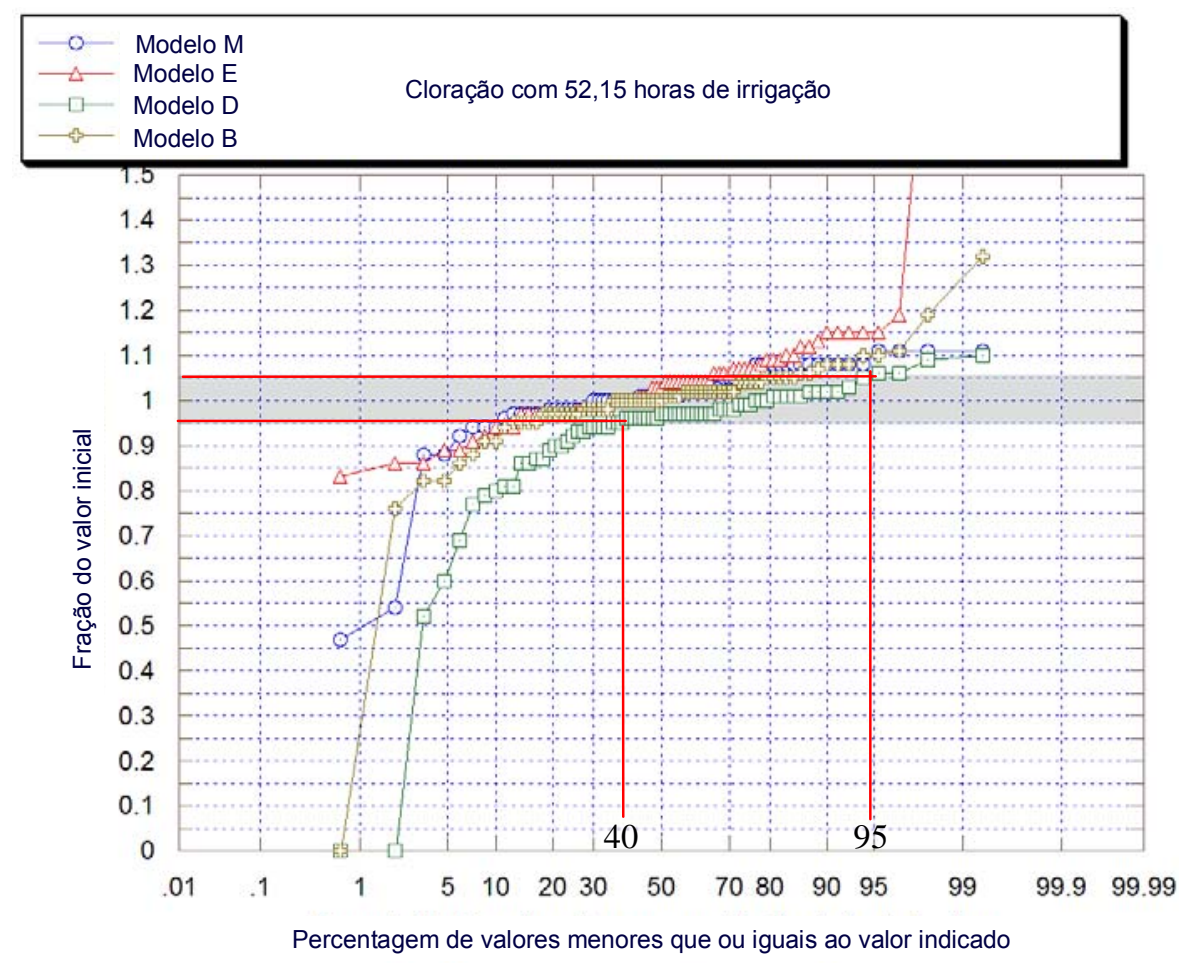

Figura 7 - Gráfico para exemplificação da análise probabilística de vazão utilizada na segunda e terceira etapas deste trabalho

Portanto, de acordo com o coeficiente de variação de vazão, o grau de entupimento e a análise probabilística de vazões, selecionaram-se quatro modelos para a terceira etapa, sendo os dois mais e os dois menos susceptíveis.

\subsubsection{Visualização do entupimento pelo uso de água residuária}

Após a finalização do experimento foram abertos alguns gotejadores, os quais apresentaram alto grau de entupimento. Usando uma máquina fotográfica foi possível registrar o biofilme que ocasionou a redução da vazão. Na grande maioria dos gotejadores houve dificuldade em se efetuar a abertura sem influenciar a posição da obstrução no interior do emissor. Em alguns modelos não houve possibilidade de se efetuar a abertura devido ao fato dos gotejadores estarem moldados à tubulação (modelos K e M). 


\subsection{Estudo dos manejos preventivos ao entupimento}

Foi efetuada a aplicação de quatro tipos de manejo. As avaliações de vazão indicaram o grau de entupimento e o coeficiente de variação, os quais definiram as melhores e piores combinações de modelo de gotejador e manejo. Análises probabilísticas também auxiliaram nesta definição.

\subsubsection{Localização e período da terceira etapa}

Este experimento foi conduzido em uma área do Departamento de Produção Vegetal, pertencente à Escola Superior de Agricultura "Luiz de Queiroz"- ESALQ / USP, localizada ao lado da ETE da Bacia do Ribeirão Piracicamirim, de agosto de 2002 a agosto de 2003. O delineamento experimental foi adotado o de parcelas subdivididas, com 4 tipos de manejos (parcela), 4 modelos de gotejadores (subparcela) e 3 repetições (linhas de irrigação/modelo).

\subsubsection{Modelos de gotejadores selecionados}

Nesta etapa foram utilizados os dois menos susceptíveis (B e D) e os dois mais susceptíveis ( $E$ e $M$ ) modelos de gotejadores oriundos da segunda etapa. Os melhores gotejadores foram analisados visando viabilizar a irrigação com a água residuária utilizada e testar os diferentes manejos de desentupimento. $\mathrm{O}$ uso dos piores gotejadores visou acentuar os problemas e permitir, assim, estudar o manejo mais eficaz contra o entupimento. 


\subsubsection{Descrição e montagem do experimento}

Esta fase, executada durante o segundo semestre de 2002, consistiu da aquisição de material e instalação do sistema de irrigação no campo.

Depois de se efetuar a medição das distâncias, desnível geométrico, construção de abrigo para o cabeçal de controle, solicitação e ligação de energia elétrica até o abrigo e solicitação de fornecimento de efluente pela ETE, iniciou-se a instalação hidráulica.

O sistema foi composto de tubulações de captação de $50,8 \mathrm{~mm}$ após os degraus de oxigenação da ETE, de um reservatório com capacidade de $500 \mathrm{~L}$, bóias de água com diâmetro nominal de 50,8 mm cada, duas bombas centrífugas dispostas em série (KSB- C 1000 e KSB - C 1000N, cujas curvas estão apresentadas nas Figuras 5 e 8), filtros (os mesmos utilizados na segunda etapa), tomadas de pressão, registros de precisão, uma bomba após os filtros (KSB - C 500), tanque de fertirrigação adaptado para aplicação de solução clorada, compressor de ar tipo "TUFÃO" (bombeamento por ação de diafragma, com valores máximos de pressão de $275 \mathrm{kPa}$ e de vazão de $2 \mathrm{~L} \mathrm{~s}^{-1}$ ), hidrômetros para leitura dos volumes de água e de solução clorada aplicados, adutora de polietileno de $20 \mathrm{~mm}$, linhas de distribuição de $16 \mathrm{~mm}$, tubulações gotejadoras novas, acessórios em PVC e polietileno, cronômetro, manômetro e kit de ortolidina para determinação da concentração de cloro residual livre. 


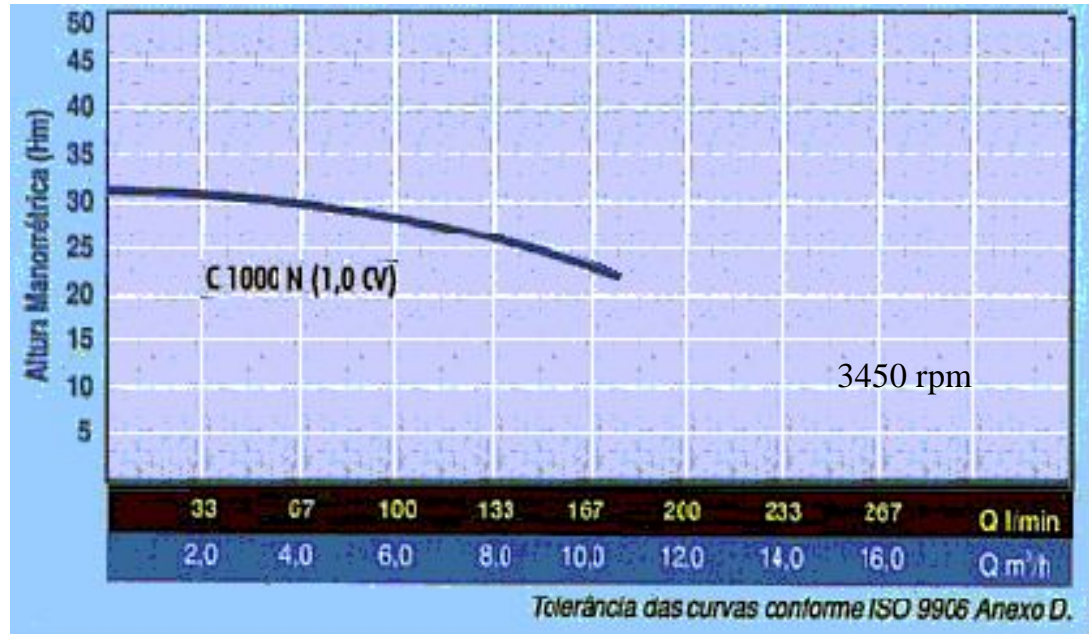

Figura 8 - Curva característica de bomba de água centrífuga, marca KSB, utilizada no experimento (C 1000N)

O croqui apresentado na Figura 9 mostra a disposição do sistema, instalado em um pomar de tangerina cv. Ponkan, com duas linhas de distribuição por linha de plantas, sendo três linhas de irrigação por modelo para cada manejo. Fotos do sistema hidráulico podem ser visualizados na Figura 10.

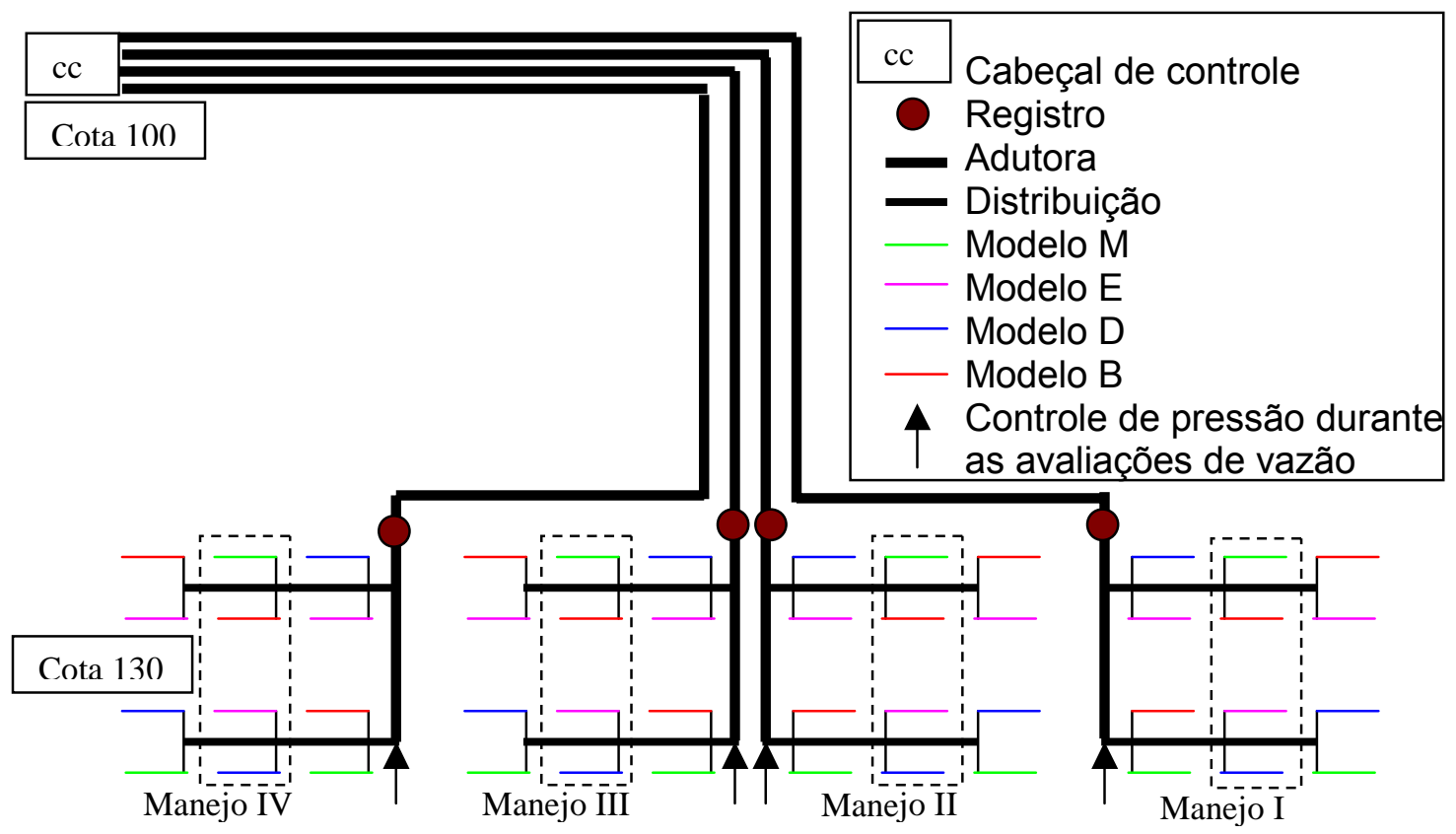

Figura 9 - Croqui da instalação hidráulica a campo para seleção dos manejos preventivos ao entupimento (terceira etapa do trabalho) 


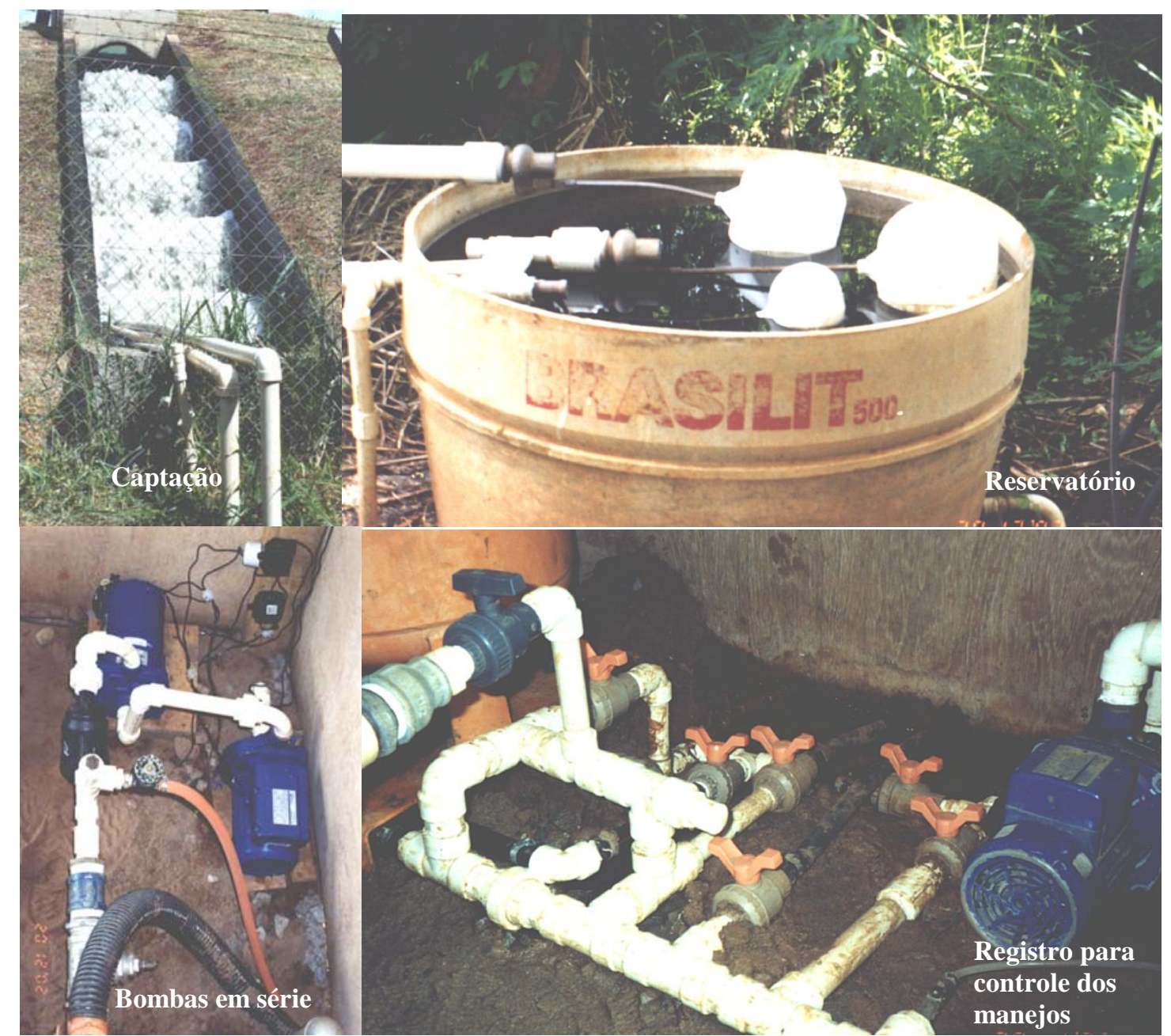

Figura 10 - Cabeçal de controle para o estudo dos modelos de gotejador versus manejos preventivos ao entupimento (terceira etapa do trabalho)

O sistema foi dimensionado utilizando o teorema de Bernoulli, a equação de Flammant para o cálculo das perdas de carga na tubulação (diâmetro interno das tubulações menor que $50 \mathrm{~mm}$ ), o método do comprimento equivalente para o cálculo das perdas de carga localizadas e a vazão dos gotejadores novos, correspondentes aos mesmos lotes dos ensaiados na primeira etapa, com exceção do gotejador modelo B. Foi necessário adquirir este modelo novamente, pois não havia material suficiente para a instalação. Devido a isto, foram realizados novos ensaios de curva vazão versus pressão para o novo lote do modelo B (após a segunda etapa), cujo espaçamento entre emissores foi $75 \mathrm{~cm}$ e vazão média a $98 \mathrm{kPa}$ foi $1,61 \mathrm{~L} \mathrm{~h}^{-1}$. 
As linhas de irrigação foram instaladas em comprimentos iguais a $5 \mathrm{~m}$ (modelo M), 10 m (modelo D), 12 m (modelo E) e 18 m (modelo B). Distribuiu-se o sistema em 48 linhas, com 25 emissores cada, totalizando, assim, 1200 gotejadores divididos em 12 linhas por modelo e três linhas por modelo em cada manejo. Quatro adutoras de $940 \mathrm{~m}$ com diâmetro de $20 \mathrm{~mm}$ conduziram a água e $\mathrm{o}$ ar aos respectivos tratamentos. Este comprimento de adutora foi necessário, pois o pomar de tangerina, o qual se irrigava, estava distante da fonte de água residuária. Além disso, a distância utilizada permitiu a reação do cloro às substâncias presentes na água no tempo correspondente a 15 minutos.

\subsubsection{Manejos preventivos ao entupimento}

Esta parte do estudo, iniciada em fevereiro de 2003, constou da aplicação de quatro tipos de manejo preventivo ao entupimento, quais sejam: I) controle (sem manejo preventivo além de filtragem); II) aplicação de solução de água residuária com cloro ao final da irrigação; III) aplicação de ar comprimido entre as irrigações; e IV) aplicação de água residuária com cloro ao final da irrigação e ar comprimido entre as irrigações (II + III).

A respeito dos tipos de manejo, também se pode mencionar o seguinte: o tratamento I é o padrão, também chamado controle, sem injeção de produtos para prevenção ao entupimento. Em todos os tratamentos foram utilizados os mesmos filtros de areia, de disco e de tela estabelecidos no cabeçal de controle.

Os filtros foram dispostos junto ao conjunto moto-bomba e aos registros de controle dos tratamentos, permitindo melhor controle manual das retrolavagens no filtro de areia, limpeza dos demais filtros e subseqüente ajuste da pressão no cabeçal de controle para a irrigação requerida.

No manejo II ocorreu a aplicação de $50 \mathrm{~L}$ de hipoclorito de sódio (10\%) na dosagem de $20 \mathrm{mg} \mathrm{L}^{-1}$ de cloro, nos 15 minutos finais da irrigação a cada dia de aplicação de solução clorada. Sendo dividido 25 L para cada tipo de manejo 
(II e IV). As aplicações foram feitas a cada irrigação e a concentração atingida na saída dos emissores ao final da tubulação gotejadora foi de $0,5 \mathrm{mg} \mathrm{L}^{-1}$ de cloro residual livre. $\mathrm{O}$ volume de $25 \mathrm{~L}$ de solução clorada corresponde ao volume interno da tubulação gotejadora que recebia o tratamento.

A dosagem de solução clorada foi ajustada a $20 \mathrm{mg} \mathrm{L}^{-1}$ pela checagem de $0,5 \mathrm{mg} \mathrm{L}^{-1}$ de cloro residual livre no gotejador mais distante. Esta concentração foi baseada no princípio de que todo cloro reage com compostos presentes na água, incluindo a ação sobre bactérias formadoras de biofilme. A pequena concentração restante $\left(0,5 \mathrm{mg} \mathrm{L}^{-1}\right)$, representa apenas uma margem de segurança residual das reações. Outros motivos da escolha dessa concentração foram a baixa possibilidade de ocorrência de fitotoxidez e o menor custo em aquisição do produto clorado. A concentração utilizada também foi baseada nas referências de Keller \& Bliesner (1990) e Tajrishy et al. (1994), os quais também sugerem concentrações relativamente baixas, como $2 \mathrm{mg} \mathrm{L}^{-1}$ intermitentemente e $1 \mathrm{mg} \mathrm{L}^{-1}$ ou $0,4 \mathrm{mg} \mathrm{L}^{-1}$ continuamente.

Utilizou-se 15 minutos para a aplicação do produto químico, pois correspondia ao tempo de deslocamento do mesmo até o final das linhas de irrigação. Nesse tempo, permitia-se que as reações com a amônia e com os compostos orgânicos, de ferro e de enxofre ocorressem. Acredita-se que esse tempo foi suficiente para a ocorrência destas reações, pois Lopez et al. (1997) a maior parte dos virus e bactérias são inativados de 10 a 30 minutos de contato e em pesquisas desenvolvidas na Estação de Tratamento de Esgoto em Lins, Estado de São Paulo, utilizou-se tempos de contato do cloro similares $(15 \text { minutos })^{4}$ com propósitos de desinfecção. Além disso, a presença de acessórios na tubulação tais como curvas, tês, registros e reduções, e o regime turbulento na adutora auxiliam na mistura do hipoclorito de sódio à água e conseqüentemente auxiliaram nas reações com as substâncias presentes na água, permanecendo ao final o cloro residual livre na forma de $\mathrm{OCl}^{-} \mathrm{e} / \mathrm{ou} \mathrm{HOCl}^{-}$, de acordo com o $\mathrm{pH}$. 
O manejo III consistiu da adição de ar no interior da tubulação à pressão de 1,96 kPa. O ar foi introduzido nas linhas gotejadoras durante os períodos em que o sistema não estava sendo utilizado para irrigar, visando secar os gotejadores, dificultando desta forma o desenvolvimento de algas, fungos e bactérias e também expulsando os sólidos.

A indisponibilidade de energia elétrica próxima às parcelas de manejo de ar comprimido, conduziu a instalação do compressor junto ao cabeçal de controle. Com isso, houve redução de pressão em relação a pressão inicial do compressor devido ao desnível geométrico $(30 \mathrm{~m})$ e perdas na tubulação e emissores, restando apenas a pressão de 1,96 kPa na entrada dos gotejadores (medida no final da linha de irrigação pelo uso de piezômetro). Uma solução para este problema seria usar um compressor de maior pressão, porém usualmente este é de elevado custo de aquisição. O interessante seria a instalação próxima às parcelas, economizando energia, porém, em virtude do mencionado anteriormente, isto não foi possível.

Outro item a relatar é que se seguiu a hipótese de que mesmo à baixa pressão o objetivo de minimização poderia ser alcançado; o que foi considerado fundamental foi permitir a chegada do ar aos emissores. Assim, baseado nesses fatores, e ainda considerando que o ar é aproximadamente 700 vezes mais leve que a água, escolheu-se o compressor disponível no comércio que permitisse alta vazão mas a baixa pressão em comparação aos existentes, bem como aquele que fosse de baixa amperagem $(3,5 \mathrm{~A})$, pois funcionaria por longos períodos, sendo importante a economia de energia elétrica cedida pela ETE da Bacia do Ribeirão Piracicamirim.

A vazão de ar foi limitada ao modelo de gotejador, correspondendo em maiores vazões em emissores como o modelo B (emissor com característica de alta vazão quando membrana elástica não está em funcionamento, ou seja, a baixa pressão) e $D$ (emissor com maior vazão de água entre os testados). As vazões de ar variaram de duas a sete vezes a vazão nominal de água dos

\footnotetext{
${ }^{4}$ MENDONÇA, F. C. Doutor em Agronomia : Irrigação e Drenagem - Informação pessoal 2004.
} 
emissores. As vazões de ar foram medidas pelo processo volumétrico utilizando uma proveta com água, cronometrando-se o tempo para coletar-se $200 \mathrm{ml}$ de ar que ocupava o espaço da água no interior da proveta.

O manejo IV combinou a ação dos manejos II e III, com o propósito de efetuar uma melhor prevenção ao entupimento, como sugerido em literatura.

\subsubsection{Execução dos tipos de manejo propostos}

Quando indicado o momento de irrigar, efetuava-se seqüencialmente: a troca de água do reservatório, a retrolavagem manual do filtro de areia, a pressurização do sistema, o enchimento do tanque de cloro, a irrigação inicial, a injeção da solução clorada nos manejos II e IV e a irrigação final.

A troca de água do reservatório anterior às bombas teve a finalidade de disponibilizar a água para a irrigação na mesma qualidade que esta era lançada pela ETE. Isto se justifica em função da permanência da água residuária no reservatório causar alterações à sua qualidade devido à atividade microbiológica e à sedimentação de sólidos que ocorrem no intervalo entre as irrigações. Pelo mesmo motivo retirou-se a água residuária retida no interior da tubulação condutora presente antes das bóias.

Para a retrolavagem do filtro de areia (utilizado na segunda etapa) foi utilizada a própria água residuária, porém adicionou-se um filtro de tela de 200 mesh antes do filtro de areia, com a finalidade de minimizar a entrada de sólidos na parte inferior da camada filtrante. Quando a água de saída permanecia relativamente clara, retirava-se esse filtro de tela para evitar perdas de carga desnecessárias durante a irrigação e cessava-se a retrolavagem.

Estando o sistema pressurizado, começava-se a contagem do tempo de irrigação, cujo valor acumulado encontra-se na Figura 11. O tempo inicial foi calculado pela equação (7). O tempo final era o tempo para a reação e transporte do cloro aos gotejadores (15 minutos). O tempo de injeção de solução clorada variou de 2 a 5 minutos. O tempo de injeção de cloro era 
também acrescido ao tempo de irrigação dos manejos I e III, evitando diferenças no tempo de aplicação de água residuária entre os tratamentos.

$$
\mathrm{Tii}=\mathrm{Ti}-\mathrm{Tif}-\mathrm{Tic}
$$

em que,

$$
\begin{array}{ll}
\text { Tii } & \text { - Tempo inicial, min; } \\
\text { Ti } & \text { - Tempo de irrigação, min; } \\
\text { Tif } & \text { - Tempo de irrigação final, min; e } \\
\text { Tic } & \text { - Tempo de aplicação da solução clorada, min. }
\end{array}
$$

No dia seguinte à irrigação efetuava-se o esvaziamento de todas as tubulações por aberturas no cabeçal de controle e em locais sujeitos a permanência de água na adutora. Depois de completada a drenagem ligava-se o compressor de ar que trabalhava controlado por um temporizador em intervalos de 30 minutos, em nove operações a cada dia, enviando ar para os manejos III e IV. Este procedimento foi efetuado diariamente até que se indicasse o momento de irrigar. A Figura 11 também mostra o tempo acumulado de ar aplicado.

Optou-se pelo funcionamento em intervalos de 30 minutos para evitar aquecimento demasiado do compressor e para seguir as recomendações do fabricante, e nove operações porque foi o número máximo permitido pelo temporizador. 


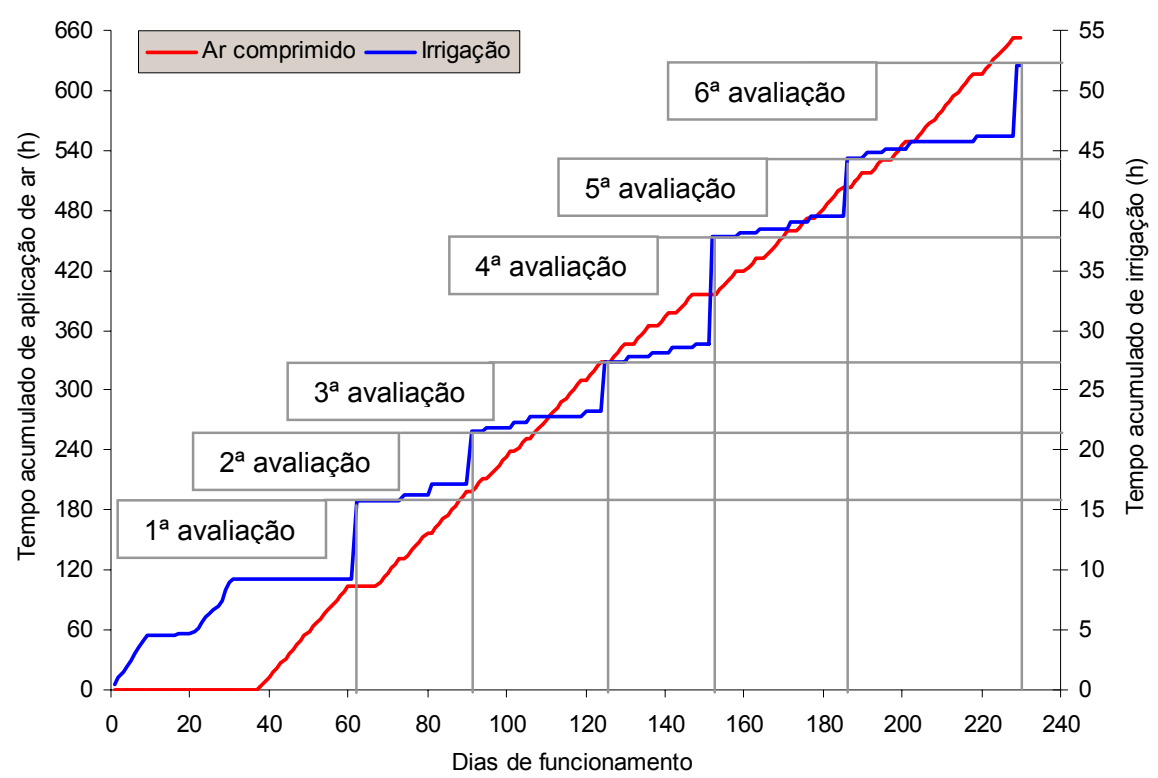

Figura 11 - Tempos de funcionamento do sistema de irrigação e de ar comprimido utilizados na terceira etapa, e momentos em que se efetuaram as avaliações de vazão

\subsubsection{Irrigação}

Irrigou-se no período da manhã dos dias para irrigação, uma área ocupada por 108 plantas, no espaçamento $6 \mathrm{~m} \times 4 \mathrm{~m}$.O manejo da irrigação foi baseado no balanço hídrico da cultura de citros e a quantidade de água, calculada com o método evaporimétrico do tanque Classe "A", utilizando-se as equações (8) e (9), e a eficiência do sistema de irrigação igual a 90 \%. Quando a diferença entre a somatória das evapotranspirações diárias e a disponibilidade real de água no solo atingia uma lâmina correspondente superior ao tempo de 20 minutos (tempo para o transporte e injeção da solução clorada), efetuava-se a irrigação, de forma que o solo atingisse a umidade correspondente à capacidade de campo. 


$$
\mathrm{ET}_{\mathrm{c}}=\mathrm{Ev} \mathrm{K}_{\mathrm{p}} \mathrm{K}_{\mathrm{c}} \mathrm{K}_{\mathrm{r}}
$$

em que,

$$
\begin{aligned}
& \mathrm{ET}_{\mathrm{c}} \text { - evapotranspiração da cultura, } \mathrm{mm} \mathrm{dia}^{-1} \text {; } \\
& \text { Ev - evaporação do tanque classe "A", } \mathrm{mm} \text { dia }{ }^{-1} \text {; } \\
& K_{p} \text { - coeficiente do tanque classe "A", adimensional; } \\
& \mathrm{K}_{\mathrm{c}} \quad \text { - coeficiente da cultura, adimensional; e } \\
& \mathrm{K}_{\mathrm{r}} \text { - coeficiente de redução para irrigação localizada. } \\
& \mathrm{T}_{\mathrm{i}}=\frac{\sum E \mathrm{~T}_{\mathrm{c}} \mathrm{S}_{\mathrm{l}} \mathrm{L}}{\mathrm{q} \mathrm{n}_{\mathrm{l}} \mathrm{g}_{\mathrm{l}}} 60
\end{aligned}
$$

em que,

$\mathrm{S}_{\mid} \quad$ - espaçamento entre duas linhas gotejadoras, $\mathrm{m}$;

$\mathrm{L} \quad$ - comprimento da parcela correspondente a um manejo, $\mathrm{m}$;

q - vazão média de todos os gotejadores, $\mathrm{L} \mathrm{h}^{-1}$;

$\mathrm{n}_{\mathrm{l}} \quad$ - número de linhas gotejadoras em um manejo, adimensional; e

$g_{l} \quad$ - número de gotejadores por linha de irrigação.

O Kp utilizado foi 0,85 (Bernardo, 1995). Este valor foi obtido a partir da velocidade de vento inferior a $175 \mathrm{~km} \mathrm{~d}^{-1}$ e umidade relativa entre 40 e $70 \%$, valores estes característicos do local. O Kc utilizado foi 0,90 (Doorenbos e Kassam, 1979). Este valor foi obtido para uma cultura de citros, em situação de máxima demanda hídrica e sem controle de plantas invasoras. O Kr utilizado foi 0,35 . Este valor corresponde ao valor proposto por Keller e Karmelli, descritos por Vermeiren e Jobling (1997) para um grau de cobertura da área pela cultura de $30 \%$.

A vazão média dos gotejadores foi recalculada a cada avaliação de vazão efetuada. O tempo de irrigação foi calculado em função de um único tratamento, pois os demais receberam a mesma quantidade de água e todos foram irrigados simultaneamente.

Para o cálculo da disponibilidade real de água no solo na capacidade de campo (DRA = 20,5 mm) use utilizou a equação (10). 


$$
\mathrm{DRA}=\frac{\left(U_{\mathrm{cc}}-U_{\mathrm{pmp}}\right)}{10} \mathrm{~d}_{\mathrm{s}} \mathrm{Zp}
$$

em que,

DRA - disponibilidade real de água no solo, $\mathrm{mm}$;

$\mathrm{U}_{\mathrm{cc}} \quad$ - umidade na capacidade de campo, \% peso;

$U_{\text {pmp }}$ - umidade no ponto de murcha permanente, \% peso;

$\mathrm{d}_{\mathrm{s}} \quad$ - densidade do solo, $\mathrm{g} \mathrm{cm}^{-3}$;

Z - profundidade efetiva do sistema radicular, $\mathrm{cm}$; e

$\mathrm{p} \quad$ - fator de disponibilidade de água no solo, adimensional.

A umidade na capacidade de campo utilizada foi de $9,92 \%$ em base de peso, a umidade no ponto de murcha foi de $6,78 \%$ em base de peso, a densidade do solo foi $1,63 \mathrm{~g} \mathrm{~cm}^{-3}$. Além destes dados, obtidos a partir de Medeiros (1987), utilizou-se também a profundidade efetiva do sistema radicular da cultura de citros igual a $50 \mathrm{~cm}$ e o fator de disponibilidade hídrica para a mesma cultura igual a 0,8 .

\subsubsection{Avaliações de vazão}

Efetuaram-se três avaliações de vazão em todos os gotejadores do experimento em 15/03/2003 (15,8 horas de irrigação), 13/06/2003 (37,81 horas) e 29/08/2003 (52,15 horas), e três amostragens nos dias 13/04/2003 (21,64 horas), $17 / 05 / 2003$ (27,32 horas) e 17/07/2003 (44,43 horas). O momento dessas avaliações também está apresentado na Figura 10, de acordo com o tempo acumulado de irrigação.

Nas avaliações completas coletou-se o volume de água durante cinco minutos, colocando-se quatro linhas gotejadoras sobre coletores de água, de forma seqüencial e defasadas em um minuto. Depois de se efetuar a leitura das quatro linhas, efetuava-se a leitura de outras quatro linhas, e assim sucessivamente, até a $48^{\mathrm{a}}$ linha de irrigação, com o auxílio de um grupo de 10 pessoas.

O tempo de teste perfazia 6 horas, incluindo leitura e anotação dos valores, manutenção, correção de problemas, mudança de ponto de controle de pressão e regulagem desta em cada tratamento. 
As amostragens consistiram da coleta de água de quatro gotejadores por parcela/tratamento, nas linhas centrais do experimento (seção delimitada por linhas pontilhadas na Figura 9). Os gotejadores avaliados estavam a 1/4, 2/4, $3 / 4$ e final do comprimento de cada uma das quatro linhas de irrigação centrais em cada manejo, totalizando 16 linhas de irrigação ao final da avaliação. O procedimento de coleta foi o mesmo adotado para a avaliação completa, porém com um número reduzido de emissores e pessoas.

\subsubsection{Seleção dos modelos de gotejadores versus tipos de manejo}

Depois das avaliações foram feitos os cálculos do coeficiente de variação de vazão médio e do grau de entupimento médio dos modelos testados, pelas equações (5) e (6). Também se desenvolveram gráficos de probabilidade simples com os dados de vazão de cada emissor, visando auxiliar na seleção, reduzindo a interferência de valores extremos que usualmente ocorrem dentre os valores médios (completa obstrução de emissores), e interpretando dados que não seguiram uma distribuição normal.

Os menores coeficientes de variação de vazão e os graus de entupimento, posteriores à análise estatística, aliados a análise probabilística, indicaram as melhores combinações de gotejadores e tipos de manejos. A condição oposta também foi considerada, ou seja, os maiores coeficientes de variação de vazão e graus de entupimento, posteriores à análise estatística, e a análise probabilística indicaram os piores tipos de manejos a cada modelo de gotejador.

\subsubsection{Qualidade da água residuária}

Nesta terceira etapa do trabalho também foi utilizada água residuária (efluente) oriunda dos tratamentos secundário (físicos e biológicos) do esgoto doméstico municipal da ETE da Bacia do Ribeirão Piracicamirim. 
Foram efetuadas coletas de água antes e após os filtros, a fim de caracterizá-la fisica, quimica e biologicamente. As amostras foram coletadas no período da manhã, utilizando recipientes apropriados e lavados com a mesma água. As amostras foram encaminhadas a laboratórios especializados em Piracicaba, dos quais obtiveram-se os valores apresentados nas Tabelas de 10 a 12. Alguns resultados são de amostras coletadas e analisadas pela ETE, por esse motivo há a caracterização apenas anterior ao sistema de filtragem.

Tabela 10 - Características referentes às coletas de água realizadas antes (AF) e depois (DF) da filtragem para condutividade elétrica (CE), $\mathrm{pH}$, nitrogênio total $(\mathrm{N})$, demanda bioquímica de oxigênio (DBO) e demanda química de oxigênio (DQO)

\begin{tabular}{|c|c|c|c|c|c|c|}
\hline \multirow{2}{*}{ Data } & \multirow{2}{*}{ Coleta } & \multirow{2}{*}{ 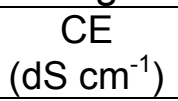 } & \multirow[t]{2}{*}{$\mathrm{pH}$} & \multirow{2}{*}{\multicolumn{2}{|c|}{$\begin{array}{c}\text { DBO } \\
\left(\mathrm{mg} \mathrm{L}^{-1}\right) \\
\end{array}$}} & $\mathrm{DQO}$ \\
\hline & & & & & & \\
\hline $25 / 03 / 03$ & $\mathrm{AF}$ & $0,0057 \mathrm{~B}$ & $7,2 \mathrm{M}$ & $24,0 \mathrm{BM}$ & $16,2 \mathrm{~B}$ & $57 \mathrm{~B}$ \\
\hline $16 / 04 / 03$ & $A F$ & $0,0058 \mathrm{~B}$ & $7,2 \mathrm{M}$ & -- & $11 \mathrm{~B}$ & $64 \mathrm{~B}$ \\
\hline $24 / 04 / 03$ & $\begin{array}{l}A F \\
D F\end{array}$ & $\begin{array}{l}0,0059 \mathrm{~B} \\
0,0059 \mathrm{~B}\end{array}$ & $\begin{array}{l}7,7 \mathrm{M} \\
7,6 \mathrm{M}\end{array}$ & $\begin{array}{l}24,0 \text { BM } \\
22,3 \mathrm{BM}\end{array}$ & $\begin{array}{l}24 \mathrm{~B} \\
15 \mathrm{~B}\end{array}$ & $\begin{array}{l}99 \mathrm{~B} \\
51 \mathrm{~B}\end{array}$ \\
\hline $23 / 05 / 03$ & $\begin{array}{l}\mathrm{AF} \\
\mathrm{DF}\end{array}$ & $\begin{array}{l}0,0059 \mathrm{~B} \\
0,0058 \mathrm{~B}\end{array}$ & $\begin{array}{l}7,8 \mathrm{M} \\
7,8 \mathrm{M}\end{array}$ & $\begin{array}{c}22,6 \mathrm{BM} \\
13,3 \mathrm{~B}\end{array}$ & $\begin{array}{l}25 \mathrm{~B} \\
19 \mathrm{~B}\end{array}$ & $\begin{array}{l}78 \mathrm{~B} \\
76 \mathrm{~B}\end{array}$ \\
\hline $\begin{array}{l}24 / 07 / 03 \\
27 / 08 / 03\end{array}$ & $\begin{array}{l}A F \\
A F\end{array}$ & $\begin{array}{l}0,0062 \mathrm{~B} \\
0,0061 \mathrm{~B}\end{array}$ & $\begin{array}{l}7,2 \mathrm{M} \\
7,1 \mathrm{M}\end{array}$ & $35, \overline{0}$ BM & $27 \mathrm{~B}$ & $\begin{array}{l}82 \mathrm{~B} \\
83 \mathrm{~B}\end{array}$ \\
\hline 29/08/03 & $\mathrm{AF}$ & $0,0061 \mathrm{~B}$ & $6.8 \mathrm{M}$ & -- & -- & -- \\
\hline
\end{tabular}

As letras seguidas dos números correspondem aos níveis baixo (B), baixo a médio (BM) e médio (M) para reúso de águas em irrigação. Não correspondem aos níveis restritivos de entupimento de gotejadores. Fontes utilizadas para comparação dos níveis: Ayers \& Westcot (1989), Pescod (1992) e, Crook $^{5}$ e USEPA ${ }^{6}$ citados por Mancuso \& Santos (2003).

${ }^{5}$ CROOK, J. Critérios de qualidade de água de reúso. Revista DAE, v.174, p 10-18, 1993.

${ }^{6}$ US ENVIRONMENTAL PROTECTION AGENCY. Guidelines for water reuse. EPA / 625/ R-92/004. Washington, 1992. 
Tabela 11. Características biológicas e físicas analisadas referentes às coletas de água realizadas antes (AF) e depois (DF) da filtragem

\begin{tabular}{|c|c|c|c|c|c|c|c|}
\hline \multirow[b]{2}{*}{ Data } & \multirow[b]{2}{*}{ Coleta } & \multicolumn{2}{|c|}{ Coliformes } & \multicolumn{3}{|c|}{ Sólidos } & Turbidez \\
\hline & & $\begin{array}{l}\text { Totais } \\
\text { (NMP } 1 \\
\end{array}$ & $\begin{array}{c}\text { Fecais } \\
\left.00 \mathrm{~mL}^{-1}\right)\end{array}$ & Totais & $\begin{array}{r}\text { Suspensos } \\
\left(\mathrm{mg} \mathrm{L}^{-1}\right)\end{array}$ & Dissolvidos & (UNT) \\
\hline $25 / 03 / 03$ & $\mathrm{AF}$ & -- & -- & $296 \mathrm{~B}$ & $14 \mathrm{~B}$ & $282 \mathrm{~B}$ & -- \\
\hline $16 / 04 / 03$ & $\mathrm{AF}$ & -- & -- & $312 \mathrm{~B}$ & $20 \mathrm{~B}$ & $292 \mathrm{~B}$ & -- \\
\hline 24/04/03 & $\begin{array}{l}\mathrm{AF} \\
\mathrm{DF}\end{array}$ & $\begin{array}{l}8,4 \cdot 10^{6} \mathrm{~A} \\
2,1 \cdot 10^{6} \mathrm{~A}\end{array}$ & $\begin{array}{l}2,2 \cdot 10^{6} \mathrm{~A} \\
9,6 \cdot 10^{5} \mathrm{~A}\end{array}$ & $\begin{array}{l}314 \mathrm{~B} \\
310 \mathrm{~B}\end{array}$ & $\begin{array}{l}19 \mathrm{~B} \\
12 \mathrm{~B}\end{array}$ & $\begin{array}{l}295 \mathrm{~B} \\
298 \mathrm{~B}\end{array}$ & $\begin{array}{l}1,5 \mathrm{~B} \\
2,3 \mathrm{~B}\end{array}$ \\
\hline 25/06/03 & $\mathrm{AF}$ & -- & -- & $322 \mathrm{~B}$ & $27 \mathrm{~B}$ & $295 \mathrm{~B}$ & -- \\
\hline $17 / 07 / 03$ & $\begin{array}{l}\text { AF } \\
\text { DF }\end{array}$ & $\begin{array}{l}2,4 \cdot 10^{7} \mathrm{~A} \\
9,1 \cdot 10^{5} \mathrm{~A}\end{array}$ & $\begin{array}{l}7,3 \cdot 10^{6} \mathrm{~A} \\
2,6 \cdot 10^{5} \mathrm{~A} \\
\end{array}$ & $\begin{array}{l}-- \\
--\end{array}$ & - & -- & -- \\
\hline
\end{tabular}

As letras seguidas dos números correspondem aos níveis baixo (B), baixo a médio (BM) e médio (M) para reúso de águas em irrigação. Não correspondem aos níveis restritivos de entupimento de gotejadores. Fontes utilizadas para comparação dos níveis: Ayers \& Westcot (1989), Pescod (1992) e, Crook (1993) e USEPA (1999) citados por Mancuso \& Santos (2003).

Tabela 12. Características químicas analisadas referentes às coletas de água realizadas antes (AF) e depois (DF) da filtragem

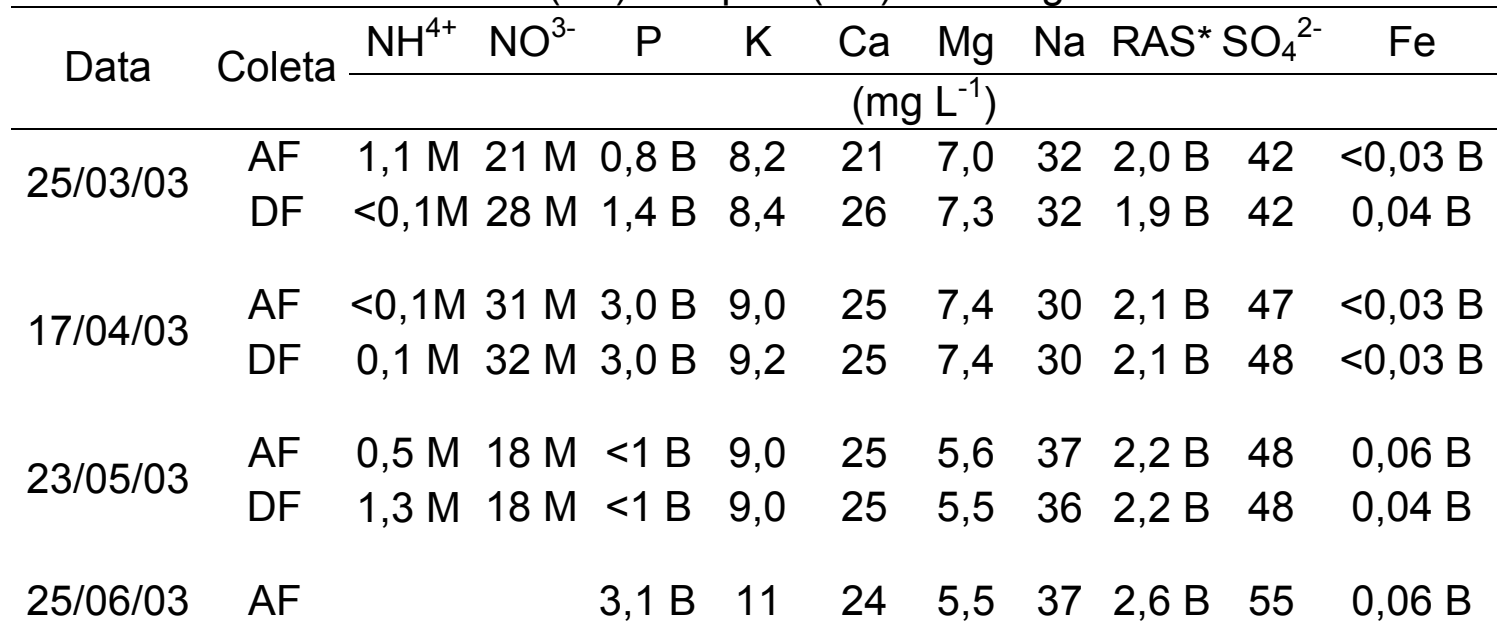


Tabela 12. Características químicas analisadas referentes às coletas de água realizadas antes (AF) e depois (DF) da filtragem

\begin{tabular}{|c|c|c|c|c|c|c|c|c|}
\hline \multirow{2}{*}{ Data } & \multirow{2}{*}{ Coleta } & $\mathrm{Cl}^{-}$ & B & $\mathrm{Zn}$ & $\mathrm{Cu}$ & $\mathrm{Mn}$ & $\mathrm{Al}$ & $\mathrm{Si}$ \\
\hline & & \multicolumn{7}{|c|}{$\left(\mathrm{mg} \mathrm{L}^{-1}\right)$} \\
\hline \multirow{2}{*}{ 25/03/03 } & AF & $81 \mathrm{~B}$ & $0,05 \mathrm{~B}$ & $<0,01$ & $B<0,02 B$ & \multirow{2}{*}{\multicolumn{2}{|c|}{$\begin{array}{l}0,05 B<0,1 B \\
0,04 B<0,1 B\end{array}$}} & 8,3 \\
\hline & DF & $60 \mathrm{~B}$ & $0,05 \mathrm{~B}$ & $0,02 \mathrm{E}$ & $B<0,02 B$ & & & 8,3 \\
\hline \multirow{2}{*}{$/ 04 / 03$} & $A F$ & $64 \mathrm{~B}$ & $0,05 \mathrm{~B}$ & $0,01 \mathrm{E}$ & $<0,02$ B & \multirow{2}{*}{\multicolumn{2}{|c|}{$\begin{array}{l}3<0,02 B<0,1 B \\
3<0,02 B<0,1 B\end{array}$}} & 8,7 \\
\hline & DF & $64 \mathrm{~B}$ & $0,05 \mathrm{~B}$ & $0,01 \mathrm{E}$ & $<0,02$ B & & & 8,8 \\
\hline \multirow{2}{*}{$23 / 05 / 03$} & $\mathrm{AF}$ & 7 B & $0,06 \mathrm{~B}$ & $<0,01$ & $B<0,03 B$ & \multirow{2}{*}{$\begin{array}{l}3<0,05 \\
3<0,05\end{array}$} & $B<C$ & 7,8 \\
\hline & $\mathrm{F}$ & $4 \mathrm{~B}$ & $0,06 \mathrm{~B}$ & $<0,01$ & $B<0,03 B$ & & $B<0,1 B$ & 7,7 \\
\hline $25 / 06 / 03$ & $A F$ & $69 \mathrm{~B} \quad \mathrm{O}$ & $0,06 \mathrm{~B}$ & $0,04 \mathrm{E}$ & $<0,01 \mathrm{~B}$ & $0,06 \mathrm{~B}$ & $B<0,1 B$ & 7,3 \\
\hline \multirow[t]{2}{*}{ Data } & \multirow[t]{2}{*}{ Coleta } & $\mathrm{Cd}$ & \multicolumn{2}{|c|}{$\mathrm{Cr}$} & $\mathrm{Ni}$ & $\mathrm{Sr}$ & $\mathrm{Pb}$ & $\mathrm{Ba}$ \\
\hline & & \multicolumn{7}{|c|}{$\left(\mathrm{mg} \mathrm{L}^{-1}\right)$} \\
\hline \multirow[t]{2}{*}{$25 / 03 / 03$} & $A F$ & $<0,004 \mathrm{~B}$ & \multicolumn{2}{|c|}{$B<0,003 B$} & $<0,02$ B & 0,13 & $<0,05 \mathrm{~B}$ & $0,03 \mathrm{~B}$ \\
\hline & DF & $<0,004 \mathrm{~B}$ & $B<0,0$ & $03 \mathrm{~B}$ & $<0,02 \mathrm{~B}$ & 0,15 & $<0,05 B$ & $0,02 \mathrm{~B}$ \\
\hline \multirow[t]{2}{*}{$17 / 04 / 03$} & $\mathrm{AF}$ & $<0,004 \mathrm{~B}$ & \multicolumn{2}{|c|}{$B<0,003 B$} & $<0,02 \mathrm{~B}$ & 0,14 & $<0,05 \mathrm{~B}$ & $0,02 \mathrm{~B}$ \\
\hline & DF & $<0,004 \mathrm{~B}$ & $B<0,0$ & 03 B & $<0,02 B$ & 0,14 & $<0,05 B$ & $0,02 \mathrm{~B}$ \\
\hline \multirow[t]{2}{*}{$23 / 05 / 03$} & $\mathrm{AF}$ & $<0,004 \mathrm{~B}$ & \multicolumn{2}{|c|}{$<0,004 \mathrm{~B}$} & $<0,02$ B & 0,15 & $<0,05 \mathrm{~B}$ & $0,03 \mathrm{~B}$ \\
\hline & DF & $<0,004 B$ & \multicolumn{2}{|c|}{$B<0,004 B$} & $<0,02 \mathrm{~B}$ & 0,14 & $<0,05 B$ & $0,02 \mathrm{~B}$ \\
\hline 25/06/03 & $\mathrm{AF}$ & $<0,01 \mathrm{~B}$ & \multicolumn{2}{|c|}{$<0,01 \mathrm{~B}$} & $<0,05 \mathrm{~B}$ & 0,13 & $<0,07$ B & $0,02 \mathrm{~B}$ \\
\hline
\end{tabular}

As letras seguidas dos números correspondem aos níveis baixo (B), baixo a médio (BM) e médio (M) para reúso de águas em irrigação. Não correspondem aos níveis restritivos de entupimento de gotejadores. Fontes utilizadas para comparação dos níveis: Ayers \& Westcot (1989), Pescod (1992) e, Crook (1993) e USEPA (1999) citados por Mancuso \& Santos (2003).

* Relação de adsorção de sódio calculada utilizando os valores de $\mathrm{Ca}, \mathrm{Mg}$ e $\mathrm{Na}$.

\subsubsection{Análise estatística}

Foi realizada a análise de variância (teste F) e testes de comparação de média por Tukey a $5 \%$ de significância, utilizando o programa computacional SAS, a cada análise completa de vazão, para o grau de entupimento e para o coeficiente de variação de vazão. Também se utilizou o teste de Tukey a $1 \%$ de probabilidade para análises de regressão, realizadas pelo mesmo programa 
computacional. O esquema da análise de variância utilizado está apresentado na Tabela 13.

Tabela 13. Esquema da análise de variância utilizada na terceira etapa do trabalho para o grau de entupimento e o coeficiente de variação

\begin{tabular}{cc}
\hline Causas de variação & Graus de liberdade \\
\hline Tipos de manejo $(\mathrm{M})$ & 3 \\
Modelos de gotejador $(\mathrm{G})$ & 3 \\
Interação M x G & 9 \\
Tratamentos & 15 \\
Resíduo & 32 \\
Total & 47 \\
\hline
\end{tabular}

\subsubsection{Análise probabilística da vazão dos gotejadores}

A partir dos dados de vazão obtidos das avaliações em campo, realizaram-se gráficos de probabilidade simples. Para os gráficos de probabilidade, a comparação foi realizada pela razão de vazão de cada gotejador quando usado em relação à vazão do gotejador quando novo (mesma vazão média do lote utilizada para cálculos de grau de entupimento) em comparação ao percentual de probabilidade de encontrar a razão desejada. Para esta análise utilizou-se o software KaleidaGraph.

Elaborou-se uma tabela com os percentuais de probabilidade de se encontrar as razões de vazão na faixa de $\pm 5 \%$ de variação, ou seja, - 1,05 a $+1,05$, para cada combinação de modelo de gotejador e tipo de manejo. Como exemplo, pode-se considerar o mesmo apresentado na metodologia de análises probabilísticas da segunda etapa deste trabalho. 


\section{RESULTADOS E DISCUSSÃO}

\subsection{Caracterização dos gotejadores novos}

Os resultados desta etapa, em relação ao ensaio inicial, estão apresentados na Tabela 14.

Em geral os modelos avaliados apresentaram coeficientes de variação de fabricação inferiores ou próximos a $10 \%$, assim como uniformidades de distribuição próximas ou superiores a $90 \%$. Tais características indicam que os emissores novos possuem boa qualidade.

Contudo, alguns apresentam coeficiente de variação de fabricação que são ligeiramente superiores aos fornecidos pelos fabricantes em catálogos (Tabela 5). Isso pode ocorrer, pois como comentado por Resende (2003), material de lotes fornecidos por fabricantes por doação em alguns casos podem conter algum tipo mínimo de problema técnico, embora não seja verdade que material doado seja sempre aquele com defeitos de fabricação.

De acordo com a classificação do coeficiente de variação de fabricação citada por Keller \& Bliesner (1990), a maioria dos emissores é excelente $\left(\mathrm{CV}_{\mathrm{f}}<5 \%\right)$ e somente quatro são marginais quanto a este coeficiente. A ausência de emissores em classificação pobre ou inaceitável permitiu a utilização dos mesmos lotes na segunda fase experimental.

Essa decisão também é reforçada pela publicação da ASAE (1988) a qual classifica como de boa aceitabilidade os emissores com 85 a $90 \%$ de uniformidade estatística. Conforme os dados apresentados na Tabela 14, a menor uniformidade estatística $(89,73 \%)$ ocorre no gotejador com maior 
coeficiente de variação de fabricação $(10,27 \%)$, que permanece, entretanto, dentro da faixa mencionada.

Também se pode enquadrar os emissores na classificação da uniformidade de emissão proposta na publicação da ASAE (1988), que se baseia nos 25 menores valores de vazão igualmente à metodologia empregada neste trabalho, que considera a equação (3). Verifica-se que a menor $U D_{\text {novo }}$ $(91,02 \%)$ é classificada como satisfatória.

Tabela 14. Valores médios de vazão $\left(q_{\text {novo }}\right)$, coeficiente de variação de fabricação $\left(\mathrm{CV}_{\mathrm{f}}\right)$ e uniformidade de distribuição (UD novo para pressão de ensaio de $98 \mathrm{kPa}$

\begin{tabular}{cccc}
\hline Modelo & $\begin{array}{c}\text { qnovo }_{(\text {no }} \\
\left(\mathrm{L} \mathrm{h}^{-1}\right)\end{array}$ & $\begin{array}{c}\mathrm{CV}_{\mathrm{f}} \\
(\%)\end{array}$ & $\begin{array}{c}\mathrm{UD}_{\text {novo }} \\
(\%)\end{array}$ \\
\hline $\mathrm{A}$ & 2,55 & 4,09 & 94.75 \\
$\mathrm{~B}$ & 1,61 & 1,68 & 97.93 \\
$\mathrm{C}$ & 2,06 & 3,97 & 95.97 \\
$\mathrm{D}$ & 2,61 & 10,27 & 91.03 \\
$\mathrm{E}$ & 1,61 & 4,90 & 94.05 \\
$\mathrm{~F}$ & 2,13 & 7,33 & 95.13 \\
$\mathrm{G}$ & 2,34 & 2,19 & 97.25 \\
$\mathrm{H}$ & 2,72 & 9,73 & 91.07 \\
$\mathrm{I}$ & 1,76 & 2,10 & 97.64 \\
$\mathrm{~J}$ & 1,85 & 2,09 & 97.64 \\
$\mathrm{~K}$ & 1,73 & 1,93 & 97.74 \\
$\mathrm{~L}$ & 1,70 & 7,93 & 91.02 \\
$\mathrm{M}$ & 0,89 & 2,40 & 97.26 \\
$\mathrm{~N}$ & 2,13 & 2,16 & 97.35 \\
$\mathrm{O}$ & 1,03 & 3,00 & 96.20 \\
\hline
\end{tabular}

O segundo ensaio laboratorial resultou nas curvas vazão versus pressão apresentadas na Figura 12. As equações dos gotejadores não autocompensantes, correspondentes a cada curva seguem o modelo apresentado na equação (11). 

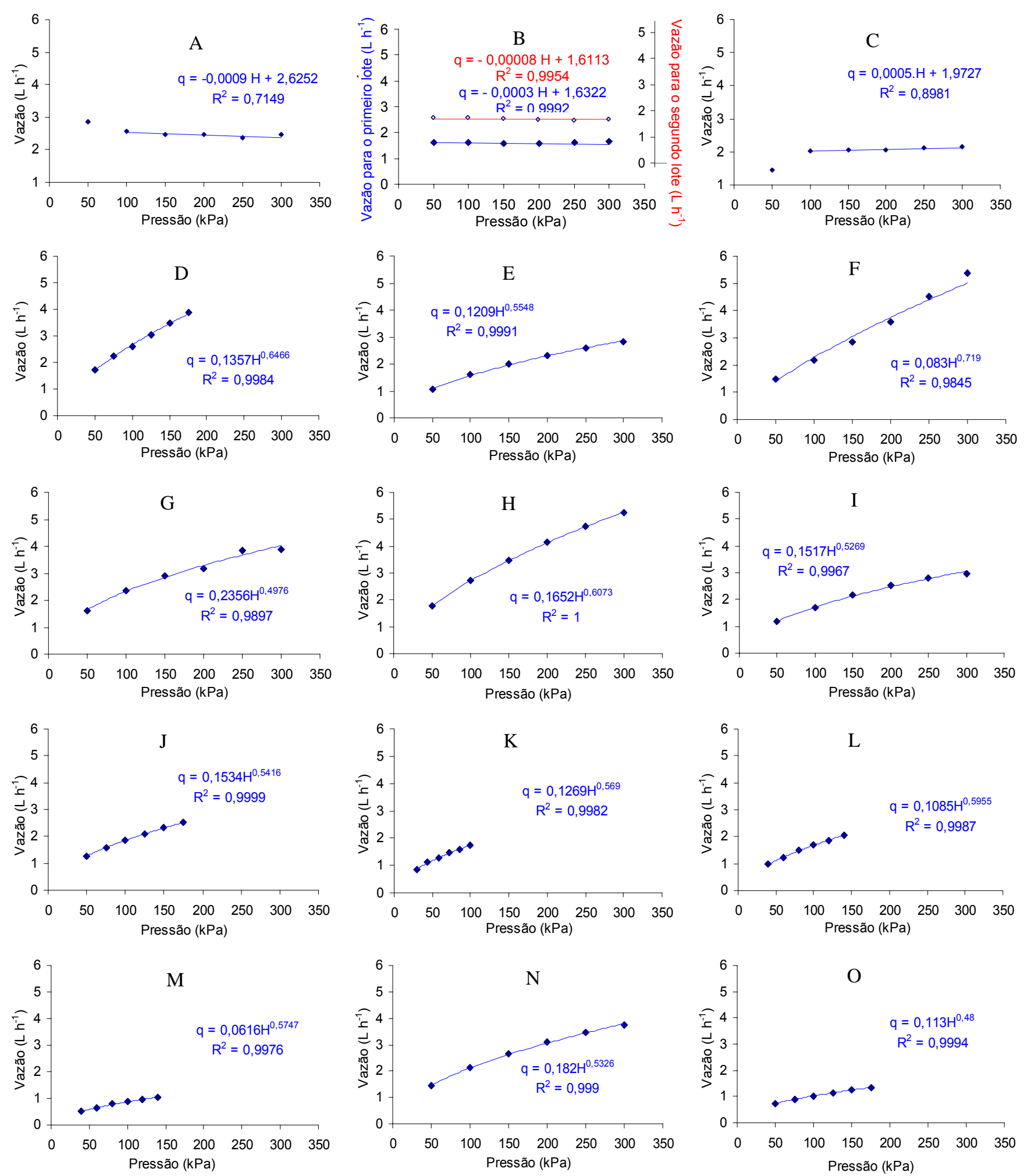

Figura 12 - Curvas vazão $(q)$ versus pressão $(H)$ dos gotejadores novos, obtidas em laboratório 
$\mathrm{q}=\mathrm{K} \mathrm{H}^{\mathrm{x}}$

em que,

$$
\begin{array}{ll}
q & \text { - vazão do gotejador, } \mathrm{L} \mathrm{h}^{-1} \text {; } \\
\mathrm{K} & \text { - coeficiente referente às características do emissor, adimensional; } \\
\mathrm{H} & \text { - pressão de funcionamento na entrada do emissor, } \mathrm{kPa} \text {; e } \\
\mathrm{X} & \text { - expoente de descarga, adimensional. }
\end{array}
$$

No caso dos gotejadores auto-compensantes, ajustou-se os dados por meio de uma regressão linear. Regressões lineares são mais indicadas para gotejadores auto-compensantes devido à propriedade dos mesmos de manterem a vazão aproximadamente constante para diferentes pressões de funcionamento, na faixa de operação recomendada pelo fabricante.

Nos gotejadores A e C, optou-se por uma exclusão dos pontos a $50 \mathrm{kPa}$ das respectivas equações, pois se considera que a essa pressão estes emissores não atingem a pressurização da membrana elástica presente nos mesmos, ocasionando valores acima e abaixo da faixa de funcionamento do sistema auto-compensante, respectivamente.

Em gotejadores não auto-compensantes ou de fluxo turbulento, as regressões exponenciais apresentaram bons ajustes, incluindo-se todos os pontos ensaiados. Segundo Keller \& Bliesner (1990) estes gotejadores são classificados como emissores de passagens tortuosas de água, pois os expoentes das equações dos mesmos se situam entre 0,5 e 0,7 , e também como turbulento, pois os expoentes de descarga aproximam-se de 0,5. A tortuosidade mencionada, pode favorecer ao entupimento, principalmente no caso da formação de depósitos em pontos de mudanças acentuadas da trajetória da água no emissor como citado por Pizarro (1996), ou em zonas mortas (regiões em que o número de Reynolds é inferior a 2000 e/ou regiões que permitem a deposição de sedimentos), como citado por Lopez et al. (1997).

$O$ regime turbulento nesses emissores reduz o risco das sedimentações e é uma das razões pelas quais os mesmos são utilizados atualmente, pois para um regime turbulento supõe-se uma certa ação auto-limpante. Isto não é perfeitamente verdadeiro quando se trata de crescimento bacteriano e formação 
de biofilme, que tem propriedade aderente aos materiais plásticos constituintes da tubulação e dos gotejadores. Para se evitar a aderência de biofilme, existem atualmente no mercado tubulações com revestimento interno plástico misturado a sulfato de cobre, porém com custo relativamente superior e indicadas para uso enterrado, como é o caso do modelo Geoflow produzido nos Estados Unidos. Existe também outros emissores para uso enterrado, além do Geoflow (que apresenta trifluralina nos emissores para evitar a intrusão radicular) e do Bioline (que possui um agente antibacteriano impregnado em seus emissores). Para maiores detalhes quanto a entupimentos causado por raízes, aconselhase o trabalho escrito por Resende (2003).

Os expoentes de descarga das equações dos gotejadores, caracterizados pelo regime hidráulico no interior do emissor, não atingem a 0,7, com exceção do modelo $\mathrm{F}$. Isto significa que a maioria dos emissores não é caracterizada como de longo comprimento de passagem de água, pois os expoentes não se encontram na faixa de 0,7 a 0,8 , descrita por Keller \& Bliesner (1990). O modelo $F$ é o que apresenta maior comprimento de passagem de água $(314 \mathrm{~mm})$ e também o maior expoente de descarga $(0,719)$. Além disso, nota-se que os fabricantes desempenharam esforços em fabricar emissores com menores comprimentos de passagem nos últimos anos, pois estes apresentavam valores de 520 e $960 \mathrm{~mm}$, como utilizado em trabalho desenvolvido por Adin \& Sacks (1991), com exceção do modelo autocompensante que possuia $25 \mathrm{~mm}$, ou seja, próximo ao encontrado atualmente para emissores com essa forma de funcionamento. 


\subsection{Estudo da susceptibilidade dos gotejadores ao entupimento}

\subsubsection{Qualidade da água relacionadas ao risco de entupimento}

Dentre os fatores analisados, apresentados nas Tabelas 7 e 8 , e encontrados em literatura como restritivos ao uso da água residuária em sistemas de irrigação localizada (Tabela 3 ), verificou-se que não havia nenhuma restrição quanto aos sólidos suspensos e dissolvidos, e quanto à população bacteriana; mas se teve leve a moderada restrição quanto ao pH.

A temperatura da água ao passar pelo conjunto moto-bomba, filtros e tubulação (incluindo derivação e laterais de polietileno), incrementou cerca de $4{ }^{\circ} \mathrm{C}$ (medido após o último gotejador), melhorando a condição para desenvolvimento bacteriano e, assim, aumentando o potencial da água em entupir os emissores, pois ficou na faixa de 25 a $35{ }^{\circ} \mathrm{C}$ que é ideal para desenvolvimento de bactérias segundo von Sperling (1996).

Os valores de DBO e DQO indicaram a presença de material orgânico, usualmente na fração dissolvida, o qual pode ser utilizado por microrganismos, e para a formação de biofilme no interior do sistema de irrigação. Hamoda \& AlAwadi (1996) indicam valores de DQO entre 30 e $120 \mathrm{mg} \mathrm{L}^{-1}$ para irrigação sem relacionar o problema citado; Ali (1987) considerou DBO de $10 \mathrm{mg} \mathrm{L}^{-1}$ para irrigação irrestrita. Hills et al. (2000) utilizaram água com DBO de $16,4 \mathrm{mg} \mathrm{L}^{-1} \mathrm{e}$ Hassen et al. (2000) utilizaram DBO igual a $24 \mathrm{mg} \mathrm{L}^{-1}$ e DQO igual a $96 \mathrm{mg} \mathrm{L}^{-1}$. Isto indica que os valores encontrados de DBO e DQO estão próximos aos sugeridos em literatura; pórem, é importante observar que é necessário algum tipo de tratamento, ao menos filtragem, para retenção de material orgânico. Tratamento este, efetuado neste trabalho.

O valor de alcalinidade encontrado corresponde provavelmente, em sua maioria, à presença de bicarbonato $\left(\mathrm{HCO}_{3}{ }^{-}\right)$, pois o $\mathrm{pH}$ foi igual a 7,0 . De acordo com Ayers \& Westcot (1999), concentrações de bicarbonato acima de 5 meq $\mathrm{L}^{-1}$, ou seja, $305 \mathrm{mg} \mathrm{L}^{-1}$, provocam problemas graves quanto a 
precipitados no sistema de irrigação. Fato este, que possivelmente não ocorreu, pois a água utilizada possuía um valor aceitável quanto à concentração de bicarbonato.

Os valores de nitrogênio e fosfato encontrados reafirmam a condição dessa água como suplemento nutricional às plantas, e interferem indiretamente no entupimento dos gotejadores, pois esses nutrientes também são úteis ao crescimento de bactérias.

\subsubsection{Avaliações de vazão e do entupimento}

Os gotejadores apresentaram diferentes sensibilidades, tanto em relação ao coeficiente de variação de vazão quanto ao grau de entupimento. Também percebidas nos resultados oriundos das análises de probabilidade das vazões dos gotejadores.

\subsubsection{Coeficiente de variação de vazão}

Considerando-se a avaliação de vazão dos 50 gotejadores para cada modelo, obteve-se como resultado os valores de coeficiente de variação de vazão $\left(\mathrm{CV}_{\mathrm{q}}\right)$ apresentados na Tabela 15.

Comparando os valores da Tabela 15 aos coeficientes de variação de fabricação, também apresentados na Tabela 14, nota-se um incremento generalizado após 373 horas de aplicação da água residuária. Isso indica que o entupimento ocorre de maneira desuniforme, independentemente da uniformidade em que o gotejador é fabricado.

Em comparação, a uniformidade de distribuição sofreu grande mudança, atingindo valores muito inferiores ao indicado como inaceitável na publicação da ASAE (1988). Apenas os modelos $\mathrm{G}$ e $\mathrm{N}$ encontravam-se em níveis aceitáveis depois das 373 horas. Ainda, no caso de considerar $90 \%$ como uniformidade 
de distribuição mínima, tal como recomendada por Karmeli \& Keller ${ }^{7}$ citados por Nakayama \& Bucks (1981), poucos são os modelos que atendem a esse critério.

Tabela 15. Coeficientes de variação de vazão antes $\left(C_{f}\right)$ e após $\left(C V_{q}\right)$ a aplicação de 373 horas de água residuária, e a uniformidade de distribuição antes $\left(U D_{\text {novo }}\right)$ e após $\left(U D_{373} \mathrm{~h}\right)$ esse período para os modelos de gotejadores testados

\begin{tabular}{ccccc}
\hline Modelo & $\mathrm{CV}_{\mathrm{f}}(\%)$ & $\mathrm{CV}_{\mathrm{q}}(\%)$ & $\mathrm{UD}_{\text {novo }}(\%)$ & $\mathrm{UD}_{373 \mathrm{~h}}(\%)$ \\
\hline $\mathrm{A}$ & 4,09 & 10,27 & 94.75 & 87.57 \\
$\mathrm{~B}$ & 1,68 & 7,00 & 97.93 & 92.79 \\
$\mathrm{C}$ & 3,97 & 8,32 & 95.97 & 89.33 \\
$\mathrm{D}$ & 10,27 & 9,81 & 91.03 & 90.45 \\
$\mathrm{E}$ & 4,90 & 28,03 & 94.05 & 57.81 \\
$\mathrm{~F}$ & 7,33 & 20,60 & 95.13 & 71.49 \\
$\mathrm{G}$ & 2,19 & 5,19 & 97.25 & 93.25 \\
$\mathrm{H}$ & 9,73 & 14,52 & 91.07 & 83.19 \\
$\mathrm{I}$ & 2,10 & 6,79 & 97.64 & 91.57 \\
$\mathrm{~J}$ & 2,09 & 10,79 & 97.64 & 89.57 \\
$\mathrm{~K}$ & 1,93 & 21,50 & 97.74 & 70.27 \\
$\mathrm{~L}$ & 7,93 & 10,94 & 91.02 & 86.10 \\
$\mathrm{M}$ & 2,40 & 22,55 & 97.26 & 69.94 \\
$\mathrm{~N}$ & 2,16 & 6,35 & 97.35 & 92.48 \\
$\mathrm{O}$ & 3,00 & 8,43 & 96.20 & 91.41 \\
\hline
\end{tabular}

Ocorreram variações de vazão inferiores a $10 \%$ nos modelos $B, C, D, G$, $\mathrm{I}, \mathrm{N}$ e $\mathrm{O}$, sendo estes os melhores de acordo com o critério de variação de vazão. Os demais foram classificados na faixa de piores para o critério analisado, principalmente os emissores $\mathrm{E}, \mathrm{F}, \mathrm{K}$ e $\mathrm{M}$, que atingiram valores acima de $20 \%$, coincidindo com os menores valores de uniformidade de distribuição, calculados pela equação (3). Esta coincidência é justificada pela elevada correlação entre os coeficientes de variação e os coeficientes de uniformidade, apresentada por Resende (1999).

\footnotetext{
${ }^{7}$ KARMELI, D.; KELLER, J. Trickle irrigation design. Glendora : Rain Bird Manufacturing Corporation, 1975. 132 p.
} 
Notou-se que os modelos $\mathrm{K}, \mathrm{M}$ e E, embora fossem classificados como excelentes quanto ao $\mathrm{CV}_{\mathrm{f}}$, tiveram os maiores acréscimos de variação de vazão após a aplicação da água residuária. Essa variação também é observada nos dados de grau de entupimento apresentados nos Anexos A e B. Assim, diferentemente do mencionado por Nakayama et al. (1979), a fabricação de emissores com baixos coeficientes de variação de vazão não garante baixo incremento na variação depois da instalação e operação do sistema. A explicação para este fato, consiste provavelmente nas características geométricas e funcionais intrínsecas do emissor testado, aliadas ao regime laminar favorável ao desenvolvimento bacteriano, e à presença de sólidos suspensos e dissolvidos que passam pelo sistema de filtragem e que tendem a se acumular ao final das linhas (observado na água coletada durante as avaliações de vazão e em abertura para checagem).

Os modelos $\mathrm{K}$ e $\mathrm{M}$ não são auto-compensantes ou auto-limpantes, possuem labirinto retilíneo com zonas mortas, pequena profundidade $(0,4 \mathrm{~mm})$, comprimento de passagem de água superior a $175 \mathrm{~mm}$ e saída estreita $(0,4 \mathrm{~mm})$.

O modelo $M$ apresenta a menor vazão $\left(0,89 \mathrm{~L} \mathrm{~h}^{-1}\right.$ por emissor), ocasionando menor velocidade da água na tubulação gotejadora e favorecendo precipitações na mesma. Contudo, a entrada de água deste modelo se situa na porção superior da tubulação, reduzindo este efeito. Assim, a pequena velocidade na linha $\left(0,03 \mathrm{~m} \mathrm{~s}^{-1}\right)$ também tem interferência na formação do biofilme.

O modelo $\mathrm{E}$ apresenta tubulação com diâmetro inferior aos demais (12 $\mathrm{mm})$, ou seja, há maior superfície específica interna $\left(333 \mathrm{~m}^{2} \mathrm{~m}^{-3}\right)$, favorecendo a maior formação de biofilme por esta hipótese, havendo uma tendência deste se situar ao final da linha, ocasionando elevados graus de entupimento nesta parte, como observados no Anexo B. Entretanto, essa hipótese não pode ser entendida como uma explicação isolada ou conclusiva, pois se observa que os modelos $B, D$ e $G$, que tiveram bons coeficientes de 
variação de vazão, apresentam diâmetros de tubulação pouco superiores $(13,8$ a $14,2 \mathrm{~mm}$ ) e conseqüentemente superfícies específicas de $290 \mathrm{~m}^{2} \mathrm{~m}^{-3}$ e $282 \mathrm{~m}^{2} \mathrm{~m}^{-3}$. Além disso, analisando-se a superfície específica relativa a metro linear, e não por metro cúbico, poderia-se formular uma hipótese oposta, pois quanto maior o diâmetro interno da tubulação, maior é a superfície para crescimento bacteriano por metro linear. Novas pesquisas poderiam ser realizadas verificando as hipóteses de superfície específica mencionadas, pois não há estudos relacionando esta ao entupimento de emissores. Um fator também influente no modelo $E$ é a baixa velocidade da água em regime laminar ao final das linhas, aliado ao longo percurso de passagem de água $(170 \mathrm{~mm})$ no gotejador.

No modelo $F$, elevados entupimentos ao final das linhas em todo o trajeto no interior dos emissores, e não apenas em posições restritivas à passagem da água, são provavelmente efeitos do longo comprimento de passagem (314 mm) aliado à presença de sólidos e bactérias formadoras de biofilme. A variação de vazão também poderia ser considerada em relação a característica deste modelo, diferente dos demais, de apresentar emissores não soldados a tubulação e de estar situado entre segmentos de tubulação. Isto, no sentido de facilitar o desprendimento de biofilme no labirinto do gotejador para o meio exterior ou para locais restritivos à vazão no próprio emissor. Hipótese que não pôde ser comprovada pela metodologia utilizada. Para futuros estudos, sugerese testar métodos que não necessitem o corte da tubulação para visualização do entupimento, evitando-se a interferência na posição e estrutura do fator obstrutor no labirinto do gotejador independente do modelo e causa obstrutora.

\subsubsection{Grau de entupimento}

Na Figura 13 observam-se valores médios de reduções de vazão e de aumentos de vazão, tanto nas amostragens como na avaliação de todos os emissores na área. Os valores de grau de entupimento individual para cada emissor para todas as avaliações estão apresentados nos Anexos A e B. 


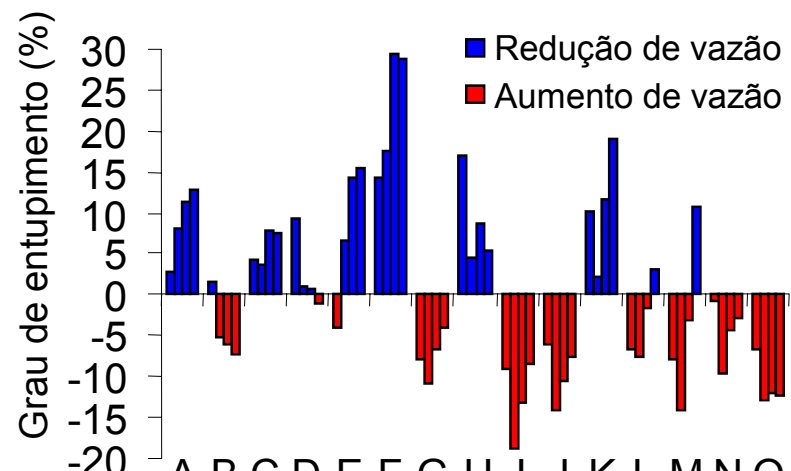

-20 A B CDEF G H I J K MNO

Modelos de gotejador

(a)

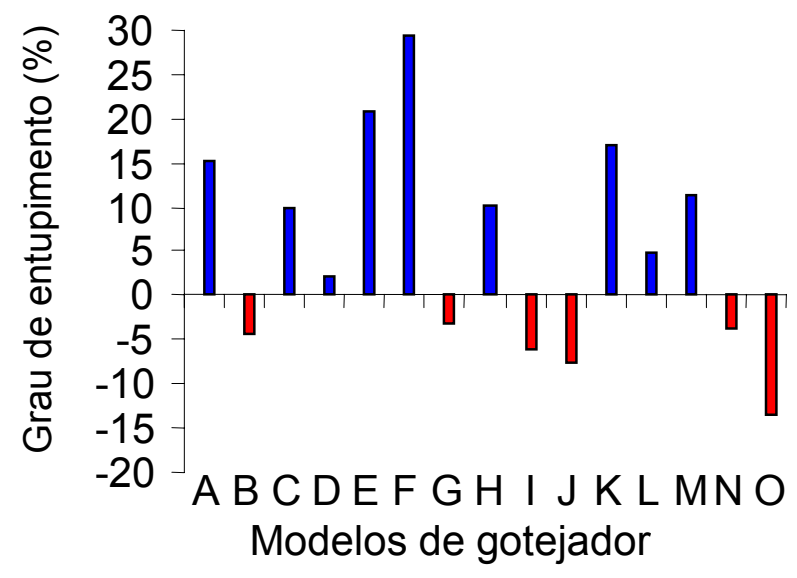

(b)

Figura 13 - Valores médios de grau de entupimento dos modelos de gotejador ao longo das avaliações de vazão a partir de uma amostra de 6 emissores feitas às 97, 198 e 300 e $373 \mathrm{~h}$ (a), e a partir de 50 emissores às 373 horas de aplicação de água residuária (b)

Quanto à amostragem verifica-se o entupimento gradual dos modelos $\mathrm{A}$, C, E, F e K. Estes apresentam forma em que o labirinto está disposto em emissor cilíndrico. Esta característica pode ser um fator auxiliar na obstrução, pois a entrada da água, no emissor, fica situada certas vezes na porção inferior da tubulação, sendo sujeita a obstrução física por precipitados e crescimento bacteriano. Entupimento em emissores cilíndricos são constatados em trabalhos de Gilbert et al. (1980) e Adin \& Sacks (1991). As pequenas seções de entrada $(0,3 \mathrm{~mm})$, comprimentos de passagem da água superior a $126 \mathrm{~mm}$ e 
as diversas mudanças na direção da água nos emissores com maior possibilidade de se encontrar zonas mortas são fatores agravantes. Sendo que estes normalmente são regiões curvas ou cantos presentes no emissor, nas quais se constata o depósito gradual de sedimentos, como constatado por Adin \& Sacks (1991), utilizando técnicas de microscopia e de raios X. Estes autores também descrevem tamanhos e formas de agregados que encontraram em emissores por eles estudados. Neste trabalho, verificou-se biofilmes nas zonas mortas, bem como nas paredes ao longo do labirinto dos emissores, incluindo os modelos cilíndricos.

Dentre duas das três avaliações amostrais e também para os gotejadores correspondentes às amostragens, na avaliação às 373 horas, 0 modelo $D$ foi o que apresentou valores médios mais próximos à vazão original obtida em laboratório, caracterizando-se assim como bom emissor no uso da água aplicada, quanto ao grau de entupimento.

Apesar do comprimento de passagem de água do modelo $D$ ser de aproximadamente $200 \mathrm{~mm}$, apenas $120 \mathrm{~mm}$ deste é composto por labirintos nos quais podem ocorrer crescimentos bacterianos. Esse comprimento de passagem é inferior ao dos modelos E (144 mm em labirinto) e F (280 mm em labirinto) e pode ser uma das explicações para a vazão nas amostragens estarem semelhantes ao de gotejadores novos. Outro fator auxiliar é a presença de dois orifícios de saída da água do emissor, característica esta, não presente no modelo E, cuja forma e funcionamento são similares, possuindo entretanto, entupimento acentuado.

Os modelos A e C apresentam mudanças repentinas na direções do fluxo da água, as quais, como citado anteriormente, favorecem o entupimento. Essas mudanças no fluxo são realizadas para possibilitar a passagem da água pela membrana elástica responsável pela compensação de pressão. A não ação de mecanismos auto-limpantes, como por exemplo o existente no modelo $\mathrm{B}$, provavelmente favoreceram ao entupimento encontrado nos modelos $\mathrm{A}$ e $\mathrm{C}$. 
Quanto à avaliação completa (373 horas de funcionamento), observou-se a seguinte ordem decrescente de valores médios de graus de entupimento para os modelos estudados: F, E, K, A, M, H, C, L e D, sendo constatados entupimentos tanto em gotejadores auto-compensantes como em não autocompensantes. Tais entupimentos ultrapassaram a $10 \%$ para os modelos $F, E$, $\mathrm{K}, \mathrm{A}$ e M, caracterizando estes como os piores em relação a este critério.

Os modelos F, E e K apresentam comprimentos de passagem maiores que os demais. O modelo $A$ apresenta menos e menores aberturas de entrada, e maior comprimento de passagem que o modelo $C$. Além disso, o modelo $A$ não possui contato da membrana com a entrada do emissor como acontece com o modelo $\mathrm{C}$. O modelo $\mathrm{M}$ apresenta forma semelhante ao modelo $\mathrm{K}$, e características favoráveis ao entupimento já mencionadas quando se discutiu o efeito nos coeficientes de variação de vazão desta etapa.

$O$ modelo $D$ foi também considerado como o melhor emissor para a avaliação completa, pois apresentou os menores valores médios de grau de entupimento. Isso provavelmente ocorre pelos mesmos motivos anteriormente discutidos para as avaliações amostrais.

Dentre os auto-compensantes, o modelo B foi o que se obteve o menor grau de entupimento, possivelmente devido à ação mais eficiente na expulsão de partículas por dispositivos próprios, ou seja, pela membrana elástica retangular situada sobre o labirinto. Porém, há também a possibilidade da membrana perder sua função permitindo aumentos de vazão por fadiga do material elástico citado por Keller \& Bliesner (1990) ou por ação de mucilagem no interior do emissor, mantendo a mesma flexionada. Contudo, o modelo B apresentou valor médio de vazões próximo à vazão quando novo, assim como outros emissores não-autocompensantes, tais como os modelos $D, L, G$ e N. 


\subsubsection{Análise probabilística da vazão dos gotejadores}

Quanto à análise probabilística, os resultados apresentados na Tabela 16 indicam como piores emissores os modelos A, F, J, O, C, I, M e E, e como melhores emissores os modelos B, G e D. A Tabela 16 foi realizada a partir do Anexo C.

Tabela 16. Probabilidade de encontrar emissores com vazão na faixa de variação de $\pm 5 \%$ em relação à vazão quando novo após 373 horas de aplicação de água residuária

\begin{tabular}{lccccccccccccccc} 
Modelo de gotejador & A & B & C & D & E & F & G & H & I & J & K & L & M & N & O \\
\hline Probabilidade (\%) & 1 & 61 & 19 & 45 & 27 & 1 & 55 & 34 & 25 & 9 & 37 & 31 & 25 & 42 & 4 \\
\hline
\end{tabular}

Os modelos B, D, M e E apresentaram-se facilmente disponíveis comercialmente e em estoque. Por este motivo, não se escolheu os emissores A, F, C e G para a terceira etapa do trabalho.

Outra característica de decisão foi que os modelos $\mathrm{B}, \mathrm{D}, \mathrm{M}$ e $\mathrm{E}$ apresentaram maior probabilidade de encontrar gotejadores abaixo da faixa de $\pm 5 \%$ (redução de vazão) em relação a acima. Isto significa que não considerou-se os emissores com aumentos de vazão (com maior probabilidade acima da faixa em relação a abaixo), como ocorreram para os modelos $\mathrm{J}$, O e I.

\subsubsection{Avaliação visual do entupimento}

O entupimento ocorreu internamente nos emissores como mostrado na Figura 14. Observou-se a presença de material obstrutivo uniformemente distribuído no labirinto do emissor e se concentrando nas paredes e zonas mortas do mesmo, embora tenha também sido visualizada mucilagem no interior da tubulação e na entrada de alguns emissores. A formação dessa mucilagem deveu-se, em parte, a não realização de abertura de finais de linhas para limpeza das mesmas, tendo a ausência dessa prática o propósito de 
potencializar os efeitos do entupimento e, conseqüentemente, facilitar a escolha dos modelos. Assim, como mencionado, a mucilagem contendo sólidos, provavelmente material orgânico, ferro e enxofre oxidado e presença das bactérias na água residuária são a causa mais provável do entupimento observado. Isso é confirmado por análises laboratoriais que detectaram a presença de ferro-bactérias e sulfo-bactérias nos gotejadores entupidos e ausência de algas no interior dos mesmos.
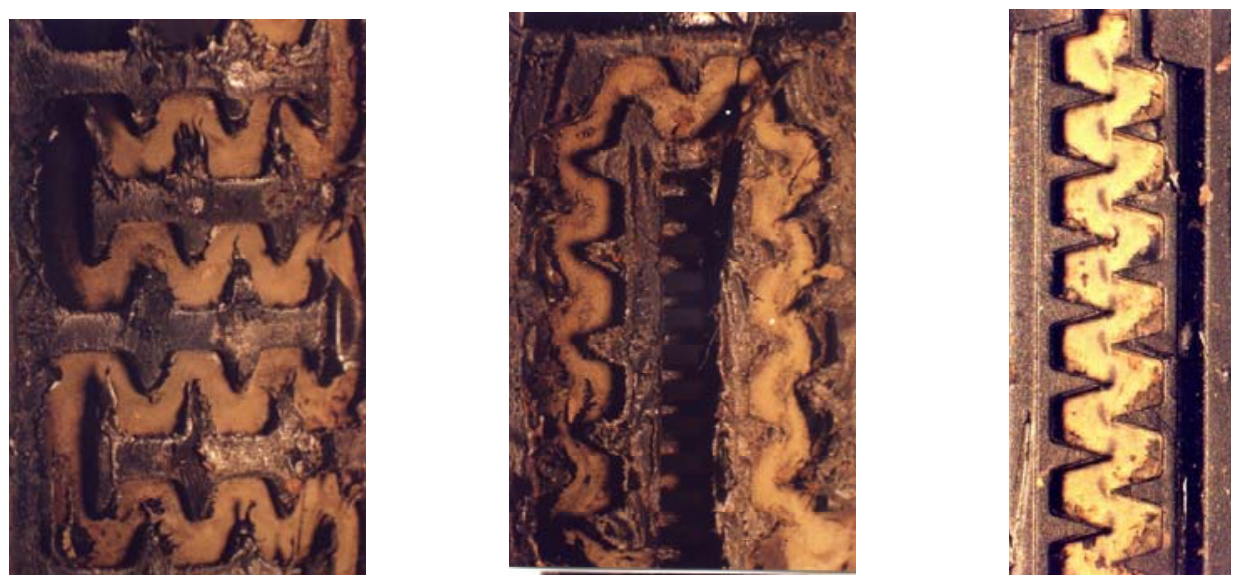

Figura 14 - Imagens de gotejadores abertos mostrando o entupimento

\subsubsection{Avaliações de vazão e aumentos de vazão}

Aumentos de vazão ocorreram nos mesmos emissores, tanto na avaliação completa como nas amostragens (Figura 13 e Anexos A e B). Leite (1995) e Costa (2000) encontraram oscilações na vazão relativa (que também correspondem a oscilações no grau de entupimento), incluindo o fato do aumento de vazão de gotejadores. Estes autores atribuíram esse fato ao desobstruções aleatórias que ocorriam pelo efeito de alguma eventual sobrepressão no sistema e de uma influência acentuada de temperatura na vazão. A hipótese de desobstruções aleatórias com efeito de eventuais sobrepressões sugeridas por Leite (1995) e Costa (2000), possivelmente se aplique aos modelos que apresentaram poucos gotejadores com aumento de 
vazão, como é o caso dos modelos $\mathrm{E}, \mathrm{H}, \mathrm{K}$, L e M (Anexo B). Além disso, o possível efeito da sobrepressão foi a cada linha, pois não se permitiu oscilações de pressão no início das laterais.

Quanto a temperatura, a água provavelmente aqueceu no interior da tubulação em momentos em que o sistema não estava em operação, conduzindo a uma dilatação permanente no material que compõe os emissores, como é o caso dos modelos I, J, $\mathrm{N}$ e O, os quais possivelmente tiveram a maior interferência e foram os que tiveram aumento de vazão em todos os emissores de ambas linhas. Essa hipótese também é sugerida por Airoldi (2003), o qual encontrou aumentos de vazão em emissores do modelo $O$ que ficaram expostos ao sol.

No caso da temperatura de água circulante, de acordo com Lopez et al. (1997) tem pouco efeito em gotejadores tipo labirinto. Em cálculos, utilizando-se os dados apresentados por este autor, observa-se um aumento de apenas $0,0079 \mathrm{~L} \mathrm{~h}^{-1}$ a cada aumento em $1{ }^{\circ} \mathrm{C}$, em emissor labiríntico de $4 \mathrm{~L} \mathrm{~h}^{-1}$ a $100 \mathrm{kPa}$, ou seja, um emissor com pressão e características construtivas similares a dos emissores utilizados e que apresentaram aumentos de vazão (B, G, I, J, L, M, N e O). Parchomchuk (1976) comenta que para temperaturas de água entre 5 e $40^{\circ} \mathrm{C}$ há variação teórica da vazão do emissor relativa a vazão a $20{ }^{\circ} \mathrm{C}$ de aproximadamente $2,8 \%$ a cada $1{ }^{\circ} \mathrm{C}$. Mas, o efeito da temperatura, de acordo com este autor, é minimizado pelo uso de emissores de regime turbulento.

Além das sobrepressões e da temperatura da água, características inerentes aos emissores também podem ter contribuido para os aumentos de vazão observados.

Um fator comum nos emissores, com exceção do modelo $G$, é que a maioria dos modelos com aumentos de vazão eram do tipo plano com comprimento de passagem relativamente curto $(<200 \mathrm{~mm})$. Porém, não há estudos que comprovem a influência da geometria do emissor no efeito mencionado. 
Outro motivo para os aumentos de vazão acima de $5 \%$, que ocorrem de maneira generalizada nos modelos I, J e O, possivelmente foi uma modificação intrínseca a estes emissores, como a presença inicial de componentes hidrofóbicos e posterior retirada dos mesmos pelo uso da água residuária. Esse efeito é observado na Figura 15, a qual indica, ao longo do tempo, como o grau de entupimento se comporta na comparação das vazões da $4^{\mathrm{a}}, 3^{\mathrm{a}}$ e $2^{\mathrm{a}}$ avaliações relativas às vazões da $1^{\mathrm{a}}$ avaliação (Figura 15a); da $4^{\mathrm{a}}$ e $3^{\mathrm{a}}$ relativas a $2^{a}$ (Figura 15b) e $4^{a}$ relativa a $3^{a}$ (Figura 15c). Dessa forma, constatou-se que ocorre menos aumentos de vazão a medida que se analisam os gráficos da Figura 15a a Figura15c. Nota-se também, que não houve aumentos de vazão na Figura 15c. Essa análise indica estabilidade ao final e conseqüentemente possível saída de alguma substância presente nos gotejadores quando novos até aproximadamente 300 horas de operação. Em adição, essa análise também continua indicando um elevado grau de entupimento para os modelos $\mathrm{E}$ e $\mathrm{M}$ (Figura 15c), reforçando a escolha destes para a fase experimental seguinte. 

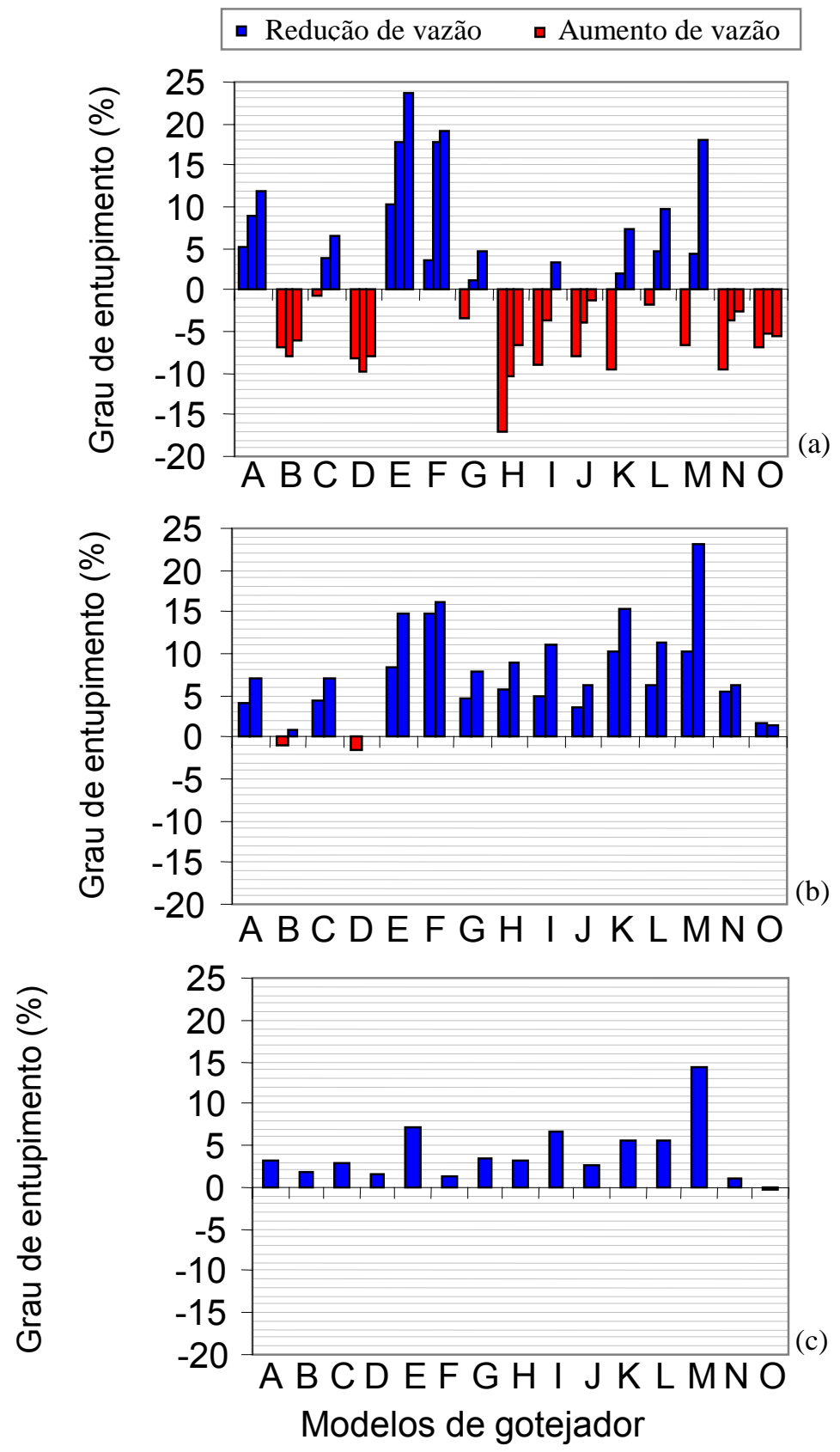

Figura 15 - Graus de entupimento relacionados às vazões relativas da $2^{\mathrm{a} / 1^{\mathrm{a}}}$, $3^{a} / 1^{a}$ e $4^{a} / 1^{a}$ avaliações (a), $4^{a} / 2^{a}$ e $3^{a} / 2^{a}$ avaliações (b) e $4^{a} / 3^{a}$ avaliações (c), ao invés de $1^{a}, 2^{a}, 3^{a}$ e $4^{a}$ avaliações/avaliação de gotejadores novos 


\subsubsection{Modelos de gotejadores selecionados}

Considerando a facilidade para a aquisição da tubulação gotejadora (para montagem da terceira etapa) e a possibilidade de incluir um modelo autocompensante e auto-limpante (B), um tipo plano e moldado $(\mathrm{M})$ e dois cilíndricos com desempenho diferenciado ( $E$ e $D$ ), não se incluíram os

gotejadores $\mathrm{F}, \mathrm{K}, \mathrm{G}$ e $\mathrm{A}$, mesmo tendo apresentado elevado grau de entupimento ( $A, F$ e K ), elevado coeficiente variação de vazão $(F$ e $K)$, pequeno valor desse coeficiente e baixa probabilidade de encontrar vazões fora da faixa de $\pm 5 \%(G)$, e baixa probabilidade de encontrar emissores nessa faixa ( $A, C$ e F). O fato da probabilidade de encontrar muitos emissores com vazão acima de $5 \%$ em relação ao gotejador quando novo, descartaram a escolha dos modelos I, J e O.

Portanto, em relação ao estudo de susceptibilidade dos emissores ao uso contínuo de água residuária, selecionaram-se como melhores os modelos: B (pequeno grau de entupimento, pequeno coeficiente de variação de vazão, fácil disponibilidade comercial, sistema auto-limpante e auto-compensante de pressão, e maior probabilidade de encontrar valores de vazão na faixa de $\pm 5 \%$ ) e $D$ (pequeno grau de entupimento, pequeno coeficiente de variação de vazão, disponibilidade em estoque e grande probabilidade de encontrar valores de vazão na faixa de $\pm 5 \%$ em relação à vazão de gotejadores quando novos). Como piores os modelos: E e M (elevado grau de entupimento, elevado coeficiente de variação de vazão, disponibilidade em estoque e grande probabilidade de se encontrar valores de vazão fora da faixa de $\pm 5 \%$ ).

Portanto, considerando o coeficiente de variação de vazão, o grau de entupimento e a análise de probabilidades, escolheu-se os modelos B e D como melhores e $\mathrm{E}$ e $\mathrm{M}$ como piores, para serem utilizados na fase de tipos de manejo versus modelos de gotejadores. 


\subsection{Estudo dos manejos preventivos ao entupimento}

\subsubsection{Qualidade da água, entupimento e filtragem}

Dentre as características da água apresentadas nas Tabelas de 10 a 12, nota-se como condições favoráveis ao entupimento: $\mathrm{pH}>7, \mathrm{H}_{2} \mathrm{~S}>2 \mathrm{mg} \mathrm{L}^{-1}$ (estimado pelo valor de enxofre encontrado) e coliformes totais em nível elevado, provavelmente equivalendo a valores superiores a $50000 \mathrm{UFC} \mathrm{ml}^{-1}$.

Segundo os critérios apresentados na Tabela 3 e os dados das Tabelas de 10 a 12, observa-se que a água é tolerável quanto ao potencial de risco de entupimento de sistemas de irrigação localizada, pois continha baixo conteúdo de sólidos em suspensão ( $S S<50 \mathrm{mg} \mathrm{L}^{-1}$ ), de sólidos dissolvidos $\left(\mathrm{SD}<500 \mathrm{mg} \mathrm{L}^{-1}\right)$, de ferro $\left(\mathrm{Fe}<0,1 \mathrm{mg} \mathrm{L}^{-1}\right)$, e de manganês $\left(\mathrm{Mn}<0,1 \mathrm{mg} \mathrm{L}^{-1}\right)$.

A água residuária utilizada também se mostrou adequada ao uso destinado, com baixo impacto poluidor ou fitotóxico quanto a metais pesados, cloreto e boro, comparando os valores obtidos aos encontrados em Pescod (1992) e Ayers \& Westcot (1999). Também, foi observado pela relação de adsorção de sódio (RAS) que houve baixo impacto na infiltração do solo. Além disso, os teores de nitrogênio, fósforo e potássio encontrados sugerem que estes nutrientes poderiam ser usados como fonte nutricional às plantas de tangerina. Contudo, como a pesquisa foi conduzida quanto ao entupimento dos gotejadores, sugere-se que outras pesquisas investiguem mais detalhadamente o caráter fertilizante da água e os riscos para uso agrícola, incluindo o solo, a planta e o ar.

Pelos dados apresentados nas Tabelas de 10 a 12, os baixos valores de metais pesados indicam que não houve influências de resíduos industriais no efluente da ETE e, por conseqüência, qualquer influência dos mesmos no entupimento dos emissores.

Pelas análises pôde-se comparar a qualidade da água antes e após a passagem nos filtros. Verifica-se que houve retenção de parte dos sólidos 
suspensos, porém os sólidos dissolvidos aumentaram, possivelmente provenientes da fragmentação dos sólidos suspensos durante as retrolavagens ou durante a filtragem pela ação abrasiva da areia. Como conseqüência, notase também um leve incremento no valor de turbidez, a qual é influenciada pelo material dissolvido.

Houve também redução no número de coliformes totais e fecais, demonstrando a influência positiva do filtro de areia na retenção de bactérias, concordando com Gross \& Mitchell ${ }^{8}$ citados por Widrig et al. (1996). Contudo os valores ainda permanecem altos após esse tratamento, necessitando haver cuidados quanto aos grupos de risco e quanto ao entupimento apresentados nas Tabelas 2 e 3, respectivamente.

Há entretanto certa segurança como afirmam Metcalf \& Eddy (2003), pois o sistema de irrigação em questão é um sistema fechado e freqüentemente considerado ideal por esse motivo, minimizando problemas de exposição do produtor irrigante ao efluente e conseqüentemente futuros problemas relacionados a saúde do mesmo, incluindo patógenos, entre eles: bactérias como a Escherichia coli (causadora de diarréia), Salmonella typhy (causadora da febre tifóide) e Vibrio cholerae (causadora da cólera), protozoários como o Cryptosporidium parvum (causador de diarréia), Entamoeba hystolytica (causador de amebíase) e Giardia lamblia (causador de diarréia entre outros sintomas), helmintos como o Ascaris lumbricoides entre outras verminoses conhecidas, e virus como o da hepatite $A$, muitos gastroenterovirus (ex.: Parvovirus, Rotavirus). Sugere-se que outras pesquisas caracterizem o efluente utilizado quanto a esses patógenos que possivelmente ainda permanecem na água após o sistema de filtragem.

Os filtros atuaram na redução em $25 \%$ da DBO, indicando a retenção de material orgânico biologicamente degradável. Esta retenção evitou maiores crescimentos bacterianos no sistema de irrigação, principalmente pelo uso do 
filtro de areia. Adin \& Sacks (1991) também fizeram um comparativo da qualidade medida antes e depois da filtragem, utilizando água residuária. Estes autores também encontraram reduções de DBO ao redor de $24 \%$ e acrécimos na turbidez.

A redução em até $48 \%$ da DQO indica a retenção de material orgânico quimicamente degradável pelo filtro de areia, que também poderiam interferir favoravelmente ao entupimento dos emissores. Em contraposição, o sistema de filtragem praticamente não afetou os valores de condutividade elétrica, $\mathrm{pH}$, macronutrientes, micronutrientes ou metais pesados. Isto é esperado, pois a areia atua como material inerte e os elementos a que se refere apresentam-se na fração dissolvida que passa pelo sistema de filtragem.

Não há possibilidade de entupimento relacionado aos teores de cálcio, magnésio e sódio, pois a soma do teor dos mesmos não ultrapassa 8,23 meq L ${ }^{-1}$ e o cálcio não atinge $6 \mathrm{meq} \mathrm{L}^{-1}\left(240 \mathrm{mg} \mathrm{L}^{-1}\right)$ indicados por Ayers \& Westcot (1999) como problemáticos quanto a precipitação de carbonatos e fertilizantes fosfatados, respectivamente.

\subsubsection{Coeficiente de variação de vazão}

As Tabelas 17 e 18 mostram os coeficientes de variação de vazão a partir das avaliações de vazão efetuadas em todos os gotejadores após 15,80; 37,81 e 52,15 horas de irrigação com a água residuária utilizada.

Os valores médios mostrados foram estatisticamente iguais, indicando que, independente do modelo de gotejador ou manejo adotado, o coeficiente de variação de vazão não varia. É importante comentar que ao se analisar a distribuição dos dados de variação de vazão, anteriormente ao teste $F$, verificou-se que os mesmos não seguiam uma distribuição normal. Assim, foi necessário efetuar a transformação dos dados pelo cálculo do logaritmo na

${ }^{8}$ GROSS, M.; MITCHELL, D. Biological virus removal from household septic effluents. In : NATIONAL SYMPOSIUM ON INDIVIDUAL AND SMALL COMMUNITY SEPTIC SYSTEMS, 4.,New Orleans. Proceedings. St.Joseph: Michigan:ASAE, 1984. p.273-284. 
base neperiana dos valores dos coeficientes de variação de vazão e, posteriormente, proceder à análise de variância e ao teste de comparação de médias com os dados transformados.

Pela Tabela 17, nota-se que os modelos $M$ e $E$ se comportam aparentemente como piores emissores após 52,15 horas de irrigação quando utilizado o tratamento controle. Isto era esperado, pois às 373 horas de aplicação de água residuária, na segunda etapa, os mesmos modelos apresentaram coeficientes de variação de vazão acima de 20 \%.

Tabela 17. Valores de coeficiente de variação de vazão (\%) em diferentes tipos de manejo versus modelos de gotejador após a irrigação com água residuária para três avaliações completas de vazão realizadas na terceira etapa

\begin{tabular}{ccccc}
\hline Tipo de & Modelo de & \multicolumn{3}{c}{ Tempo total irrigado (horas) } \\
\cline { 2 - 5 } manejo & gotejador & 15,80 & 37,81 & 52,15 \\
\hline \multirow{4}{*}{ Controle } & $\mathrm{M}$ & $4,61 \mathrm{a}$ & $21,75 \mathrm{a}$ & $28,77 \mathrm{a}$ \\
& $\mathrm{E}$ & $8,49 \mathrm{a}$ & $10,22 \mathrm{a}$ & $22,93 \mathrm{a}$ \\
& $\mathrm{D}$ & $6,84 \mathrm{a}$ & $11,35 \mathrm{a}$ & $12,69 \mathrm{a}$ \\
& $\mathrm{B}$ & $11,43 \mathrm{a}$ & $21,97 \mathrm{a}$ & $21,80 \mathrm{a}$ \\
Cloração & $\mathrm{M}$ & $3,84 \mathrm{a}$ & $9,69 \mathrm{a}$ & $8,88 \mathrm{a}$ \\
& $\mathrm{E}$ & $5,97 \mathrm{a}$ & $10,61 \mathrm{a}$ & $11,36 \mathrm{a}$ \\
& $\mathrm{D}$ & $7,36 \mathrm{a}$ & $24,96 \mathrm{a}$ & $17,65 \mathrm{a}$ \\
& $\mathrm{B}$ & $4,64 \mathrm{a}$ & $7,99 \mathrm{a}$ & $12,96 \mathrm{a}$ \\
Ar comprimido & $\mathrm{M}$ & $6,75 \mathrm{a}$ & $12,18 \mathrm{a}$ & $18,84 \mathrm{a}$ \\
& $\mathrm{E}$ & $5,35 \mathrm{a}$ & $15,88 \mathrm{a}$ & $17,58 \mathrm{a}$ \\
& $\mathrm{D}$ & $5,76 \mathrm{a}$ & $20,34 \mathrm{a}$ & $22,29 \mathrm{a}$ \\
& $\mathrm{B}$ & $6,20 \mathrm{a}$ & $12,15 \mathrm{a}$ & $12,64 \mathrm{a}$ \\
Cloração e ar & $\mathrm{M}$ & $8,08 \mathrm{a}$ & $16,19 \mathrm{a}$ & $7,01 \mathrm{a}$ \\
comprimido & $\mathrm{E}$ & $7,16 \mathrm{a}$ & $23,07 \mathrm{a}$ & $30,99 \mathrm{a}$ \\
& $\mathrm{D}$ & $10,21 \mathrm{a}$ & $17,03 \mathrm{a}$ & $13,87 \mathrm{a}$ \\
& $\mathrm{B}$ & $4,22 \mathrm{a}$ & $12,47 \mathrm{a}$ & $17,89 \mathrm{a}$ \\
\hline
\end{tabular}

Médias com mesma letra entre linhas no mesmo tipo de manejo são iguais estatisticamente pelo teste de Tukey a $5 \%$ de significância.

As diferenças encontradas, usualmente com valores de coeficiente de variação de vazão aparentemente superiores nesta terceira etapa, correspondem ao fato de que nesta etapa a aplicação da água estava condicionada ao tempo de irrigação calculado pelo balanço hídrico e ao tempo 
mínimo de aplicação de cloro de 15 minutos, mantendo-se menos tempo de água em movimento em comparação à segunda etapa, a qual se procedia a aplicação do efluente diariamente.

Pela Tabela 18, observa-se que os coeficientes de variação de vazão apresentam-se superiores a $10 \%$ na maioria dos valores analisados e para todos os manejos. O que indicaria que nenhum tratamento foi eficiente em manter os coeficientes ao nível desejável. Isto também ocorre quanto aos modelos testados, ou seja, pela Tabela 17 nota-se valores acima de $10 \%$ em todos os modelos, indicando pouca ação das características destes na manutenção do coeficiente de variação, com exceção do modelo M utilizandose o manejo de cloração.

Tabela 18. Valores de coeficiente de variação de vazão (\%) em diferentes modelos de gotejador versus tipos de manejo após a irrigação com água residuária para três avaliações completas de vazão realizadas na terceira etapa

\begin{tabular}{ccccc}
\hline \multirow{2}{*}{ Modelo de gotejador } & Tipo de manejo & \multicolumn{3}{c}{ Tempo total irrigado (horas) } \\
\cline { 2 - 5 } & Controle & $4,, 80$ & 37,81 & 52,15 \\
\hline \multirow{2}{*}{ M } & Cloração & $3,84 \mathrm{a}$ & $21,75 \mathrm{a}$ & $28,77 \mathrm{a}$ \\
& Ar comprimido & $6,75 \mathrm{a}$ & $12,18 \mathrm{a}$ & $8,88 \mathrm{a}$ \\
& Cloração e ar comprimido & $8,08 \mathrm{a}$ & $16,19 \mathrm{a}$ & $7,01 \mathrm{a}$ \\
& Controle & $8,49 \mathrm{a}$ & $10,22 \mathrm{a}$ & $22,93 \mathrm{a}$ \\
$\mathrm{E}$ & Cloração & $5,97 \mathrm{a}$ & $10,61 \mathrm{a}$ & $11,36 \mathrm{a}$ \\
& Ar comprimido & $5,35 \mathrm{a}$ & $15,88 \mathrm{a}$ & $17,58 \mathrm{a}$ \\
& Cloração e ar comprimido & $7,16 \mathrm{a}$ & $23,07 \mathrm{a}$ & $30,99 \mathrm{a}$ \\
$\mathrm{N}$ & Controle & $6,84 \mathrm{a}$ & $11,35 \mathrm{a}$ & $12,69 \mathrm{a}$ \\
& Cloração & $7,36 \mathrm{a}$ & $24,96 \mathrm{a}$ & $17,65 \mathrm{a}$ \\
& Ar comprimido & $5,76 \mathrm{a}$ & $20,34 \mathrm{a}$ & $22,29 \mathrm{a}$ \\
& Cloração e ar comprimido & $10,21 \mathrm{a}$ & $17,03 \mathrm{a}$ & $13,87 \mathrm{a}$ \\
& Controle & $11,43 \mathrm{a}$ & $21,97 \mathrm{a}$ & $21,80 \mathrm{a}$ \\
$\mathrm{B}$ & Cloração & $4,64 \mathrm{a}$ & $7,99 \mathrm{a}$ & $12,96 \mathrm{a}$ \\
& Ar comprimido & $6,20 \mathrm{a}$ & $12,15 \mathrm{a}$ & $12,64 \mathrm{a}$ \\
& Cloração e ar comprimido & $4,22 \mathrm{a}$ & $12,47 \mathrm{a}$ & $17,89 \mathrm{a}$ \\
\hline
\end{tabular}

Médias com mesma letra entre linhas no mesmo modelo de gotejador são iguais estatisticamente pelo teste de Tukey a $5 \%$ de significância. 
A precipitação pluviométrica (418 mm de fevereiro a agosto de 2003) e a pequena evaporação da água no tanque classe "A" (média de 3,06 $\mathrm{mm} \mathrm{dia}^{-1}$ ), cuja distribuição se encontra na Figura 16, somados à necessidade de se esperar o tempo mínimo para aplicação da solução clorada, conduziram a paradas mais prolongadas que as paradas consideradas na fase de seleção de emissores. Isto pode ter favorecido ao elevado coeficiente de variação de vazão.

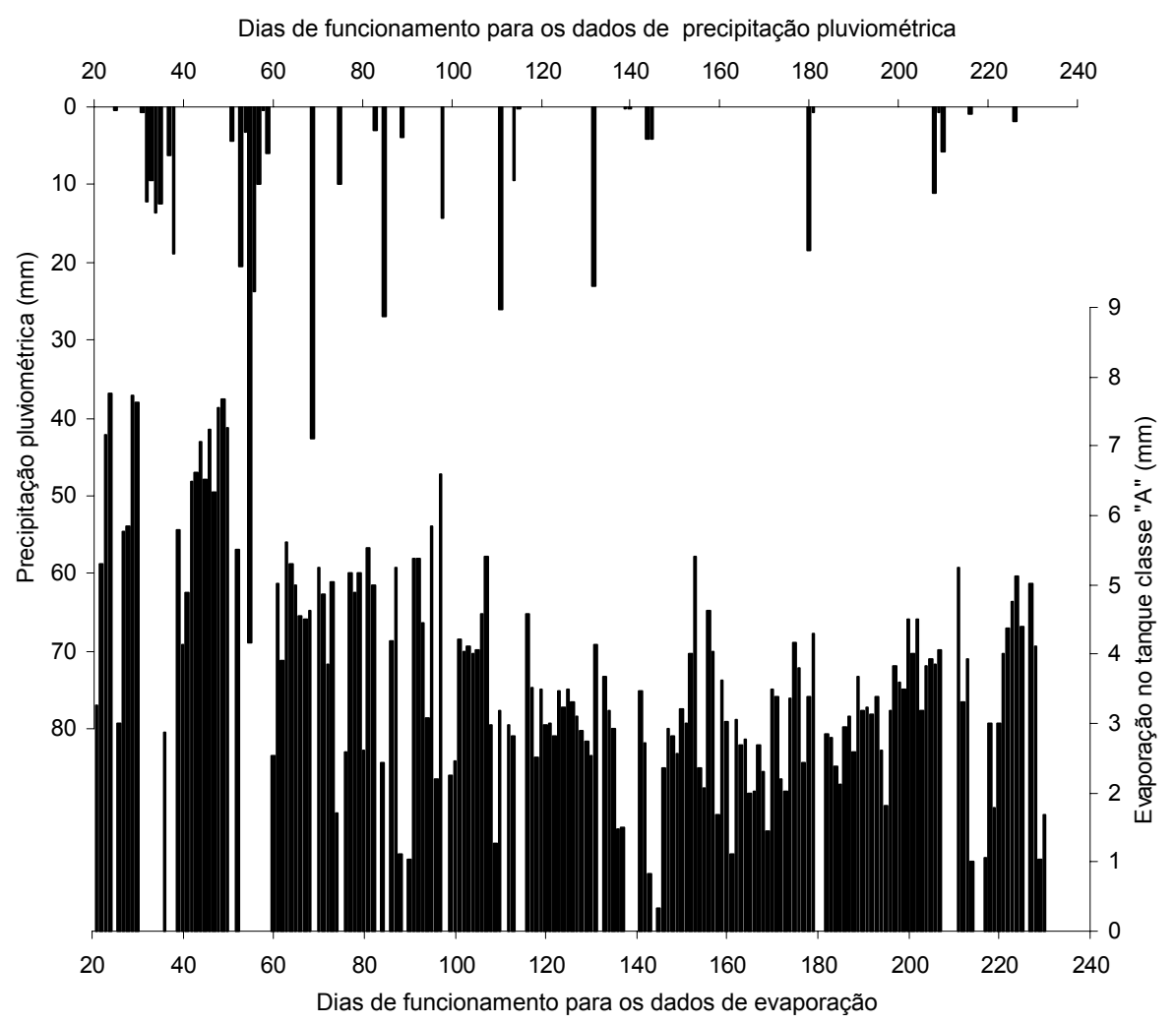

Figura 16 - Representação gráfica dos dados diários da precipitação pluviométrica e da evaporação de água no tanque classe "A", ocorridos durante a terceira etapa

Na Figura 16 também verifica-se dados apenas a partir de 20 dias do início do experimento. Isto justifica-se porque os primeiros 20 dias (12 de janeiro a 31 de janeiro) corresponderam ao tempo para ajuste da metodologia empregada, não procedendo registro dos dados climáticos nesse período. 
Em resumo, os resultados indicam que não houve tratamentos estatisticamente melhores ou piores quanto aos valores médios de coeficiente de variação de vazão, ou seja,dentre os tipos de manejos estudados, é melhor utilizar a filtragem, pois é uma técnica tradicional em sistemas de irrigação localizada e não requer custos adicionais.

Devido a elevada variabilidade dos dados, outros critérios devem ser analisados em conjunto para se definir as melhores combinações de gotejador e manejo, incluindo o grau de entupimento e a análise probabilística das vazões.

\subsubsection{Grau de entupimento}

As Tabelas 19 e 20 mostram os graus de entupimento a partir das avaliações de vazão efetuadas em todos os gotejadores após 15,80; 37,81 e 52,15 horas de irrigação com a água residuária utilizada. Os graus de entupimento para cada emissor, resultantes de todas as avaliações de vazão, podem ser visualizados nos Anexos de D a S.

Conforme visualizado na Tabela 19, não houve diferenças estatísticas entre os modelos testados nos tipos de manejo correspondentes ao uso de somente filtros ou àqueles em que se incluiu o ar comprimido. Isto sugere o uso de qualquer modelo de gotejador quando se utilizam estes manejos. Com o uso de apenas cloração, sugere-se o uso dos modelos $M, E$ e B, pois o modelo $D$ apresentou grau de entupimento estatisticamente superior aos demais.

Pela Tabela 20 nota-se que os manejos não foram estatisticamente diferentes entre si (com exceção para o modelo $D$ às 37,81 horas), o que sugere o uso de apenas filtragem em relação aos demais, pois como dito anteriormente, é uma técnica tradicional em sistemas de irrigação localizada e não requer custos adicionais. Porém, conforme visualizado na Tabela 19, os valores de grau de entupimento superiores a $5 \%$ (possivelmente devido ao fato dos filtros permitirem a passagem de sólidos dissolvidos, de enxofre e de 
bactérias formadoras de mucilagem para tubulação e emissores) encontrados nos gotejadores não-autocompensantes do manejo controle, indicam que pelo menos estes, precisam de tratamentos complementares.

Tabela 19. Graus de entupimento (\%) em diferentes tipos de manejo versus modelos de gotejador após a irrigação com água residuária para três avaliações completas de vazão na terceira etapa do trabalho

\begin{tabular}{ccccc}
\hline Tipo de & Modelo de & \multicolumn{3}{c}{ Tempo total irrigado (horas) } \\
\cline { 3 - 5 } manejo & gotejador & 15,80 & 37,81 & 52,15 \\
\hline \multirow{4}{*}{ Controle } & $\mathrm{M}$ & $3,19 \mathrm{a}$ & $4,32 \mathrm{a}$ & $5,47 \mathrm{a}$ \\
& $\mathrm{E}$ & $8,79 \mathrm{a}$ & $5,48 \mathrm{a}$ & $6,43 \mathrm{a}$ \\
& $\mathrm{D}$ & $12,69 \mathrm{a}$ & $10,44 \mathrm{a}$ & $7,54 \mathrm{a}$ \\
& $\mathrm{B}$ & $3,40 \mathrm{a}$ & $7,89 \mathrm{a}$ & $1,86 \mathrm{a}$ \\
Cloração & $\mathrm{M}$ & $7,98 \mathrm{~b}$ & $1,03 \mathrm{~b}$ & $-0,39 \mathrm{~b}$ \\
& $\mathrm{E}$ & $11,98 \mathrm{ab}$ & $3,81 \mathrm{~b}$ & $-4,65 \mathrm{~b}$ \\
& $\mathrm{D}$ & $18,12 \mathrm{a}$ & $17,43 \mathrm{a}$ & $8,14 \mathrm{a}$ \\
& $\mathrm{B}$ & $6,27 \mathrm{~b}$ & $1,50 \mathrm{~b}$ & $0,89 \mathrm{~b}$ \\
Ar comprimido & $\mathrm{M}$ & $5,76 \mathrm{ab}$ & $-4,93 \mathrm{a}$ & $4,17 \mathrm{a}$ \\
& $\mathrm{E}$ & $7,06 \mathrm{ab}$ & $-3,71 \mathrm{a}$ & $1,33 \mathrm{a}$ \\
& $\mathrm{D}$ & $14,32 \mathrm{a}$ & $6,97 \mathrm{a}$ & $11,48 \mathrm{a}$ \\
& $\mathrm{B}$ & $4,81 \mathrm{~b}$ & $6,49 \mathrm{a}$ & $3,16 \mathrm{a}$ \\
Cloração e ar & $\mathrm{M}$ & $4,83 \mathrm{~b}$ & $-2,11 \mathrm{a}$ & $-5,18 \mathrm{a}$ \\
comprimido & $\mathrm{E}$ & $3,84 \mathrm{~b}$ & $0,14 \mathrm{a}$ & $5,62 \mathrm{a}$ \\
& $\mathrm{D}$ & $17,52 \mathrm{a}$ & $5,43 \mathrm{a}$ & $10,37 \mathrm{a}$ \\
& $\mathrm{B}$ & $5,27 \mathrm{~b}$ & $6,30 \mathrm{a}$ & $4,67 \mathrm{a}$ \\
\hline
\end{tabular}

Médias com mesma letra entre linhas no mesmo tipo de manejo são iguais estatisticamente pelo teste de Tukey a $5 \%$ de significância.

No caso de uso de somente filtragem, seria aconselhável adotar o modelo auto-limpante (B), pois este foi o que apresentou, aparentemente, o menor valor médio para o grau de entupimento $(1,86 \%)$ às 52,15 horas de irrigação. Contudo, outros fatores devem ser considerados para a escolha do modelo, tais como o coeficiente de variação de vazão e os resultados de probabilidade de se encontrar emissores próximos a vazão do emissor quando novo. 
Tabela 20. Graus de entupimento (\%) em diferentes tipos de manejo versus modelos de gotejador após a irrigação com água residuária para três avaliações completas de vazão na terceira etapa do trabalho

\begin{tabular}{ccccc}
\hline \multirow{2}{*}{ Modelo de gotejador } & Tipo de manejo & \multicolumn{3}{c}{ Tempo total irrigado (horas) } \\
\cline { 2 - 5 } & 15,80 & 37,81 & 52,15 \\
\hline \multirow{2}{*}{ M } & Controle & $3,19 \mathrm{a}$ & $4,32 \mathrm{a}$ & $5,47 \mathrm{a}$ \\
& Cloração & $7,98 \mathrm{a}$ & $1,03 \mathrm{a}$ & $-0,39 \mathrm{a}$ \\
& Ar comprimido & $5,76 \mathrm{a}$ & $-4,93 \mathrm{a}$ & $4,17 \mathrm{a}$ \\
& Cloração e ar comprimido & $4,83 \mathrm{a}$ & $-2,11 \mathrm{a}$ & $-5,18 \mathrm{a}$ \\
$\mathrm{E}$ & Controle & $8,79 \mathrm{a}$ & $5,48 \mathrm{a}$ & $6,43 \mathrm{a}$ \\
& Cloração & $11,98 \mathrm{a}$ & $3,81 \mathrm{a}$ & $-4,65 \mathrm{a}$ \\
& Ar comprimido & $7,06 \mathrm{a}$ & $-3,71 \mathrm{a}$ & $1,33 \mathrm{a}$ \\
& Cloração e ar comprimido & $3,84 \mathrm{a}$ & $0,14 \mathrm{a}$ & $5,62 \mathrm{a}$ \\
$\mathrm{D}$ & Controle & $12,69 \mathrm{a}$ & $10,44 \mathrm{ab}$ & $7,54 \mathrm{a}$ \\
& Cloração & $18,12 \mathrm{a}$ & $17,43 \mathrm{a}$ & $8,14 \mathrm{a}$ \\
& Ar comprimido & $14,32 \mathrm{a}$ & $6,97 \mathrm{~b}$ & $11,48 \mathrm{a}$ \\
& Cloração e ar comprimido & $17,52 \mathrm{a}$ & $5,43 \mathrm{~b}$ & $10,37 \mathrm{a}$ \\
& Controle & $3,40 \mathrm{a}$ & $7,89 \mathrm{a}$ & $1,86 \mathrm{a}$ \\
$\mathrm{B}$ & Cloração & $6,27 \mathrm{a}$ & $1,50 \mathrm{a}$ & $0,89 \mathrm{a}$ \\
& Ar comprimido & $4,81 \mathrm{a}$ & $6,49 \mathrm{a}$ & $3,16 \mathrm{a}$ \\
& Cloração e ar comprimido & $5,27 \mathrm{a}$ & $6,30 \mathrm{a}$ & $4,67 \mathrm{a}$ \\
\hline
\end{tabular}

Médias com mesma letra entre linhas no mesmo modelo de gotejador são iguais estatisticamente pelo teste de Tukey a $5 \%$ de significância.

Com exceção do modelo $D$, aparentemente notam-se menores graus de entupimento aplicando-se a solução clorada. Isto poderia ser um motivo para se estudar dosagens que proporcionem maiores níveis de cloro residual livre ao final do sistema, ou seja, superior a $0,5 \mathrm{mg} \mathrm{L}^{-1}$, porém não atingindo valores tal como o de $300 \mathrm{mg} \mathrm{L}^{-1}$ encontrado no trabalho de Resende (1999), que é recomendado apenas para recuperação de emissores. A redução do $\mathrm{pH}$ por adição de ácidos e a aplicação anterior ao sistema de filtragem poderiam também auxiliar na prevenção mais eficiente ao entupimento dos emissores.

Além disto, fatores econômicos e ambientais devem ser considerados na escolha do nível de cloro residual livre. Para $0,5 \mathrm{mg} \mathrm{L}^{-1}$ os problemas associados ao meio ambiente são mínimos, pois o nível máximo permissível de cloretos na água segundo Ayers \& Westcot (1999) é de $237,52 \mathrm{mg} \mathrm{L}^{-1}$ $\left(6,7 \mathrm{meq} \mathrm{L}^{-1}\right)$ para a cultura de tangerina utilizada, e o custo é aproximadamente 
o custo de $690 \mathrm{~L} \mathrm{ha}^{-1}$ de hipoclorito de sódio acrescido do custo do equipamento para injeção. Para este experimento, fez-se uma adaptação em um tanque de injeção de fertilizantes, ou seja, usou-se um saco plástico no interior do mesmo, de forma que o produto era aplicado a taxa constante sob a transferência de energia hidráulica do meio externo ao plástico, contendo a solução clorada à concentração de $20 \mathrm{mg} \mathrm{L}^{-1}$. Desta forma, o custo foi relativamente baixo, comparado à aquisição de bombas injetoras ou ao uso de outros dispositivos sujeitos à corrosão.

Os manejos com ar comprimido não se mostraram eficientes na minimização do grau de entupimento. Possivelmente a baixa pressão de ar $(1,96 \mathrm{kPa})$ não foi suficiente para expelir partículas e a vazão de ar (máximo de $1 \mathrm{~L} \mathrm{~s}^{-1}$ por manejo) não foi suficiente para secar totalmente as adutoras e tubulações secundárias, permitindo a formação da mucilagem que foi observada visualmente. Contudo, em certos momentos, nos gotejadores nãoautocompensantes, ocorreram aparentes reduções no grau de entupimento, particularmente da primeira para a segunda avaliação completa. Ravina et al. (1992), por recomendação de fabricantes, aplicaram um tratamento de ar a dois modelos de emissor sem regulação automática da pressão, também obtiveram melhora em certo período (após o inverno), porém; os mesmos não fornecem detalhes da aplicação, tais como a pressão e tempo de funcionamento do compressor. Estes autores citam que após o longo período de inverno, os depósitos no interior dos emissores secaram e foram lavados facilmente pela água quando o sistema de irrigação voltou a operar.

Quanto à ação ao longo do tempo, nota-se pela Tabela 21 que, estatisticamente, a mesma ocorreu apenas para os modelos nãoautocompensantes sob o tratamento de cloração, embora o modelo $\mathrm{D}$ ainda apresente entupimento de $8,14 \%$ a 52,15 horas, como observado na Tabela 19. Portanto, há auxílio da cloração para reduzir o entupimento ao longo do tempo nos modelos não auto-limpantes. Como explicação auxiliar ao fato dessa recuperação de emissores têm-se que entupimentos iniciais, 
anteriormente aos 20 dias de início do experimento (tempo utilizado no ajuste das metodologias) podem ter ocorrido, originando os valores de grau de entupimento observados na primeira avaliação de vazão completa. Portanto, além de caráter preventivo, percebe-se que alguns tratamentos, como a cloração, mesmo a baixa concentração, pode ter efeitos de recuperação após certo período.

Tabela 21. Resultado da análise de regressão para grau de entupimento (GE) em função do período em que a terceira etapa foi conduzida ( $t$ )

\begin{tabular}{cccc}
\hline Tipo de manejo & Modelo de gotejador & \multicolumn{1}{c}{$\begin{array}{c}\mathrm{GE}=\mathrm{at}+\mathrm{b} \\
\mathrm{GE}(\%) \mathrm{et}(\mathrm{dias})\end{array}$} \\
\hline \multirow{3}{*}{ Controle } & $\mathrm{M}$ & $+0,0136 \mathrm{t}+2,3152 \mathrm{NS}$ \\
& $\mathrm{E}$ & $-0,0148 \mathrm{t}+9,081$ & $\mathrm{NS}$ \\
& $\mathrm{D}$ & $-0,0307 \mathrm{t}+14,751$ & $\mathrm{NS}$ \\
Cloração & $\mathrm{B}$ & $-0,0076 \mathrm{t}+5,5064$ & $\mathrm{NS}$ \\
& $\mathrm{M}$ & $-0,0509 \mathrm{t}+10,387$ & $* *$ \\
& $\mathrm{E}$ & $-0,0993 \mathrm{t}+18,38$ & $* *$ \\
Ar comprimido & $\mathrm{D}$ & $-0,0583 \mathrm{t}+23,167$ & $*$ \\
& $\mathrm{~B}$ & $-0,0328 \mathrm{t}+7,7353 \mathrm{NS}$ \\
& $\mathrm{M}$ & $-0,0126 \mathrm{t}+3,5237 \mathrm{NS}$ \\
& $\mathrm{E}$ & $-0,0367 \mathrm{t}+6,9807 \mathrm{NS}$ \\
Cloração e ar comprimido & $\mathrm{D}$ & $-0,0188 \mathrm{t}+13,707 \mathrm{NS}$ \\
& $\mathrm{B}$ & $-0,0091 \mathrm{t}+6,1581 \mathrm{NS}$ \\
& $\mathrm{M}$ & $-0,0604 \mathrm{t}+8,0991$ & $*$ \\
& $\mathrm{E}$ & $+0,0092 \mathrm{t}+1,8424 \mathrm{NS}$ \\
& $\mathrm{D}$ & $-0,0454 \mathrm{t}+17,806 \mathrm{NS}$ \\
& $\mathrm{B}$ & $-0,0031 \mathrm{t}+5,8788 \mathrm{NS}$ \\
\hline
\end{tabular}

NS - não significativo estatisticamente

* - significativo a $5 \%$ pelo teste $\mathrm{F}$

** - significativo a $1 \%$ pelo teste $\mathrm{F}$

\subsubsection{Análise probabilística da vazão dos gotejadores}

Os resultados apresentados na Tabela 22, obtidos a partir do Anexo T, indicam o modelo $\mathrm{B}$ como o melhor, pois apresentou maiores probabilidades de se encontrar valores de vazão na faixa de variação de $\pm 5 \%$ em relação à vazão média dos mesmos quando novos. Além disso, este modelo apresentou 
aumento no número estimado de gotejadores nessa faixa considerada aceitável, quando aplicado o tratamento de cloração. Isso também foi percebido quando se utilizou o tratamento combinado (cloração e ar comprimido); porém, a cloração quando realizada apenas com filtragem foi suficiente, não havendo necessidade da adição do tratamento de ar comprimido a esse modelo, pois as probabilidades foram praticamente iguais ou superiores ao tratamento combinado em duas das três avaliações completas. Portanto, a membrana compensadora de pressão localizada no interior do gotejador atua mais eficientemente na limpeza do emissor quando submetida a algum tratamento. Porém, concentrações elevadas de cloro podem causar o desgaste prematuro da membrana, causando aumentos de vazão. Assim, é necessário cautela nos manejos a serem adotados para se evitar o entupimento ou a perda de vida útil dos emissores.

No caso deste experimento, usando a concentração de $0,5 \mathrm{mg} \mathrm{L}^{-1}$, a maioria dos valores fora da faixa de $\pm 5 \%$ se encontraram abaixo da mesma, mostrando entupimento e não aumento de vazão.

Os modelos considerados piores na segunda etapa, também tiveram baixo desempenho nesta etapa, obtendo menos de $50 \%$ de probabilidade de se encontrar emissores na faixa considerada.

$\mathrm{O}$ uso de cloração com filtragem permite melhores resultados para o modelo M (70 \% a 37,81 horas e $60 \%$ a 52,15 horas de irrigação). O uso de ar comprimido ou este combinado com a cloração reduziu a probabilidade de se encontrar gotejadores na faixa de variação considerada, sugerindo não ser recomendado a utilização deste tratamento para o modelo $\mathrm{M}$.

A cloração e a aplicação do ar comprimido isoladamente auxiliaram na minimização do entupimento no modelo $\mathrm{E}$ com mais de $50 \%$ de emissores com menos de $5 \%$ de variação. Por outro lado, o efeito combinado dos tratamentos com cloro e ar não é aconselhável, pois menos emissores se apresentam na faixa de variação considerada aceitável em relação ao tratamento realizado apenas com filtragem. 
O modelo $D$ apresentou bons resultados apenas às 37,81 horas para os tratamentos com ar comprimido.

Para o modelo M é recomendável o uso de cloração isoladamente. Para o modelo D não é recomendável o uso do ar comprimido. Para o modelo $E$, não é interessante a combinação de ar comprimido e cloração. O modelo $B$ se comporta bem isoladamente, mas a cloração aumenta o número de emissores em condição aceitável de vazão.

Tabela 22. Probabilidades (\%) de encontrar gotejadores com vazão na faixa de variacão de $\pm 5 \%$ em relação à vazão média dos mesmos quando novos, após a irrigação com água residuária para três avaliações completas de vazão realizadas na terceira etapa do trabalho

\begin{tabular}{ccccc}
\hline Tipo de & Modelo de & \multicolumn{3}{c}{ Tempo total irrigado (horas) } \\
\cline { 3 - 5 } manejo & gotejador & 15,80 & 37,81 & 52,15 \\
\hline \multirow{4}{*}{ Controle } & M & 55 & 40 & 38 \\
& E & 20 & 45 & 48 \\
& D & 5 & 30 & 56 \\
Cloração & B & 65 & 45 & 60 \\
& $\mathrm{M}$ & 45 & 70 & 60 \\
& $\mathrm{E}$ & 15 & 57 & 53 \\
& $\mathrm{D}$ & 0 & 16 & 55 \\
Ar comprimido & $\mathrm{B}$ & 50 & 83 & 73 \\
& $\mathrm{M}$ & 61 & 34 & 35 \\
& $\mathrm{E}$ & 30 & 40 & 58 \\
& $\mathrm{D}$ & 1 & 68 & 49 \\
Cloração e ar & $\mathrm{B}$ & 60 & 65 & 62 \\
comprimido & $\mathrm{M}$ & 20 & 28 & 34 \\
& $\mathrm{E}$ & 22 & 27 & 43 \\
& $\mathrm{D}$ & 3 & 75 & 54 \\
& $\mathrm{~B}$ & 46 & 74 & 74 \\
\hline
\end{tabular}

Em resumo, pela análise de probabilidades identificou-se a cloração com o modelo $\mathrm{B}$ como a melhor combinação e o modelo $\mathrm{M}$ com apenas filtragem ou com os tratamentos de ar comprimido, como as piores combinações.

Aliado a análise de probabilidades, verificou-se a percentagem de emissores com vazão inferior ou igual a 50 \% da vazão dos mesmos quando 
novos (considerado entupidos por Adin \& Sacks, 1991), como pode ser observado na Tabela 23. Nota-se que a percentagem de emissores com vazões inferiores a $50 \%$ apresentam tendência de aumento ao longo do tempo, porém não detectado plenamente no manejo com cloração isoladamente. O manejo com efeito combinatório de cloro e ar comprimido oscila, isto provavelmente devido a ação do ar comprimido, que em efeito isolado apresentou aumento em todos os modelos de gotejador, e da cloração, que isoladamente e, aparentemente, apresenta uma resistência a obstrução parcial (inferior a 50 \%).

No caso de emissores com $100 \%$ de entupimento, a cloração permitiu a não obstrução dos modelos $\mathrm{M} \mathrm{e} \mathrm{E}$, e os manejos de ar comprimido e o controle mantiveram a obstrução em 1,33 \% dos emissores. Este valor é inferior a $10 \%$, que é um valor sugerido por Coelho $^{9}$ como limitante a produtividade das culturas, porém pode acarretar em aumento da pressão do sistema. Fato este, não constatado neste trabalho, pois a cada irrigação efetuava-se a regulagem da pressão por ação manual de um registro de agulha, fechando-o completamente depois de terminado o tempo de irrigação. Além disso, as bombas de água permitiram o fornecimento da pressão sem ocorrer aquecimentos desnecessários e que comprometessem o funcionamento das mesmas.

${ }^{9}$ COELHO, R. D. (ESALQ, Departamento de Engenharia Rural) - Informação pessoal, 2004. 
Tabela 23. Percentagem de emissores com vazão inferior a metade da vazão quando novos (qusado $\leq 0,5$ qnovo) e completamente entupidos $(\mathrm{GE}=100 \%)$, após a irrigação com água residuária para três avaliações completas de vazão realizadas na terceira etapa

\begin{tabular}{|c|c|c|c|c|c|c|c|}
\hline \multirow[t]{2}{*}{$\begin{array}{l}\text { Tipos de } \\
\text { manejo }\end{array}$} & \multirow[t]{2}{*}{$\begin{array}{l}\text { Modelos de } \\
\text { gotejador }\end{array}$} & \multicolumn{3}{|c|}{$\begin{array}{c}\text { qusado } \leq 0,5 \mathrm{q}_{\text {novo }} \\
\text { Tempo total } \\
\text { irrigado }(\mathrm{h})\end{array}$} & \multicolumn{3}{|c|}{$\begin{array}{l}\text { GE }=100 \% \\
\begin{array}{l}\text { Tempo total } \\
\text { irrigado }(\mathrm{h})\end{array}\end{array}$} \\
\hline & & 15,80 & 37,81 & 52,15 & 15,80 & 37,81 & 52,15 \\
\hline \multirow{4}{*}{ Controle } & M & 0 & 1,33 & 5,33 & 0 & 1,33 & 1,33 \\
\hline & $E$ & 0 & 1,33 & 6,67 & 0 & 0 & 1,33 \\
\hline & D & 0 & 2,67 & 1,33 & 0 & 0 & 1,33 \\
\hline & B & 1,33 & 5,33 & 2,67 & 1,33 & 1,33 & 1,33 \\
\hline \multirow{4}{*}{ Cloração } & M & 0 & 1,33 & 1,33 & 0 & 0 & 0 \\
\hline & $E$ & 0 & 1,33 & 0 & 0 & 1,33 & 0 \\
\hline & D & 0 & 4 & 1,33 & 0 & 1,33 & 1,33 \\
\hline & B & 0 & 0 & 1,33 & 0 & 0 & 1,33 \\
\hline \multirow{4}{*}{ Ar comprimido } & M & 0 & 1,33 & 1,33 & 0 & 1,33 & 1,33 \\
\hline & $E$ & 0 & 2,67 & 4 & 0 & 1,33 & 1,33 \\
\hline & D & 0 & 4 & 6,67 & 0 & 1,33 & 1,33 \\
\hline & B & 1,33 & 1,33 & 2,67 & 0 & 1,33 & 0 \\
\hline \multirow{4}{*}{$\begin{array}{l}\text { Cloração e ar } \\
\text { comprimido }\end{array}$} & M & 1,33 & 2,67 & 0 & 0 & 1,33 & 0 \\
\hline & $E$ & 1,33 & 5,33 & 4 & 0 & 1,33 & 1,33 \\
\hline & D & 4 & 2,67 & 4 & 0 & 1,33 & 1,33 \\
\hline & B & 0 & 2,67 & 1,33 & 0 & 1,33 & 1,33 \\
\hline
\end{tabular}

\subsubsection{Sugestões para trabalhos futuros}

Os resultados encontrados sugerem que seria necessário novos estudos relacionados à concentração de cloro residual livre e à pressão de ar comprimido possivelmente superiores aos valores utilizados neste trabalho para prevenção de entupimento de gotejadores utilizados com água residuária.

A abertura de linhas para limpeza e a descarga de sólidos dissolvidos que se depositam ao final das mesmas é uma técnica interessante para minimizar o entupimento, mas novos estudos poderiam indicar as melhores freqüências para a aplicação desta prática de acordo com a operacionalidade em campo. Análises de custo de mão de obra e a possibilidade da adição de 
válvulas de descarga automática ao final das linhas também poderiam ser avaliadas.

Aos fabricantes de gotejadores, sugere-se o desenvolvimento de novos emissores com características semelhantes aos que apresentaram melhor desempenho neste trabalho, para uso com águas residuárias. Porém, é também interessante aos fabricantes se basearem em novos estudos que sejam realizados com efluentes de ETEs distintos (também originados de esgoto doméstico), assegurando a produção de emissores mais especializados às condições de qualidade de água e de manejo utilizados.

Novas pesquisas envolvendo a prática da filtragem incluindo estudos em filtros de areia, de disco e de tela, sejam eles auto-limpantes ou nãoautolimpantes, devem ser realizadas para torná-la cada vez mais eficiente, prática, conveniente e econômica. Além disso, sugere-se investigar detalhadamente os aumentos de vazão que podem ocorrer em gotejadores pelo uso de águas residuárias. 


\section{CONCLUSÕES}

De acordo com os objetivos propostos, resultados obtidos e condições presentes neste trabalho, têm-se as seguintes conclusões:

-- Os modelos de gotejador apresentaram entupimento parcial com a aplicação de água residuária oriunda de tratamento secundário de estação de tratamento de esgoto, ocorrendo em todo o interior dos emissores, com maior incidência em cantos e paredes do labirinto;

-- O entupimento reduziu a uniformidade de distribuição da água a valores inferiores a $60 \%$ e aumentou os coeficientes de variação de vazão a valores superiores a $20 \%$ em alguns modelos de gotejador, mesmo em emissores com excelentes coeficientes de variação de vazão quando novos;

-- Comprimentos de passagem de água longos, presença de regiões com regime laminar, pequenas vazões, ineficiência de mecanismo auto-limpante, pequena velocidade da água na linha e seções estreitas favoreceram ao entupimento pelo uso de água residuária;

-- A cloração reduziu o grau de entupimento ao longo do tempo para modelos de gotejador não auto-compensantes e evitou o entupimento total em emissores; 
-- Todos os tipos de manejo preventivos ao entupimento foram estatisticamente semelhantes entre si para o grau de entupimento e o coeficiente de variação de vazão;

-- Na condição de água residuária com tratamentos adicionais, o modelo de gotejador B com o uso da técnica de cloração apresentou a maior probabilidade de encontrar emissores na faixa de $5 \%$ de variação de vazão em relação às demais combinações;

-- A combinação do modelo de gotejador $\mathrm{M}$ aliado à filtragem isoladamente ou aos tratamentos com ar comprimido apresentou as menores probabilidades de encontrar emissores na faixa de $5 \%$ de variação de vazão em relação aos mesmos quando novos;

-- A concentração do cloro residual livre e a pressão de ar comprimido utilizados foram insuficientes para a prevenção desejada ao entupimento ocorrido, o qual atingiu valores de grau de entupimento superiores a $5 \%$; e

-- O modelo B associado à cloração foi a combinação que melhor atenuou o entupimento. 
ANEXOS 
Anexo A - Graus de entupimento dos modelos de gotejadores testados, obtidos a partir de três avaliações de vazão amostrais, depois da aplicação de água residuária realizada na segunda etapa

\begin{tabular}{|c|c|c|c|c|c|c|c|c|}
\hline \multirow{3}{*}{ Modelo de gotejador } & \multirow{3}{*}{ Horas de aplicação } & \multicolumn{6}{|c|}{ Posição do gotejador } & \multirow{3}{*}{ média } \\
\hline & & \multicolumn{3}{|c|}{ Linha 1} & \multicolumn{3}{|c|}{ Linha 2} & \\
\hline & & 4 & 13 & 21 & 4 & 13 & 21 & \\
\hline \multirow{3}{*}{$A$} & 97 & 2,67 & $-0,54$ & 9,89 & $-1,66$ & 5,44 & 0,33 & 2,69 \\
\hline & 198 & 2,39 & 8,65 & 9,68 & 1,37 & 15,88 & 10,28 & 8,04 \\
\hline & 300 & 10,88 & 14,40 & 16,60 & 4,64 & 10,35 & 11,94 & 11,47 \\
\hline \multirow{3}{*}{$B$} & 97 & 8,93 & $-0,18$ & 3,12 & 1,64 & 0,22 & $-3,94$ & 1,63 \\
\hline & 198 & $-1,75$ & 0,36 & $-13,31$ & $-7,62$ & $-0,25$ & $-8,14$ & $-5,12$ \\
\hline & 300 & $-3,54$ & $-10,62$ & $-4,99$ & 2,15 & $-11,52$ & $-8,18$ & $-6,12$ \\
\hline \multirow{3}{*}{ C } & 97 & 3,81 & 6,40 & 5,91 & 8,35 & 1,54 & $-0,63$ & 4,23 \\
\hline & 198 & 0,86 & 10,18 & 3,45 & 3,85 & 2,99 & $-0,53$ & 3,47 \\
\hline & 300 & 2,18 & 8,80 & 15,38 & 7,15 & 8,50 & 5,30 & 7,89 \\
\hline \multirow{3}{*}{$\mathrm{D}$} & 97 & 15,76 & 13,91 & 0,66 & 2,69 & 13,07 & 8,70 & 9,13 \\
\hline & 198 & 8,94 & $-1,88$ & $-4,15$ & $-1,21$ & 2,18 & 1,66 & 0,93 \\
\hline & 300 & 7,85 & $-3,39$ & $-3,25$ & $-5,58$ & 5,08 & 2,37 & 0,51 \\
\hline \multirow{3}{*}{$E$} & 97 & $-9,96$ & $-5,03$ & $-5,72$ & 9,35 & $-6,71$ & $-7,87$ & $-4,32$ \\
\hline & 198 & $-13,10$ & $-1,61$ & 11,03 & 30,77 & 3,16 & 7,75 & 6,33 \\
\hline & 300 & $-4,19$ & 5,21 & 19,14 & 51,70 & 5,23 & 7,03 & 14,02 \\
\hline \multirow{3}{*}{$\mathrm{F}$} & 97 & 13,01 & 9,02 & 16,52 & 29,08 & 4,73 & 12,57 & 14,15 \\
\hline & 198 & 3,00 & 11,85 & 31,10 & 17,99 & 18,44 & 21,19 & 17,26 \\
\hline & 300 & 16,44 & 15,23 & 47,91 & 26,59 & 30,22 & 36,69 & 28,85 \\
\hline \multirow{3}{*}{ G } & 97 & $-7,71$ & $-9,68$ & $-6,51$ & $-9,82$ & $-7,65$ & $-6,40$ & $-7,96$ \\
\hline & 198 & $-10,54$ & $-13,01$ & $-11,11$ & $-10,01$ & $-9,95$ & $-9,89$ & $-10,75$ \\
\hline & 300 & $-5,91$ & $-12,82$ & $-7,93$ & $-8,18$ & $-2,12$ & $-2,85$ & $-6,64$ \\
\hline \multirow{3}{*}{$\mathrm{H}$} & 97 & 9,34 & 28,72 & 9,42 & 17,69 & 19,63 & 18,87 & 17,28 \\
\hline & 198 & $-5,39$ & 12,95 & 15,81 & 6,69 & $-11,24$ & 9,44 & 4,71 \\
\hline & 300 & $-9,67$ & 15,96 & 38,79 & $-1,49$ & $-7,34$ & 16,58 & 8,81 \\
\hline \multirow{3}{*}{1} & 97 & $-13,52$ & $-4,03$ & $-3,79$ & $-12,30$ & $-8,54$ & $-12,54$ & $-9,12$ \\
\hline & 198 & $-17,70$ & $-15,75$ & $-17,65$ & $-20,08$ & $-20,70$ & $-20,87$ & $-18,79$ \\
\hline & 300 & $-13,99$ & $-13,28$ & $-12,57$ & $-13,95$ & $-14,05$ & $-10,45$ & $-13,05$ \\
\hline \multirow{3}{*}{$\mathrm{J}$} & 97 & $-8,23$ & $-1,99$ & $-5,39$ & $-9,40$ & $-5,29$ & $-7,16$ & $-6,24$ \\
\hline & 198 & $-15,86$ & $-11,36$ & $-14,56$ & $-13,28$ & $-12,21$ & $-16,91$ & $-14,03$ \\
\hline & 300 & $-13,43$ & $-11,08$ & $-6,91$ & $-12,75$ & $-6,55$ & $-12,23$ & $-10,49$ \\
\hline \multirow{3}{*}{$\mathrm{K}$} & 97 & $-4,56$ & 15,37 & 14,52 & $-5,26$ & 25,15 & 14,67 & 9,98 \\
\hline & 198 & $-3,20$ & 14,21 & $-0,39$ & $-12,06$ & 2,40 & 11,81 & 2,13 \\
\hline & 300 & 4,92 & 20,87 & $-2,39$ & $-3,31$ & 17,86 & 31,69 & 11,61 \\
\hline \multirow{3}{*}{ L } & 97 & $-15,79$ & $-3,92$ & $-1,13$ & $-9,97$ & $-5,23$ & $-3,66$ & $-6,62$ \\
\hline & 198 & $-7,32$ & $-4,24$ & $-2,54$ & $-14,52$ & $-3,17$ & $-14,73$ & $-7,75$ \\
\hline & 300 & 0,36 & $-2,02$ & 8,04 & $-9,97$ & $-1,64$ & $-4,86$ & $-1,68$ \\
\hline \multirow{3}{*}{$M$} & 97 & $-8,86$ & $-9,50$ & $-9,77$ & $-12,13$ & $-4,52$ & $-2,14$ & $-7,82$ \\
\hline & 198 & $-18,26$ & $-5,85$ & $-22,00$ & $-11,93$ & $-19,40$ & $-7,44$ & $-14,15$ \\
\hline & 300 & $-4,41$ & $-1,12$ & $-4,59$ & $-10,70$ & $-1,49$ & 3,21 & $-3,18$ \\
\hline \multirow{3}{*}{$\mathrm{N}$} & 97 & $-2,08$ & $-5,54$ & 16,29 & $-5,27$ & $-4,48$ & $-2,81$ & $-0,65$ \\
\hline & 198 & $-8,75$ & $-11,22$ & $-7,03$ & $-10,11$ & $-10,17$ & $-10,55$ & $-9,64$ \\
\hline & 300 & $-0,12$ & $-5,93$ & $-5,67$ & $-5,46$ & $-5,29$ & $-3,00$ & $-4,24$ \\
\hline \multirow{3}{*}{$\mathrm{O}$} & 97 & $-4,16$ & $-2,54$ & $-1,68$ & $-15,22$ & $-8,78$ & $-7,17$ & $-6,59$ \\
\hline & 198 & $-7,08$ & $-3,89$ & $-12,98$ & $-15,63$ & $-21,97$ & $-15,60$ & $-12,86$ \\
\hline & 300 & $-9,79$ & $-5,76$ & $-8,11$ & $-15,62$ & $-16,81$ & $-16,80$ & $-12,15$ \\
\hline
\end{tabular}


Anexo B - Graus de entupimento dos modelos de gotejadores testados, obtidos a partir da avaliação de vazão completa a 373 horas, depois da aplicação de água residuária realizada na segunda etapa

\begin{tabular}{|c|c|c|c|c|c|c|c|c|c|c|c|c|c|c|c|}
\hline \multirow{2}{*}{$\begin{array}{l}\text { Tosiçaa do } \\
\text { gotejador }\end{array}$} & \\
\hline & A & B & $\mathrm{C}$ & $\mathrm{D}$ & $E$ & $F$ & G & $\mathrm{H}$ & 1 & $\mathrm{~J}$ & K & $L$ & $\mathrm{M}$ & $\mathrm{N}$ & $\mathrm{O}$ \\
\hline & 19.05 & -3.23 & 10.27 & -2.88 & 23.60 & 19.59 & -2.34 & 3.47 & -11.54 & -11.31 & -4.86 & -1.06 & -7.04 & 21.14 & -2.01 \\
\hline 2 & 15.73 & -6.04 & 7.38 & -2.24 & 1.37 & 15.82 & -7.31 & -3.65 & -4.17 & -8.79 & 9.28 & -7.35 & 18.77 & -5333 & -8.90 \\
\hline 3 & 10.53 & -2.69 & 6.77 & 0.56 & 8.91 & 24.33 & -6.90 & 11.49 & -7.71 & -11.57 & $\begin{array}{l}-1.43 \\
-\end{array}$ & 9.17 & 37.32 & -8.18 & -12.86 \\
\hline 4 & $\begin{array}{l}18.53 \\
18.21\end{array}$ & $\begin{array}{l}-2.09 \\
-4.79\end{array}$ & 4.43 & $\begin{array}{l}6.50 \\
6.51\end{array}$ & $\begin{array}{l}0.91 \\
-0.78\end{array}$ & $\begin{array}{l}24.35 \\
29.29\end{array}$ & $\begin{array}{l}-0.90 \\
-2.28\end{array}$ & $\begin{array}{l}1.49 \\
-3.36\end{array}$ & -4.47 & $\begin{array}{l}-11.51 \\
-9.31\end{array}$ & $\begin{array}{l}-1.43 \\
21.62\end{array}$ & 10.70 & $\begin{array}{l}17.32 \\
12.59\end{array}$ & $\begin{array}{l}-0.10 \\
-6.21\end{array}$ & $\begin{array}{l}-1.080 \\
-3.49\end{array}$ \\
\hline 5 & 19.24 & -2.52 & 7.84 & -12.13 & 10.43 & 69.31 & -8.18 & 10.68 & -7.38 & -6.69 & 7.05 & 10.62 & 12.93 & -2.83 & -13.22 \\
\hline 6 & 28.83 & -4.69 & 9.72 & 55.46 & 10.65 & 12.46 & -1.70 & 12.59 & 3.03 & 36.05 & 7.20 & 13.35 & 39.67 & -2.11 & -16.08 \\
\hline 7 & 9.31 & $\begin{array}{l}-3.66 \\
\end{array}$ & 6.08 & $\begin{array}{l}27.40 \\
27.19\end{array}$ & 54.01 & 25.62 & 3.28 & $\begin{array}{l}-3.16 \\
\end{array}$ & 27.24 & -9.76 & 13.58 & 9.29 & 31.49 & -10.07 & -7.43 \\
\hline 8 & 5.89 & -1.44 & 7.80 & 20.89 & 31.22 & 40.18 & 1.60 & 25.41 & 1.07 & -12.26 & 3.22 & 17.51 & -1.34 & -7.90 & $\begin{array}{l}-1.40 \\
-9.97\end{array}$ \\
\hline 9 & 22.84 & -9.53 & 7.29 & 25.34 & -5.35 & 48.01 & -3.81 & 9.23 & -3.74 & -9.94 & 38.62 & 37.66 & 49.54 & -0.88 & -16.98 \\
\hline 10 & 11.97 & -0.91 & 14.03 & 4.86 & -3.74 & 25.00 & -1.30 & 0.91 & -3.28 & -14.37 & 62.69 & -7.36 & -2.73 & -2.78 & -17.97 \\
\hline 11 & 21.13 & 0.22 & 1.31 & -2.80 & 5.52 & 18.72 & -8.30 & -0.13 & -6.80 & -12.92 & 42.77 & 5.08 & 23.10 & 19.30 & 40.75 \\
\hline 12 & 21.87 & $\begin{array}{l}-3.62 \\
\end{array}$ & 3.29 & -2.25 & 6.72 & 41.35 & -1.96 & 12.75 & 1.34 & -15.68 & 28.27 & -1.33 & 7.20 & -6.99 & -18.34 \\
\hline 13 & 16.43 & -4.41 & 6.95 & -6.37 & 4.96 & 15.77 & -9.01 & -1.65 & -11.70 & -10.44 & 28.02 & -1.30 & 32.59 & -8.89 & -15.80 \\
\hline 14 & 8.11 & -5.12 & 7.68 & -7.14 & 18.56 & 42.90 & $\begin{array}{l}-2.32 \\
-\end{array}$ & 27.62 & -11.38 & -11.77 & 33.15 & 3.86 & -1.03 & -6.52 & -13.80 \\
\hline 15 & 14.81 & -4.83 & 4.54 & 11.36 & 48.10 & 25.62 & -4.29 & 0.07 & -7.64 & -9.72 & 56.43 & 7.46 & 38.38 & -10.25 & $\begin{array}{l}-14.66 \\
\end{array}$ \\
\hline 16 & $\begin{array}{l}74.01 \\
12.69\end{array}$ & $\begin{array}{l}-4.05 \\
-2.24\end{array}$ & $\begin{array}{l}4.54 \\
15.39\end{array}$ & $\begin{array}{l}1.00 \\
-4.89\end{array}$ & $\begin{array}{l}5.70 \\
5.70\end{array}$ & $\begin{array}{l}19.76 \\
\end{array}$ & 3.40 & 8.64 & $\begin{array}{l}-1.04 \\
-8.71\end{array}$ & $\begin{array}{l}-9.12 \\
-4.35\end{array}$ & $\begin{array}{l}40.40 \\
45.02\end{array}$ & $\begin{array}{l}1.40 \\
13.42\end{array}$ & $\begin{array}{l}50.00 \\
31.12\end{array}$ & $\begin{array}{l}-6.40 \\
-6.41\end{array}$ & $\begin{array}{l}-12.00 \\
-12.49\end{array}$ \\
\hline 17 & $\begin{array}{l}12.09 \\
15.86\end{array}$ & $\begin{array}{l}-2.24 \\
-5.41\end{array}$ & 8.02 & $\begin{array}{l}-8.09 \\
9.74\end{array}$ & $\begin{array}{l}.10 \\
40.83\end{array}$ & 45.20 & $\begin{array}{l}.40 \\
4.99\end{array}$ & $\begin{array}{c}0.04 \\
-12.26\end{array}$ & $\begin{array}{l}-8.11 \\
-3.64\end{array}$ & $\begin{array}{l}-4.35 \\
53.68\end{array}$ & $\begin{array}{l}41.02 \\
21.30\end{array}$ & $\begin{array}{l}3.42 \\
9.75\end{array}$ & $\begin{array}{l}20.92 \\
20.92\end{array}$ & $\begin{array}{l}-0.41 \\
-9.21\end{array}$ & $\begin{array}{l}-11.49 \\
-16.00\end{array}$ \\
\hline 18 & 25.92 & -3.15 & 8.16 & 16.32 & 26.83 & 12.37 & 0.63 & 4.17 & -10.78 & -5.30 & 47.35 & 0.87 & 23.16 & 0.30 & -20.04 \\
\hline $\begin{array}{l}18 \\
19\end{array}$ & 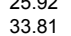 & $\begin{array}{l}-3.15 \\
-2.15\end{array}$ & $\begin{array}{l}8.16 \\
29.52\end{array}$ & $\begin{array}{l}16.32 \\
15.27\end{array}$ & $\begin{array}{l}26.83 \\
18.38\end{array}$ & $\begin{array}{l}72.31 \\
28.82\end{array}$ & $\begin{array}{r}.63 \\
-6.09\end{array}$ & $\begin{array}{l}4.11 \\
3.22\end{array}$ & $\begin{array}{c}-10.188 \\
0.03\end{array}$ & $\begin{array}{l}-5.30 \\
-8.32\end{array}$ & $\begin{array}{l}47.35 \\
19.08\end{array}$ & $\begin{array}{l}0.87 \\
5.23\end{array}$ & $\begin{array}{c}23.16 \\
4.85\end{array}$ & $\begin{array}{r}.30 \\
-12.76\end{array}$ & $\begin{array}{l}-20.04 \\
-13.27\end{array}$ \\
\hline 20 & 22.46 & -2.96 & 18.59 & 4.94 & 6.60 & 59.53 & -4.52 & 5.46 & 11.17 & -4.58 & 26.51 & 12.02 & 11.12 & $\begin{array}{l}-14.16 \\
\end{array}$ & -18.51 \\
\hline 21 & 12.82 & -3.27 & 8.87 & -4.92 & 13.64 & 44.55 & -2.06 & 26.37 & -5.18 & 7.43 & 21.24 & 14.41 & 16.90 & -5.87 & -11.45 \\
\hline 22 & $\begin{array}{l}16.02 \\
16.22\end{array}$ & -5.04 & $\begin{array}{l}15.01 \\
15.81\end{array}$ & -6.44 & 48.25 & 33.79 & -4.43 & 22.46 & -9.21 & $\begin{array}{l}1.40 \\
-10.94\end{array}$ & $\begin{array}{l}-3.19 \\
-3.19\end{array}$ & 2.01 & $\begin{array}{l}41.13 \\
4\end{array}$ & $\begin{array}{l}-8.07 \\
-8.49\end{array}$ & $\begin{array}{l}-10.64 \\
-\end{array}$ \\
\hline 23 & 21.30 & -5.74 & 21.67 & -1.98 & 67.33 & 42.64 & -5.65 & 12.66 & 0.67 & -13.32 & 1.53 & 4.43 & 4.18 & -0.98 & -2.05 \\
\hline 24 & 10.81 & 33.47 & 14.07 & 14.65 & 62.49 & 20.20 & 2.56 & 26.97 & 4.54 & -6.48 & 14.64 & -11.43 & 85.52 & -7.51 & -11.48 \\
\hline 25 & 19.69 & -0.20 & 32.10 & 12.62 & 55.79 & 42.40 & 4.81 & 17.94 & -15.10 & -7.46 & 19.61 & -1.27 & 31.41 & -7.14 & -13.97 \\
\hline Linha 2 & & & & & & & & & & & & & & & \\
\hline 1 & 11.72 & 1.03 & 6.86 & 15.85 & 16.96 & 73.09 & -2.36 & -6.21 & -18.75 & -9.27 & 3.58 & -5.48 & -5.23 & -10.49 & -8.42 \\
\hline 2 & 18.72 & -3.26 & 5.75 & -5.13 & 2.43 & 4.40 & -7.65 & -0.66 & -4.82 & -2.97 & $\begin{array}{l}-2.81 \\
-2.81\end{array}$ & 12.29 & -9.30 & -3.81 & $\begin{array}{l}-10.29 \\
\end{array}$ \\
\hline 3 & 10.73 & $\begin{array}{r}-0.20 \\
-12.16\end{array}$ & 4.25 & -4.14 & 65.16 & 22.26 & 5.28 & -2.71 & -9.22 & -14.00 & -1.49 & -4.41 & -16.77 & 1.79 & -11.82 \\
\hline 4 & $\begin{array}{l}6.10 \\
6.62\end{array}$ & -5.65 & $\begin{array}{l}15.75 \\
15.77\end{array}$ & $\begin{array}{l}-4.14 \\
-4.78\end{array}$ & $\begin{array}{l}57.17 \\
57.17\end{array}$ & 12.54 & $\begin{array}{l}.20 \\
-6.68\end{array}$ & 4.18 & $\begin{array}{l}-9.28 \\
-9.00\end{array}$ & $\begin{array}{l}-14.100 \\
-\end{array}$ & $\begin{array}{l}-1.49 \\
-2.84\end{array}$ & $\begin{array}{l}-4.41 \\
-3.69\end{array}$ & -8.79 & 9.94 & $\begin{array}{l}-1.120 \\
-12.98\end{array}$ \\
\hline $\begin{array}{l}4 \\
5\end{array}$ & $\begin{array}{l}\text {.0.02 } \\
7.46\end{array}$ & $\begin{array}{l}-0.05 \\
-8.85\end{array}$ & 4.51 & $\begin{array}{l}-4.18 \\
-6.84\end{array}$ & 6.59 & $\begin{array}{r}2 . .54 \\
35.72\end{array}$ & $\begin{array}{l}-0.00 \\
-3.18\end{array}$ & $\begin{array}{r}4.18 \\
-2.25\end{array}$ & $\begin{array}{l}-11.00 \\
-11.30\end{array}$ & $\begin{array}{l}-11.110 \\
-11.44\end{array}$ & $\begin{array}{l}-2.04 \\
-2.95\end{array}$ & $\begin{array}{l}-3.09 \\
-8.82\end{array}$ & $\begin{array}{l}-61.19 \\
-11.07\end{array}$ & $\begin{array}{r}-3.94 \\
-3.56\end{array}$ & $\begin{array}{l}-12.98 \\
-20.53\end{array}$ \\
\hline $\begin{array}{l}5 \\
6\end{array}$ & $\begin{array}{r}.40 \\
4.89\end{array}$ & $\begin{array}{l}-0.05 \\
7.85\end{array}$ & $\begin{array}{l}.451 \\
12.18\end{array}$ & $\begin{array}{l}-0.64 \\
-12.63\end{array}$ & $\begin{array}{l}\text {.59 } \\
2.09\end{array}$ & $\begin{array}{l}3.12 \\
12.22\end{array}$ & $\begin{array}{l}-3.10 \\
-11.98\end{array}$ & $\begin{array}{l}-2.20 \\
30.58\end{array}$ & -10.06 & $\begin{array}{l}-1.144 \\
-7.30\end{array}$ & 3.22 & $\begin{array}{l}-8.02 \\
-8.00\end{array}$ & -4.61 & $\begin{array}{l}-3.50 \\
-1.95\end{array}$ & $\begin{array}{l}-2.035 \\
-15.72\end{array}$ \\
\hline $\begin{array}{l}6 \\
7\end{array}$ & $\begin{array}{l}4.89 \\
9.16\end{array}$ & $\begin{array}{l}-.85 \\
-7.61\end{array}$ & $\begin{array}{l}12.18 \\
4.81\end{array}$ & $\begin{array}{l}-1.03 \\
-9.25\end{array}$ & $\begin{array}{l}2.09 \\
10.78\end{array}$ & $\begin{array}{l}12.22 \\
50.75\end{array}$ & $\begin{array}{c}-11.18 \\
5.49\end{array}$ & $\begin{array}{l}30.58 \\
13.39\end{array}$ & $\begin{array}{l}-10.06 \\
-9.32\end{array}$ & $\begin{array}{l}-7.30 \\
1.24\end{array}$ & $\begin{array}{l}3.22 \\
7.20\end{array}$ & $\begin{array}{l}-8.00 \\
-3.93\end{array}$ & $\begin{array}{l}-4.61 \\
14.99\end{array}$ & $\begin{array}{l}-1.95 \\
-8.36\end{array}$ & $\begin{array}{l}-15 . / 2 \\
-15.00\end{array}$ \\
\hline 8 & 12.82 & -5.05 & 3.47 & $\begin{array}{l}-2.89 \\
-\end{array}$ & 27.31 & 24.41 & $\begin{array}{l}-6.40 \\
-6.86\end{array}$ & 16.13 & 4.08 & $\begin{array}{l}1.249 \\
-12.99\end{array}$ & 0.53 & -7.15 & -2.37 & -2.96 & $\begin{array}{l}-14.05 \\
\end{array}$ \\
\hline 9 & 14.00 & -11.95 & 9.10 & -6.26 & 25.61 & 14.73 & $\begin{array}{l}-7.91 \\
\end{array}$ & 12.57 & -12.64 & $\begin{array}{l}-14.97 \\
\end{array}$ & 54.73 & 8.28 & -1.15 & -0.04 & $\begin{array}{l}-13.86 \\
\end{array}$ \\
\hline 10 & 8.31 & -4.60 & 4.11 & -8.41 & 1.11 & 23.03 & -1.29 & 6.43 & -6.21 & $\begin{array}{l}-10.34 \\
-\end{array}$ & 10.92 & $\begin{array}{l}3.20 \\
3.61\end{array}$ & -5.04 & $\begin{array}{l}-0.04 \\
-6.01\end{array}$ & $\begin{array}{l}-18.000 \\
-18.90\end{array}$ \\
\hline 11 & 10.47 & -11.31 & 10.02 & -8.21 & 22.97 & 18.08 & -2.41 & 4.58 & -10.11 & -13.91 & 25.88 & 6.34 & -9.84 & -2.42 & -13.97 \\
\hline 12 & 6.22 & -3.60 & 13.35 & 2.41 & 5.03 & 27.08 & -8.10 & 8.35 & -10.38 & -8.68 & 11.68 & 27.73 & -1.97 & -1.91 & -14.39 \\
\hline 13 & 7.26 & -10.25 & 3.67 & 4.13 & 4.97 & 34.68 & -2.98 & -5.62 & -14.28 & -9.98 & 22.44 & 3.85 & 8.80 & -1.42 & -10.65 \\
\hline 14 & 7.40 & -10.72 & 7.27 & -6.13 & 0.79 & 16.39 & -3.41 & 2.14 & -11.21 & -8.07 & 2.25 & -0.13 & 6.88 & -0.23 & -24.69 \\
\hline 15 & 14.23 & -11.98 & 10.69 & -6.32 & 6.92 & 24.89 & -5.91 & 15.55 & -8.79 & -14.80 & 16.67 & 1.73 & 16.01 & -6.37 & -19.87 \\
\hline 16 & 25.28 & $\begin{array}{l}-9.60 \\
-9.64\end{array}$ & 10.03 & -2.06 & $\begin{array}{l}-2.85 \\
-\end{array}$ & $\begin{array}{l}18.05 \\
13.13\end{array}$ & 2.42 & $\begin{array}{l}37.40 \\
37\end{array}$ & -11.20 & -9.29 & $\begin{array}{l}-3.63 \\
\end{array}$ & $\begin{array}{l}1.10 \\
-3.19\end{array}$ & -7.34 & -2.71 & $\begin{array}{l}-10.31 \\
-10.33\end{array}$ \\
\hline 17 & 8.70 & $\begin{array}{l}-3.04 \\
-6.53\end{array}$ & 8.03 & 1.25 & 3.38 & 10.26 & $\begin{array}{l}-2.42 \\
-8.46\end{array}$ & 22.96 & -5.77 & $\begin{array}{l}-5.29 \\
-11.90\end{array}$ & $\begin{array}{l}-0.00 \\
-2.72\end{array}$ & 9.95 & 4.01 & -0.98 & -20.31 \\
\hline 18 & $\begin{array}{l}0.10 \\
11.85\end{array}$ & $\begin{array}{l}-0.03 \\
-7.32\end{array}$ & 9.58 & $\begin{array}{l}4.34 \\
4.34\end{array}$ & $\begin{array}{l}5.00 \\
3.65\end{array}$ & 17.41 & $\begin{array}{l}-0.40 \\
-10.39\end{array}$ & $\begin{array}{l}12.30 \\
12.38\end{array}$ & -7.11 & -6.06 & $\begin{array}{l}12.82 \\
12.82\end{array}$ & $\begin{array}{r}\text { r.90 } \\
-5.99\end{array}$ & 5.87 & 8.33 & -21.89 \\
\hline $\begin{array}{l}18 \\
19\end{array}$ & 9.21 & $\begin{array}{l}-1.32 \\
-12.86\end{array}$ & $\begin{array}{l}9.00 \\
8.72\end{array}$ & $\begin{array}{l}4.34 \\
8.93\end{array}$ & $\begin{array}{l}5.00 \\
5.46\end{array}$ & 21.55 & $\begin{array}{l}-9.439 \\
-9.49\end{array}$ & $\begin{array}{l}12.38 \\
16.60\end{array}$ & -5.52 & $\begin{array}{l}-0.00 \\
-11.33\end{array}$ & $\begin{array}{l}-0.02 \\
-0.14\end{array}$ & 8.88 & $\begin{array}{l}\text {.07 } \\
11.27\end{array}$ & $\begin{array}{l}0.35 \\
-2.27\end{array}$ & $\begin{array}{l}-19.08 \\
-19.04\end{array}$ \\
\hline 20 & $\begin{array}{l}. .21 \\
16.91\end{array}$ & $\begin{array}{l}-12.80 \\
-3.18\end{array}$ & $\begin{array}{l}0.12 \\
5.99\end{array}$ & $\begin{array}{l}-4.93 \\
-4.98\end{array}$ & $\begin{array}{l}\text {. } 12.40 \\
12.55\end{array}$ & $\begin{array}{l}1.50 \\
18.08\end{array}$ & $\begin{array}{l}-9.49 \\
-10.26\end{array}$ & $\begin{array}{l}10.00 \\
36.00\end{array}$ & $\begin{array}{l}-5.52 \\
-10.00\end{array}$ & $\begin{array}{l}-1.135 \\
-15.59\end{array}$ & $\begin{array}{l}-0.14 \\
43.11\end{array}$ & $\begin{array}{l}4.80 \\
4.62\end{array}$ & $\begin{array}{l}11.27 \\
16.14\end{array}$ & -7.85 & $\begin{array}{l}-17.044 \\
-17.90\end{array}$ \\
\hline 21 & 15.79 & - 15.43 & 6.29 & -0.85 & 13.51 & 35 & -1.67 & 13.26 & -6.28 & -9.14 & 23. & -5. & 2.31 & -4.90 & -19.82 \\
\hline 22 & 11.63 & 6.69 & $\begin{array}{l}13.41 \\
\text { S }\end{array}$ & 5.65 & 67.4 & 48. & -7.1 & 19.95 & 0.66 & -9.3 & 22. & 10. & -3.74 & $\begin{array}{l}-10.67 \\
\end{array}$ & $\begin{array}{l}-26.23 \\
\end{array}$ \\
\hline 23 & 11. & -6.3 & 7.32 & $\begin{array}{l}-14.02 \\
-0.03\end{array}$ & 63. & 32. & 2.2 & 4.6 & -6.9 & -14. & 35. & 22.03 & 18.8 & -8 & -21.33 \\
\hline 24 & 17.84 & -9.17 & 17.68 & -4.36 & 50.53 & 24. & -0.32 & 1.28 & -10.31 & -7. & 9.67 & 9.85 & -1.75 & -6.50 & -21.20 \\
\hline 25 & 46.81 & 2.20 & 18.91 & -2.46 & 7.80 & 52.69 & 11.15 & 29.11 & -11.65 & -8.67 & 1.74 & 7.71 & -7.48 & -3.34 & -14.18 \\
\hline média & 15.23 & -4.27 & 9.99 & 2.09 & 20.82 & 29.54 & -3.06 & 10.16 & -5.99 & -7.46 & 17.01 & 4.74 & 11.41 & -3.75 & -13.56 \\
\hline
\end{tabular}




\begin{abstract}
Anexo C - Resultado gráfico da análise de probabilidades de encontrar valores de vazão na faixa de $\pm 5 \%$ de variação em relação à vazão dos emssores quando novos, depois de 373 horas de aplicação de água residuária em diferentes modelos de gotejadores utilizados
\end{abstract}

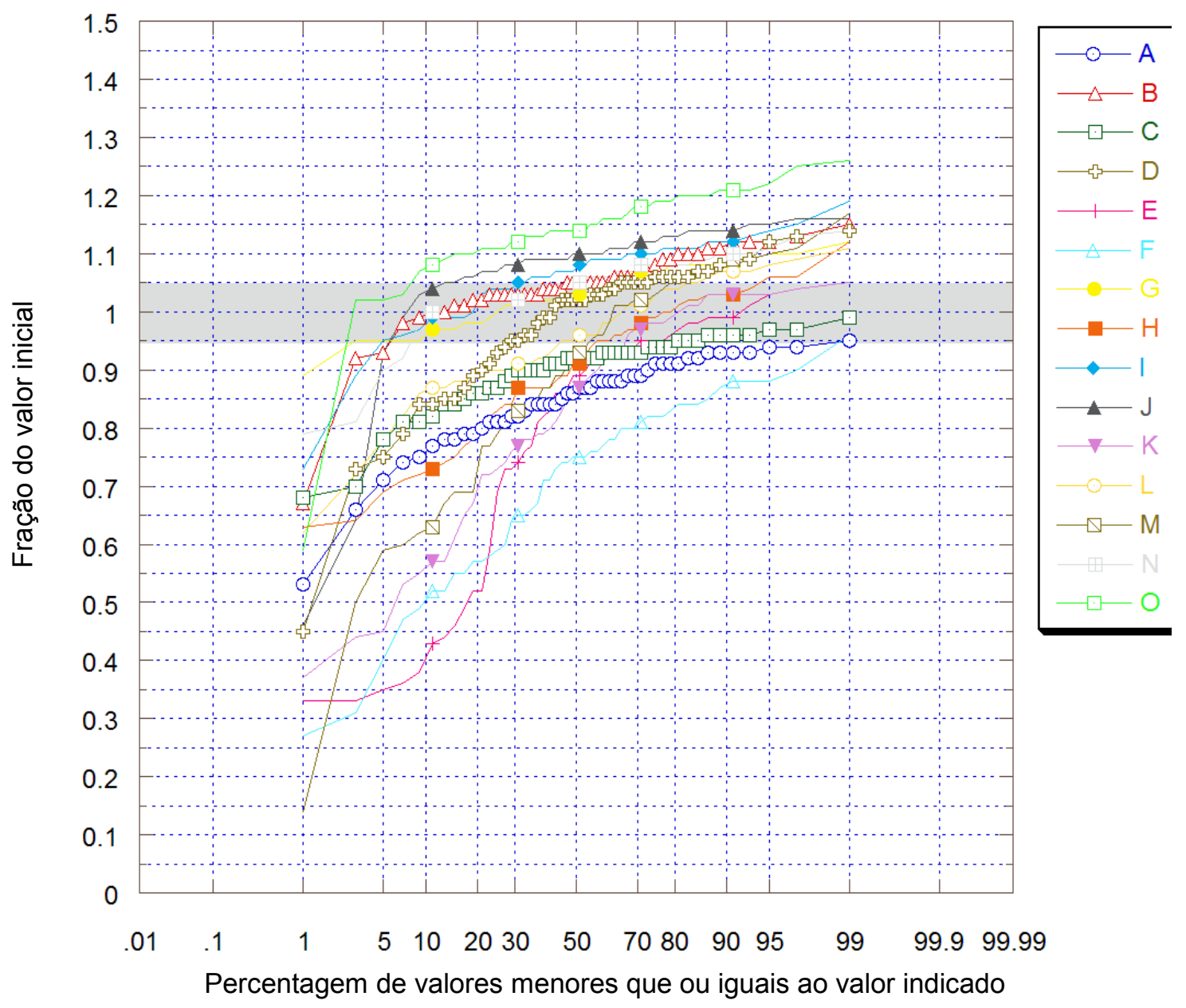


Anexo D - Graus de entupimento do modelo M no tratamento controle, obtidos a partir de avaliações de amostrais e completas de vazão, depois da aplicação de água residuária realizada na terceira etapa

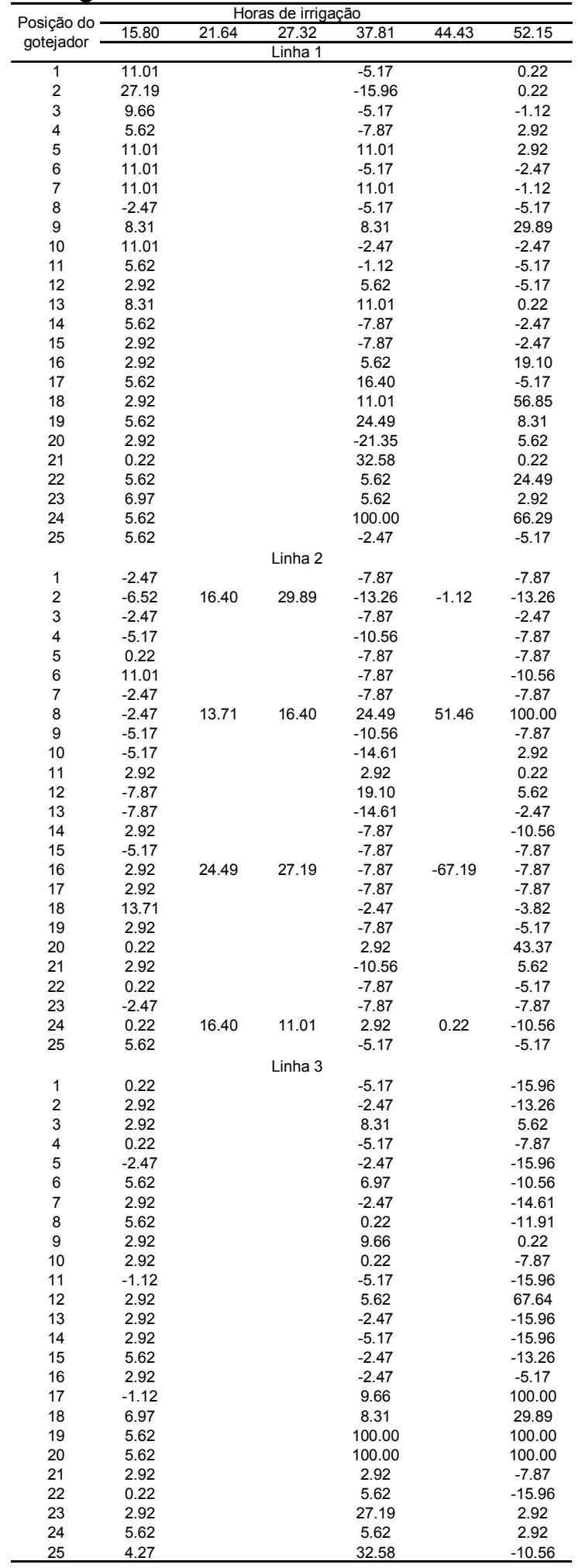


Anexo E - Graus de entupimento do modelo E no tratamento controle, obtidos a partir de avaliações de amostrais e completas de vazão, depois da aplicação de água residuária realizada na terceira etapa

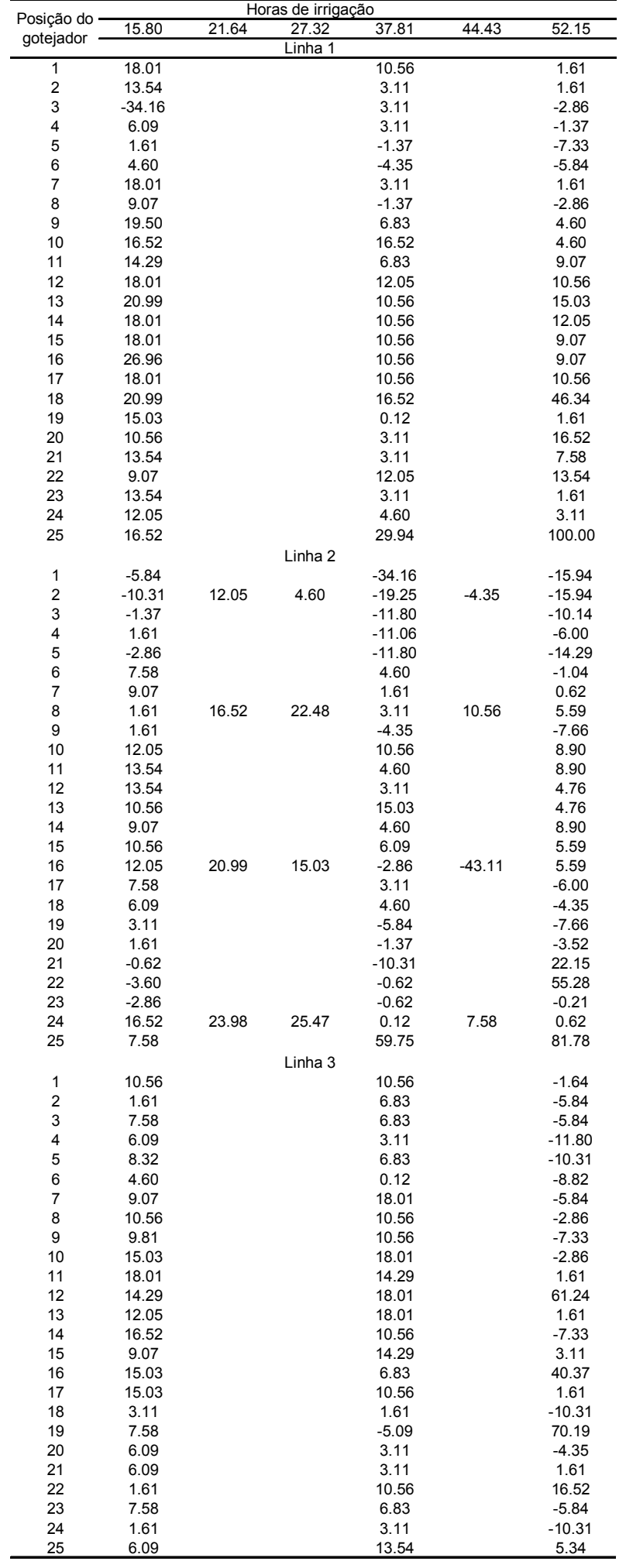


Anexo F - Graus de entupimento do modelo D no tratamento controle, obtidos a partir de avaliações de amostrais e completas de vazão, depois da aplicação de água residuária realizada na terceira etapa

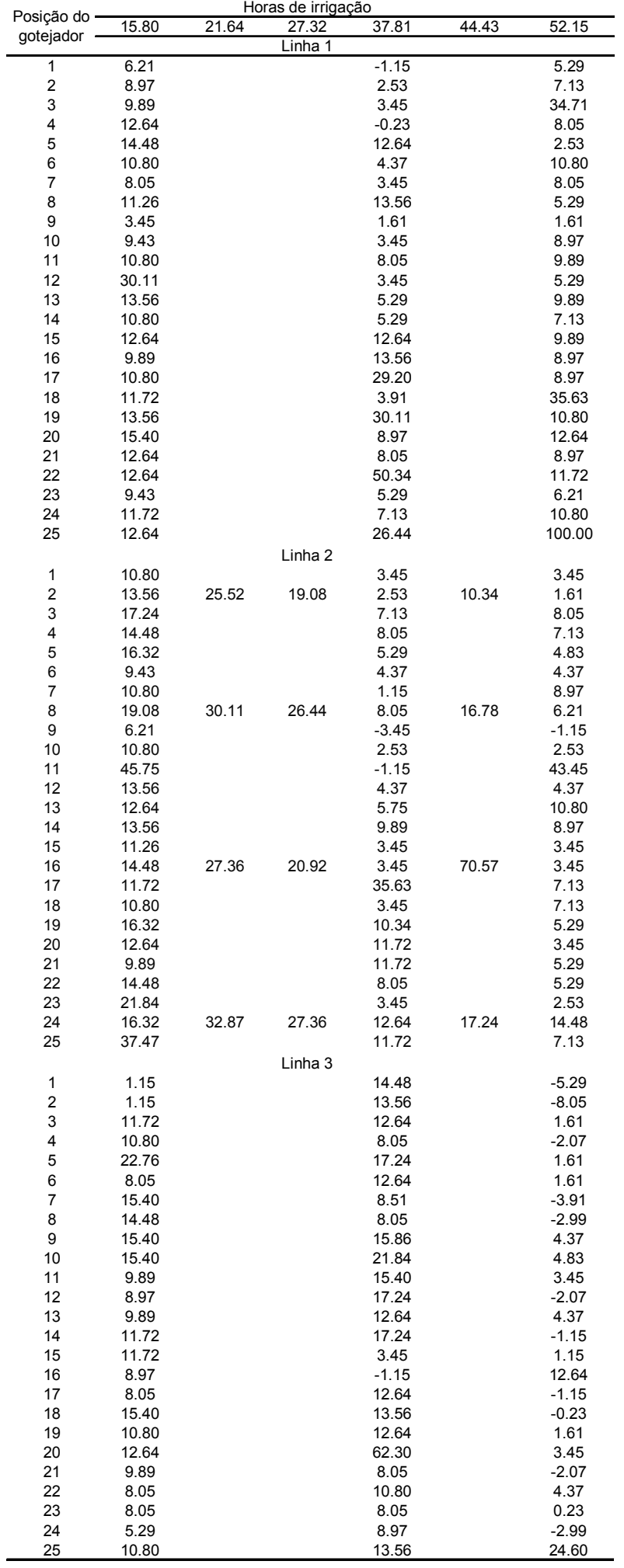


Anexo G - Graus de entupimento do modelo B no tratamento controle, obtidos a partir de avaliações de amostrais e completas de vazão, depois da aplicação de água residuária realizada na terceira etapa

\begin{tabular}{|c|c|c|c|c|c|c|}
\hline \multirow{3}{*}{$\begin{array}{l}\text { Posição do } \\
\text { gotejador }\end{array}$} & \multicolumn{5}{|c|}{ as de irriga } & \multirow{3}{*}{52.15} \\
\hline & 15.80 & 21.64 & 27.32 & 37.81 & 44.43 & \\
\hline & \multicolumn{5}{|c|}{ Linha 1} & \\
\hline 1 & 3.41 & & & 23.17 & & 7.80 \\
\hline 2 & 4.88 & & & -2.44 & & 4.88 \\
\hline 3 & 3.41 & & & 63.41 & & -2.44 \\
\hline 4 & 0.49 & & & 26.83 & & -9.76 \\
\hline 5 & 0.49 & & & -6.10 & & -5.37 \\
\hline 6 & 4.15 & & & -2.44 & & -0.98 \\
\hline 7 & 4.88 & & & -5.37 & & -2.44 \\
\hline 8 & 1.95 & & & -0.98 & & 3.41 \\
\hline 9 & 3.41 & & & -6.10 & & -6.83 \\
\hline 10 & 6.34 & & & -2.44 & & -8.29 \\
\hline 11 & 3.41 & & & -3.17 & & 4.88 \\
\hline 12 & -0.98 & & & -6.83 & & -8.29 \\
\hline 13 & 4.88 & & & 0.49 & & -9.76 \\
\hline 14 & 1.95 & & & -2.44 & & -0.98 \\
\hline 15 & 4.88 & & & 19.51 & & -2.44 \\
\hline 16 & 10.73 & & & -2.44 & & -3.90 \\
\hline 17 & 2.68 & & & 8.54 & & -3.17 \\
\hline 18 & 3.41 & & & -9.76 & & -2.44 \\
\hline 19 & 1.95 & & & 3.41 & & -9.76 \\
\hline 20 & 2.68 & & & 20.98 & & -2.44 \\
\hline 21 & 16.59 & & & 22.44 & & 3.41 \\
\hline 22 & 3.41 & & & 4.88 & & 1.22 \\
\hline 23 & -9.76 & & & 18.05 & & -2.44 \\
\hline 24 & -0.98 & & & -3.90 & & -17.07 \\
\hline \multirow[t]{2}{*}{25} & 4.88 & & & 3.41 & & 0.49 \\
\hline & & & Linha 2 & & & \\
\hline 1 & -3.90 & & & -13.41 & & -9.76 \\
\hline 2 & -2.44 & -8.29 & -9.76 & -1.71 & -9.02 & -3.90 \\
\hline 3 & 16.59 & & & 1.22 & & 6.34 \\
\hline 4 & 3.41 & & & 4.15 & & -3.90 \\
\hline 5 & 6.34 & & & 15.12 & & -0.98 \\
\hline 6 & 4.88 & & & 6.34 & & -5.37 \\
\hline 7 & -2.44 & & & 20.98 & & -2.44 \\
\hline 8 & -3.90 & -6.83 & -5.37 & 6.34 & -9.76 & 0.49 \\
\hline 9 & 6.34 & & & 30.49 & & -5.37 \\
\hline 10 & 4.88 & & & 30.49 & & -5.37 \\
\hline 11 & 100.00 & & & 100.00 & & 100.00 \\
\hline 12 & -6.83 & & & -7.56 & & -5.37 \\
\hline 13 & 26.83 & & & -1.71 & & -3.90 \\
\hline 14 & 1.95 & & & 1.22 & & -9.76 \\
\hline 15 & -2.44 & & & -4.63 & & 3.41 \\
\hline 16 & -6.83 & -0.98 & 0.49 & 9.27 & -2.44 & 6.34 \\
\hline 17 & 3.41 & & & -6.10 & & -2.44 \\
\hline 18 & 6.34 & & & -9.02 & & -9.76 \\
\hline 19 & 7.80 & & & 9.27 & & 20.98 \\
\hline 20 & -14.15 & & & 1.22 & & -5.37 \\
\hline 21 & 1.95 & & & 100.00 & & 18.05 \\
\hline 22 & 4.88 & & & 6.34 & & 100.00 \\
\hline 23 & 3.41 & & & 6.34 & & 10.73 \\
\hline 24 & 3.41 & 92.68 & 100.00 & 86.10 & 100.00 & -2.44 \\
\hline \multirow[t]{2}{*}{25} & 10.73 & & 56.10 & 67.07 & 79.51 & 83.90 \\
\hline & & & Linha 3 & & & \\
\hline 1 & 0.49 & & & -0.98 & & 1.95 \\
\hline 2 & -5.37 & & & -9.76 & & -8.29 \\
\hline 3 & 7.80 & & & 12.20 & & 3.41 \\
\hline 4 & 0.49 & & & 19.51 & & -2.44 \\
\hline 5 & 1.95 & & & -0.98 & & -5.37 \\
\hline 6 & 0.49 & & & -5.37 & & 4.88 \\
\hline 7 & 4.88 & & & -8.29 & & -9.76 \\
\hline 8 & 1.22 & & & 1.22 & & -3.90 \\
\hline 9 & -5.37 & & & -11.22 & & -11.22 \\
\hline 10 & -2.44 & & & -3.90 & & -5.37 \\
\hline 11 & -0.98 & & & -2.44 & & -8.29 \\
\hline 12 & 6.34 & & & 4.88 & & -0.98 \\
\hline 13 & 9.27 & & & -2.44 & & -2.44 \\
\hline 14 & 3.41 & & & 9.27 & & -2.44 \\
\hline 15 & -8.29 & & & -3.90 & & -3.90 \\
\hline 16 & -0.24 & & & -2.44 & & -5.37 \\
\hline 17 & -8.29 & & & -2.44 & & -3.90 \\
\hline 18 & 7.80 & & & -6.83 & & -2.44 \\
\hline 19 & 6.34 & & & -12.68 & & -12.68 \\
\hline 20 & -22.93 & & & 9.27 & & -23.66 \\
\hline 21 & 6.34 & & & -11.22 & & -5.37 \\
\hline 22 & 6.34 & & & 1.95 & & -6.83 \\
\hline 23 & 1.95 & & & 3.41 & & -49.27 \\
\hline 24 & -8.29 & & & -3.90 & & 1.95 \\
\hline 25 & -0.98 & & & 0.49 & & 100.00 \\
\hline
\end{tabular}


Anexo H - Graus de entupimento do modelo M no tratamento com cloração, obtidos a partir de avaliações de amostrais e completas de vazão, depois da aplicação de água residuária realizada na terceira etapa

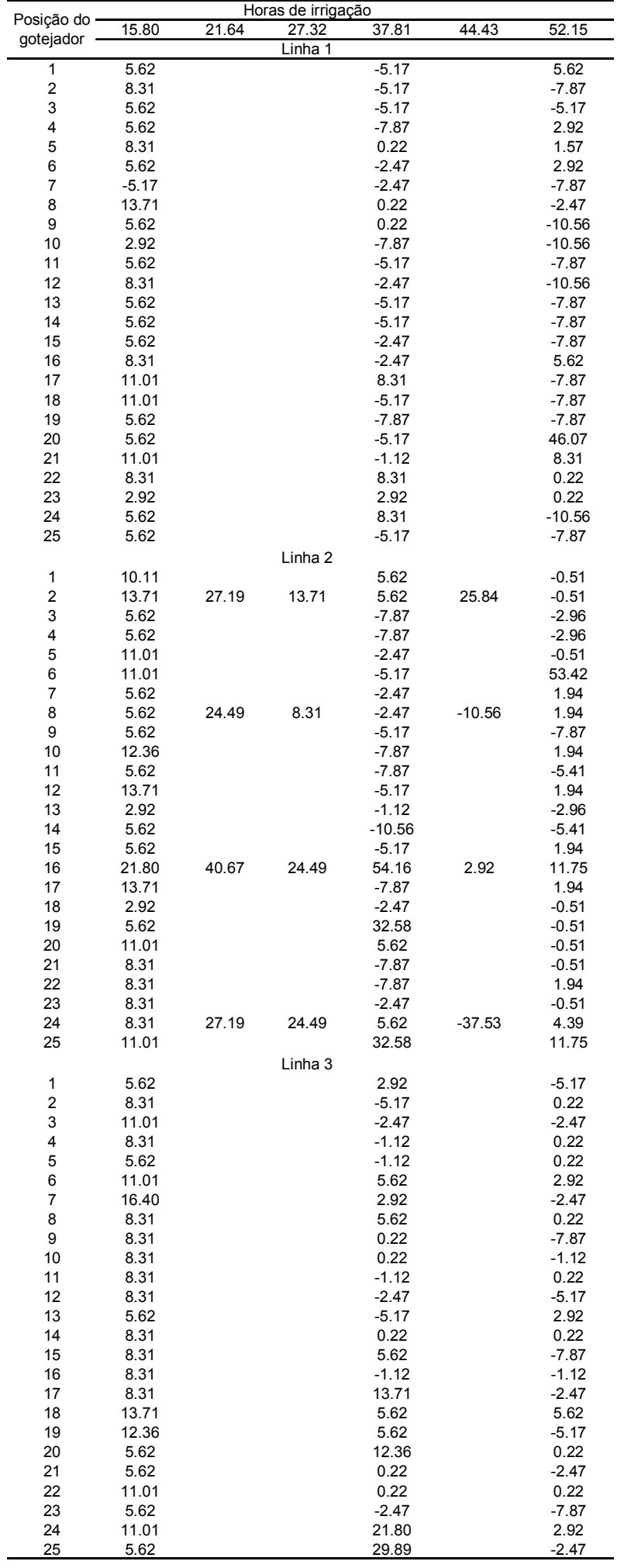


Anexo I - Graus de entupimento do modelo E no tratamento com cloração, obtidos a partir de avaliações de amostrais e completas de vazão, depois da aplicação de água residuária realizada na terceira etapa

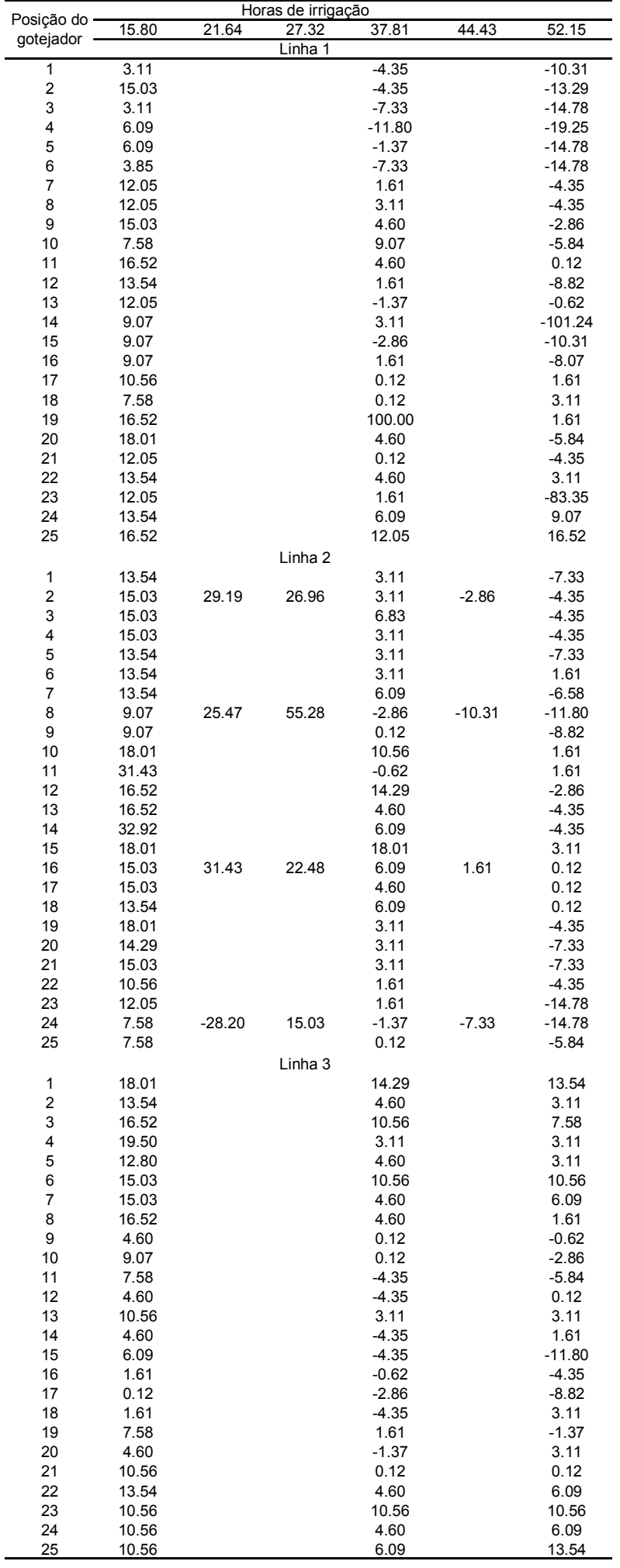


Anexo J - Graus de entupimento do modelo D no tratamento com cloração, obtidos a partir de avaliações de amostrais e completas de vazão, depois da aplicação de água residuária realizada na terceira etapa

\begin{tabular}{|c|c|c|c|c|c|c|}
\hline \multirow{3}{*}{$\begin{array}{l}\text { Posição do } \\
\text { gotejador }\end{array}$} & \multicolumn{5}{|c|}{ Horas de irrigação } & \multirow[b]{2}{*}{52.15} \\
\hline & 15.80 & 21.64 & 27.32 & 37.81 & 44.43 & \\
\hline & \multicolumn{5}{|c|}{ Linha 1} & \\
\hline 1 & 19.08 & & & 23.68 & & 19.08 \\
\hline 2 & 16.32 & & & 11.72 & & 5.29 \\
\hline 3 & 27.36 & & & 9.89 & & -2.99 \\
\hline 4 & 13.56 & & & 31.03 & & -5.75 \\
\hline 5 & 14.48 & & & -17.24 & & -0.23 \\
\hline 6 & 15.40 & & & 100.00 & & 3.91 \\
\hline 7 & 17.24 & & & 9.89 & & 3.45 \\
\hline 8 & 12.64 & & & 5.29 & & 12.64 \\
\hline 9 & 13.56 & & & 12.64 & & -1.15 \\
\hline 10 & 20.00 & & & 15.40 & & 2.53 \\
\hline 11 & 48.97 & & & 3.45 & & -2.07 \\
\hline 12 & 47.13 & & & 5.29 & & 13.56 \\
\hline 13 & 11.72 & & & 4.37 & & 40.23 \\
\hline 14 & 13.56 & & & 100.00 & & 2.53 \\
\hline 15 & 14.48 & & & 10.80 & & 22.76 \\
\hline 16 & 21.84 & & & 23.68 & & -5.75 \\
\hline 17 & 14.48 & & & 5.75 & & 13.56 \\
\hline 18 & 13.56 & & & 67.82 & & -1.15 \\
\hline 19 & 12.64 & & & 8.97 & & 20.00 \\
\hline 20 & 15.40 & & & 41.15 & & 3.45 \\
\hline 21 & 14.94 & & & 7.13 & & -0.23 \\
\hline 22 & 17.24 & & & 11.72 & & 19.08 \\
\hline 23 & 14.48 & & & 12.64 & & 0.69 \\
\hline 24 & 14.48 & & & 8.05 & & 0.69 \\
\hline \multirow[t]{2}{*}{25} & 13.56 & & & 28.28 & & 7.13 \\
\hline & & \multirow{2}{*}{\multicolumn{2}{|c|}{ Linha 2}} & & & \\
\hline 1 & 20.00 & & & 8.05 & & 4.37 \\
\hline 2 & 22.76 & 35.63 & 23.68 & 21.84 & 8.97 & 1.61 \\
\hline 3 & 20.00 & & & 10.80 & & -9.43 \\
\hline 4 & 20.00 & & & 8.05 & & -1.61 \\
\hline 5 & 24.60 & & & 12.64 & & 3.45 \\
\hline 6 & 20.00 & & & 9.89 & & -10.34 \\
\hline 7 & 22.76 & & & 100.00 & & 4.37 \\
\hline 8 & 21.84 & 36.55 & & 14.94 & & 100.00 \\
\hline 9 & 22.76 & & 24.60 & 14.48 & 8.97 & 3.45 \\
\hline 10 & 24.60 & & & 12.64 & & 1.61 \\
\hline 11 & 19.08 & & & 12.64 & & -0.23 \\
\hline 12 & 19.08 & & & 9.89 & & -1.15 \\
\hline 13 & 18.16 & & & 8.05 & & -2.07 \\
\hline 14 & 20.00 & & & 31.95 & & 20.92 \\
\hline 15 & 21.84 & & & 27.36 & & 31.03 \\
\hline 16 & 20.00 & 31.95 & 22.76 & 6.21 & 49.43 & 4.37 \\
\hline 17 & 21.84 & & & 20.92 & & 1.61 \\
\hline 18 & 15.40 & & & 14.48 & & -4.83 \\
\hline 19 & 21.84 & & & 12.64 & & 3.45 \\
\hline 20 & 21.84 & & & 14.94 & & 4.37 \\
\hline 21 & 20.00 & & & 12.64 & & -1.15 \\
\hline 22 & 19.08 & & & 8.05 & & 1.61 \\
\hline 23 & 20.92 & & & 10.80 & & 2.53 \\
\hline 24 & 20.00 & 35.63 & 25.52 & 11.72 & 8.05 & 3.45 \\
\hline 25 & 20.00 & & & 18.16 & & 100.00 \\
\hline & & & Linha 3 & & & \\
\hline 1 & 44.83 & & & 4.37 & & 8.05 \\
\hline 2 & 15.40 & & & 8.97 & & 9.89 \\
\hline 3 & 14.48 & & & 3.45 & & 47.59 \\
\hline 4 & 14.48 & & & 8.05 & & 3.45 \\
\hline 5 & 21.84 & & & 10.80 & & 6.21 \\
\hline 6 & 13.56 & & & 8.05 & & 4.37 \\
\hline 7 & 15.40 & & & 51.72 & & 6.21 \\
\hline 8 & 15.40 & & & 7.13 & & 6.21 \\
\hline 9 & 10.80 & & & 5.75 & & 2.53 \\
\hline 10 & 15.40 & & & 5.75 & & 12.64 \\
\hline 11 & 15.40 & & & 6.21 & & 6.21 \\
\hline 12 & 10.80 & & & 3.45 & & -2.07 \\
\hline 13 & 12.64 & & & 12.64 & & 5.29 \\
\hline 14 & 14.48 & & & 24.60 & & 7.13 \\
\hline 15 & 12.64 & & & 51.72 & & 0.69 \\
\hline 16 & 11.72 & & & 3.45 & & 2.53 \\
\hline 17 & 12.64 & & & 7.13 & & 4.37 \\
\hline 18 & 12.64 & & & 41.15 & & 5.29 \\
\hline 19 & 17.24 & & & 8.05 & & 6.21 \\
\hline 20 & 12.64 & & & 17.24 & & 2.53 \\
\hline 21 & 10.80 & & & 5.29 & & 4.37 \\
\hline 22 & 11.72 & & & 4.37 & & -1.15 \\
\hline 23 & 15.40 & & & 5.29 & & 9.89 \\
\hline 24 & 12.64 & & & 23.68 & & 10.80 \\
\hline 25 & 17.24 & & & 3.45 & & 8.97 \\
\hline
\end{tabular}


Anexo K - Graus de entupimento do modelo B no tratamento com cloração, obtidos a partir de avaliações de amostrais e completas de vazão, depois da aplicação de água residuária realizada na terceira etapa

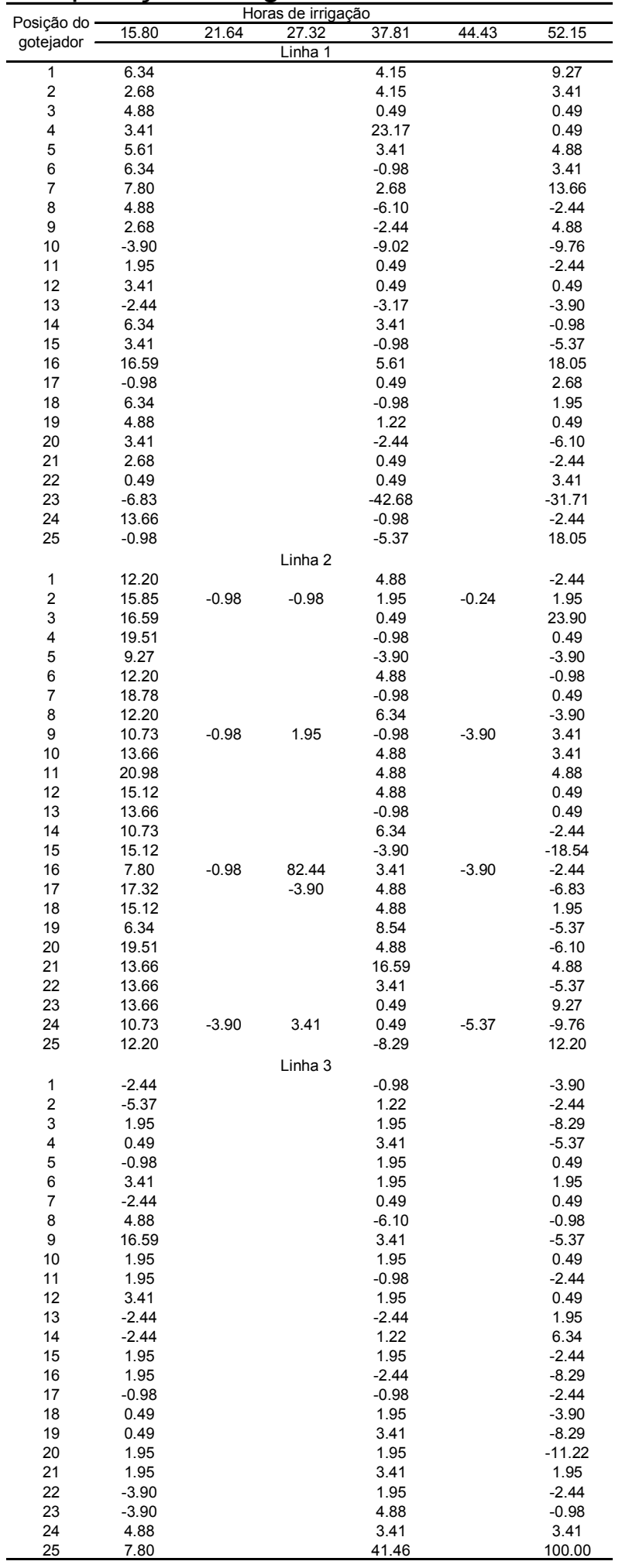


Anexo L - Graus de entupimento do modelo $M$ no tratamento com ar comprimido, obtidos a partir de avaliações de amostrais e completas de vazão, depois da aplicação de água residuária realizada na terceira etapa

\begin{tabular}{|c|c|c|c|c|c|c|}
\hline \multirow{3}{*}{$\begin{array}{l}\text { Posição do } \\
\text { gotejador }\end{array}$} & \multicolumn{5}{|c|}{ Horas de irrigação } & \multirow{3}{*}{52.15} \\
\hline & 15.80 & 21.64 & 27.32 & 37.81 & 44.43 & \\
\hline & & & \multicolumn{3}{|l|}{ Linha 1} & \\
\hline 1 & 13.71 & & \multirow{2}{*}{\multicolumn{3}{|c|}{$\begin{array}{c}5.62 \\
-13.26\end{array}$}} & 0.22 \\
\hline 2 & 8.31 & & & & & -10.56 \\
\hline 3 & 8.31 & & \multicolumn{3}{|c|}{5.62} & -5.17 \\
\hline 4 & 2.92 & & & -14.61 & & -7.87 \\
\hline 5 & -2.47 & & & -7.87 & & -7.87 \\
\hline 6 & 8.31 & & & -15.96 & & -5.17 \\
\hline 7 & 8.31 & & & -14.61 & & -5.17 \\
\hline 8 & 11.01 & & & 2.92 & & -7.87 \\
\hline 9 & 1.57 & & & -10.56 & & -7.87 \\
\hline 10 & 0.22 & & & -15.96 & & -5.17 \\
\hline 11 & 0.22 & & & -14.61 & & -10.56 \\
\hline 12 & 0.22 & & & -18.65 & & -7.87 \\
\hline 13 & -2.47 & & & -13.26 & & -10.56 \\
\hline 14 & 0.22 & & & -2.47 & & -10.56 \\
\hline 15 & 2.92 & & & -15.96 & & -5.17 \\
\hline 16 & 0.22 & & & -7.87 & & -7.87 \\
\hline 17 & 5.62 & & & -10.56 & & -7.87 \\
\hline 18 & -5.17 & & & -5.17 & & 8.31 \\
\hline 19 & 0.22 & & & -10.56 & & -2.47 \\
\hline 20 & 5.62 & & & -10.56 & & 8.31 \\
\hline 21 & 5.62 & & & -13.26 & & 8.31 \\
\hline 22 & 2.92 & & & -7.87 & & -2.47 \\
\hline 23 & 5.62 & & & -10.56 & & 8.31 \\
\hline 24 & 5.62 & & & -15.96 & & -7.87 \\
\hline 25 & 19.10 & & & -13.26 & & 2.92 \\
\hline & & & Linha 2 & & & \\
\hline 1 & 2.92 & & & -7.87 & & 5.62 \\
\hline 2 & 0.22 & 21.80 & 21.80 & 8.31 & 4.27 & -7.87 \\
\hline 3 & 2.92 & & & -15.96 & & -10.56 \\
\hline 4 & 5.62 & & & -5.17 & & 2.92 \\
\hline 5 & 5.62 & & & -15.96 & & -5.17 \\
\hline 6 & 0.22 & & & -13.26 & & -7.87 \\
\hline 7 & 2.92 & & & 0.22 & & -7.87 \\
\hline 8 & 12.36 & 19.10 & 27.19 & -10.56 & -6.52 & -7.87 \\
\hline 9 & -13.26 & & & -15.96 & & -13.26 \\
\hline 10 & -13.26 & & & -7.87 & & -7.87 \\
\hline 11 & 5.62 & & & -7.87 & & -7.87 \\
\hline 12 & 8.31 & & & 21.80 & & -2.47 \\
\hline 13 & 2.92 & & & 8.31 & & 100.00 \\
\hline 14 & 0.22 & & & -7.87 & & -2.47 \\
\hline 15 & 8.31 & & & -18.65 & & -2.47 \\
\hline 16 & 5.62 & 21.80 & 19.10 & 0.22 & -5.17 & 0.22 \\
\hline 17 & 2.92 & & & -5.17 & & 2.92 \\
\hline 18 & 5.62 & & & -10.56 & & 0.22 \\
\hline 19 & 5.62 & & & 0.22 & & -5.17 \\
\hline 20 & 2.92 & & & -14.61 & & -7.87 \\
\hline 21 & 0.22 & & & -15.96 & & -5.17 \\
\hline 22 & 5.62 & & & -7.87 & & -2.47 \\
\hline 23 & 5.62 & & & -10.56 & & -18.65 \\
\hline 24 & 2.92 & 24.49 & 11.01 & -5.17 & -6.52 & -7.87 \\
\hline 25 & 0.22 & & & -7.87 & & -7.87 \\
\hline & & & Linha 3 & & & \\
\hline 1 & 13.71 & & & -2.47 & & 33.69 \\
\hline 2 & 11.01 & & & 0.22 & & 20.43 \\
\hline 3 & 5.62 & & & 0.22 & & 17.77 \\
\hline 4 & 11.01 & & & -5.17 & & 17.77 \\
\hline 5 & 13.71 & & & 100.00 & & 100.00 \\
\hline 6 & 27.19 & & & 8.31 & & 20.43 \\
\hline 7 & 5.62 & & & -5.17 & & 15.12 \\
\hline 8 & 16.40 & & & 5.62 & & -59.15 \\
\hline 9 & 0.22 & & & -7.87 & & 20.43 \\
\hline 10 & 5.62 & & & 5.62 & & 15.12 \\
\hline 11 & 13.71 & & & -18.65 & & 17.77 \\
\hline 12 & 5.62 & & & -5.17 & & 20.43 \\
\hline 13 & -5.17 & & & 5.62 & & 7.16 \\
\hline 14 & 13.71 & & & -2.47 & & 15.12 \\
\hline 15 & 29.89 & & & -2.47 & & 20.43 \\
\hline 16 & 17.75 & & & -5.17 & & 15.12 \\
\hline 17 & 13.71 & & & 0.22 & & 20.43 \\
\hline 18 & 8.31 & & & 2.92 & & 17.77 \\
\hline 19 & 16.40 & & & -5.17 & & 20.43 \\
\hline 20 & 5.62 & & & -5.17 & & 20.43 \\
\hline 21 & 0.22 & & & -7.87 & & -3.45 \\
\hline 22 & 5.62 & & & -2.47 & & 12.47 \\
\hline 23 & 5.62 & & & 2.92 & & 20.43 \\
\hline 24 & 8.31 & & & -14.61 & & 15.12 \\
\hline 25 & 6.97 & & & 2.92 & & 17.77 \\
\hline
\end{tabular}


Anexo M - Graus de entupimento do modelo $E$ no tratamento com ar comprimido, obtidos a partir de avaliações de amostrais e completas de vazão, depois da aplicação de água residuária realizada na terceira etapa

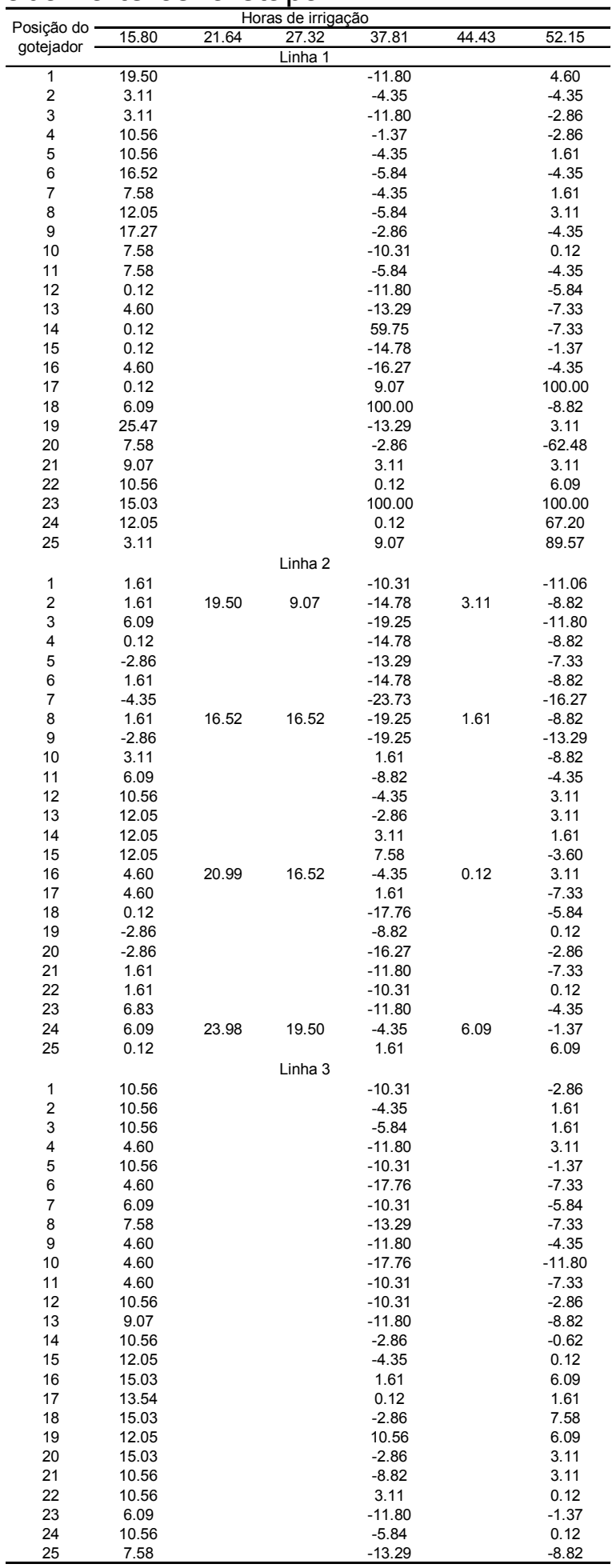


Anexo N - Graus de entupimento do modelo D no tratamento com ar comprimido, obtidos a partir de avaliações de amostrais e completas de vazão, depois da aplicação de água residuária realizada na terceira etapa

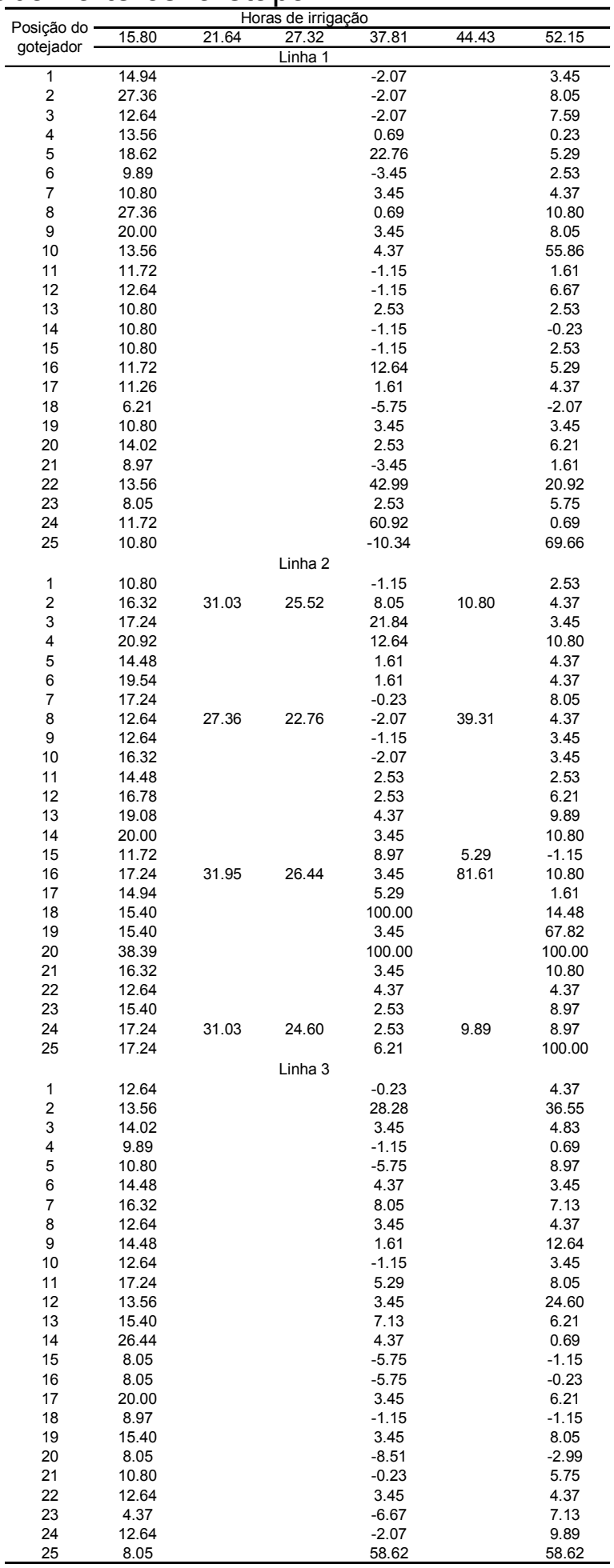


Anexo O - Graus de entupimento do modelo B no tratamento com ar comprimido, obtidos a partir de avaliações de amostrais e completas de vazão, depois da aplicação de água residuária realizada na terceira etapa

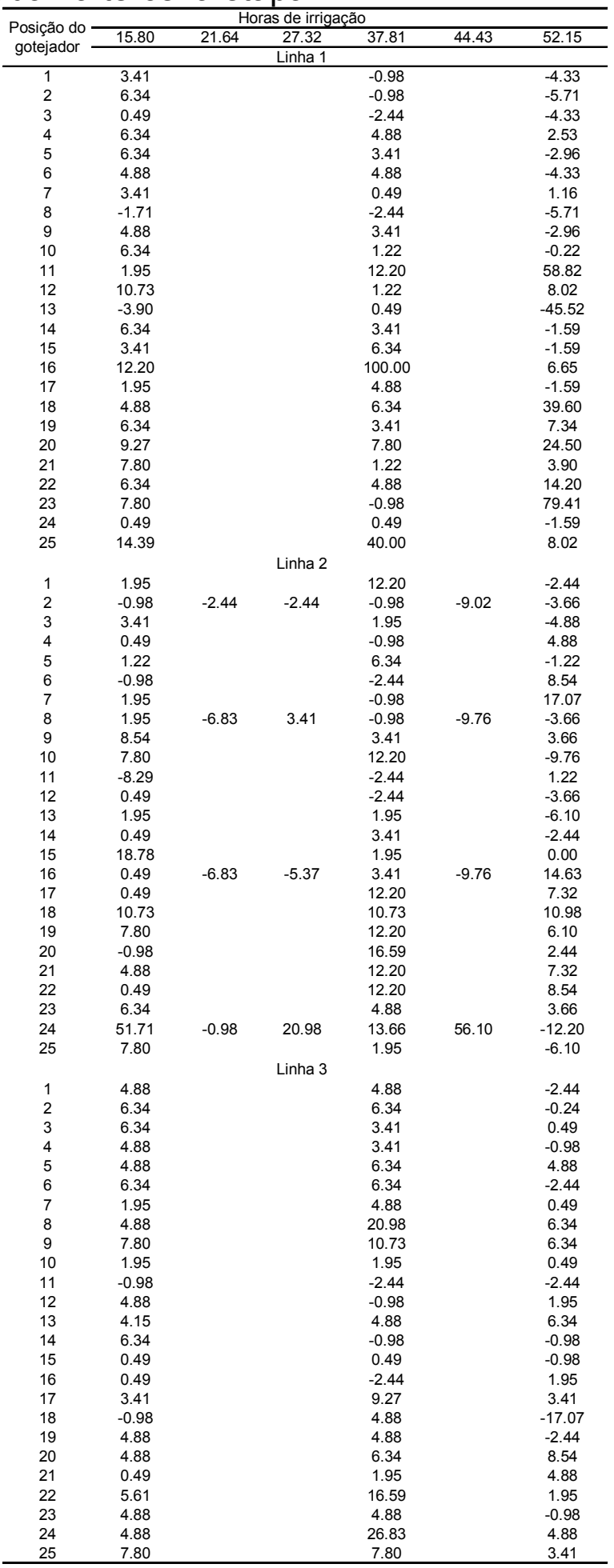


Anexo P - Graus de entupimento do modelo M no tratamento com cloração e ar comprimido, obtidos a partir de avaliações de amostrais e completas de vazão, depois da aplicação de água residuária realizada na terceira etapa

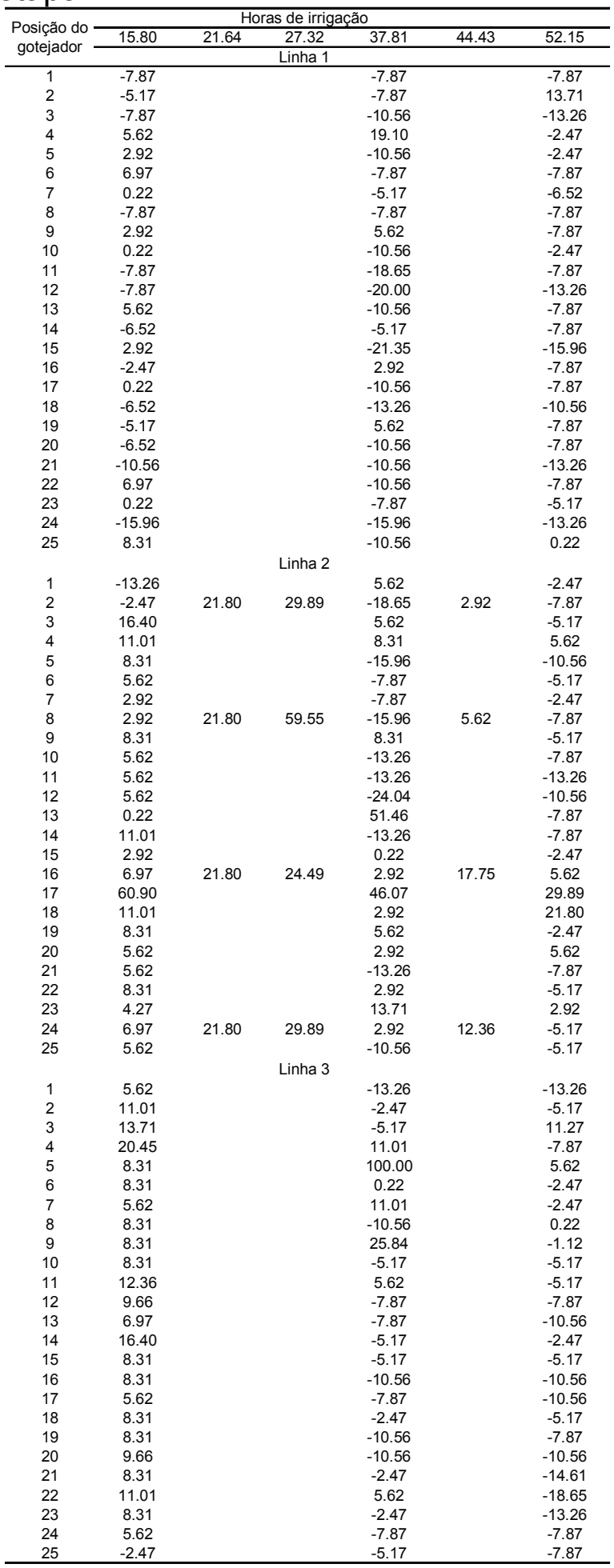


Anexo Q - Graus de entupimento do modelo $E$ no tratamento com cloração e ar comprimido, obtidos a partir de avaliações de amostrais e completas de vazão, depois da aplicação de água residuária realizada na terceira etapa

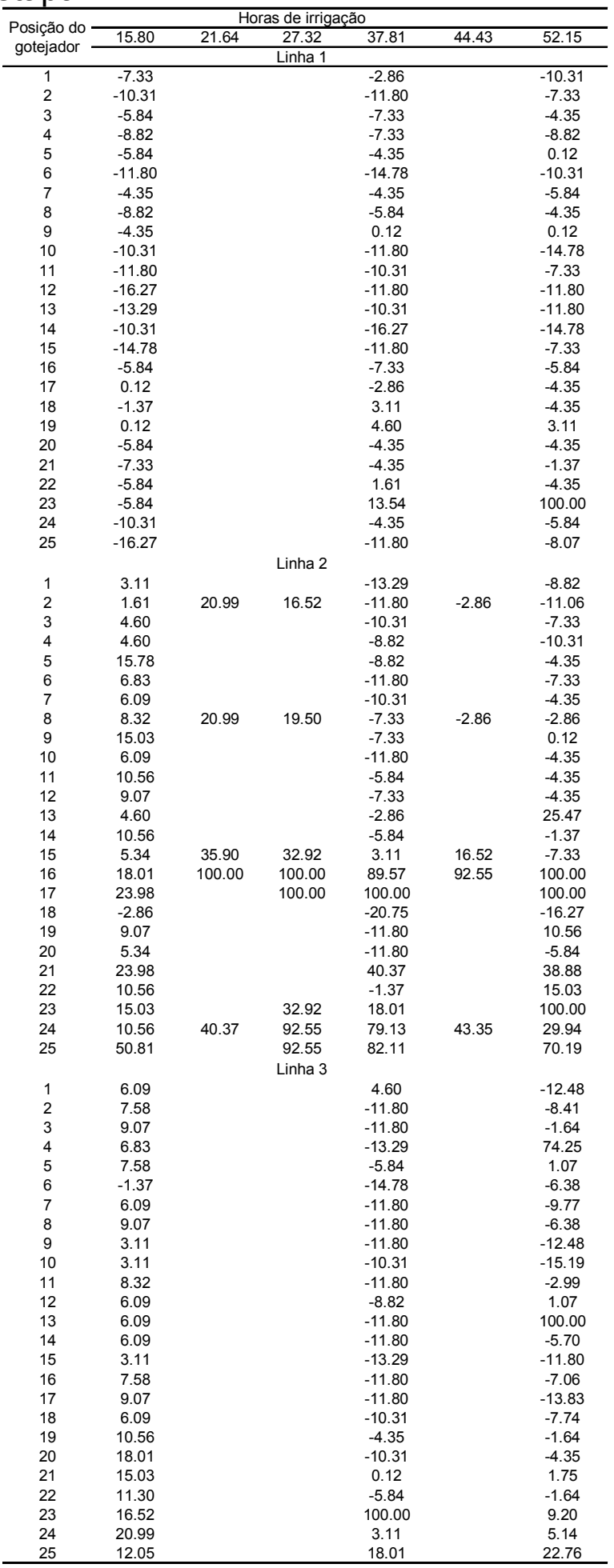


Anexo R - Graus de entupimento do modelo D no tratamento com cloração e ar comprimido, obtidos a partir de avaliações de amostrais e completas de vazão, depois da aplicação de água residuária realizada na terceira etapa

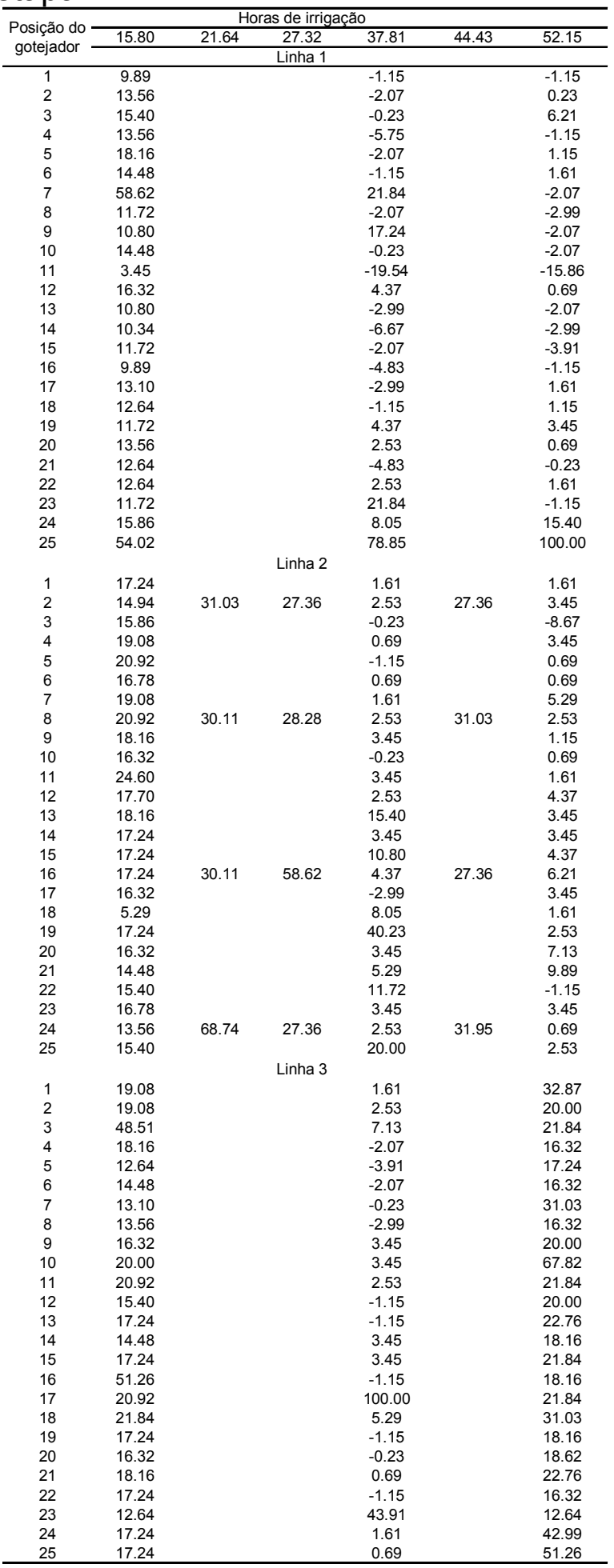


Anexo S - Graus de entupimento do modelo B no tratamento com cloração e ar comprimido, obtidos a partir de avaliações de amostrais e completas de vazão, depois da aplicação de água residuária realizada na terceira etapa

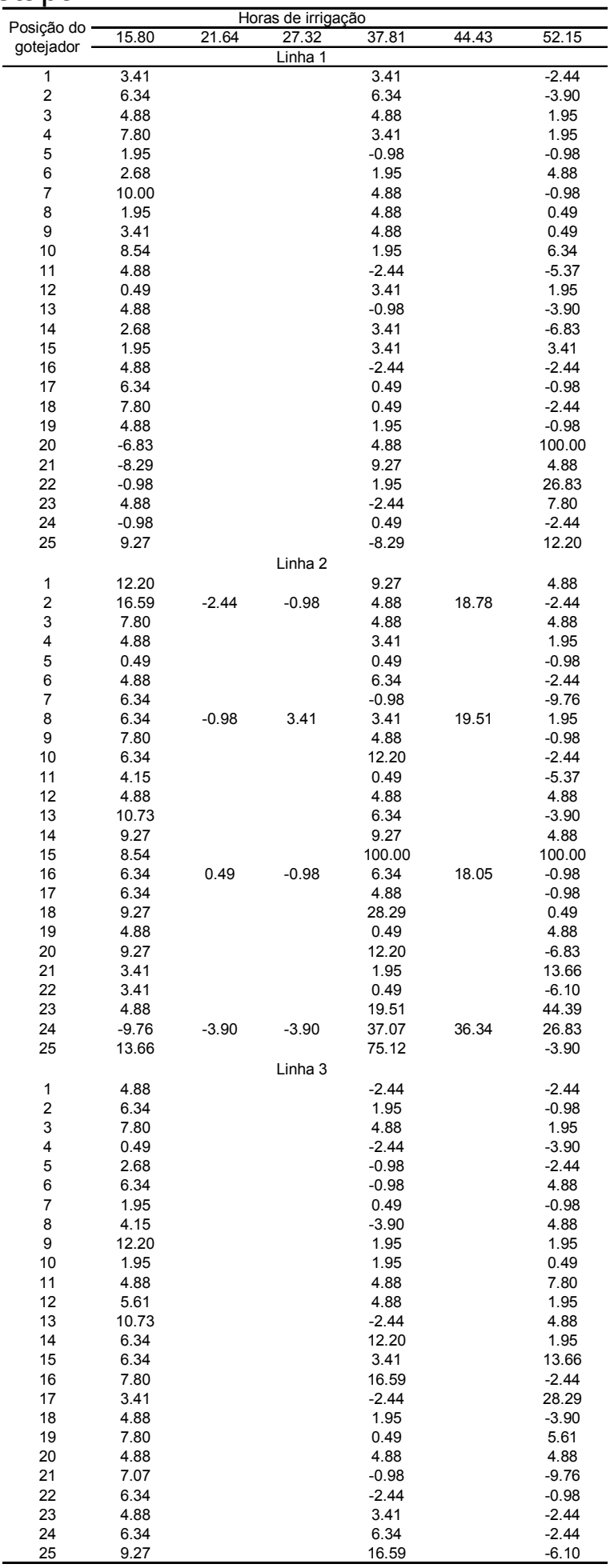


Anexo T - Resultado gráfico para análise de probabilidades de encontrar valores de vazão na faixa de $\pm 5 \%$ de variação em relação à vazão dos emissores quando novos (área hachurada) para os diferentes modelos de gotejadores utilizados na terceira etapa

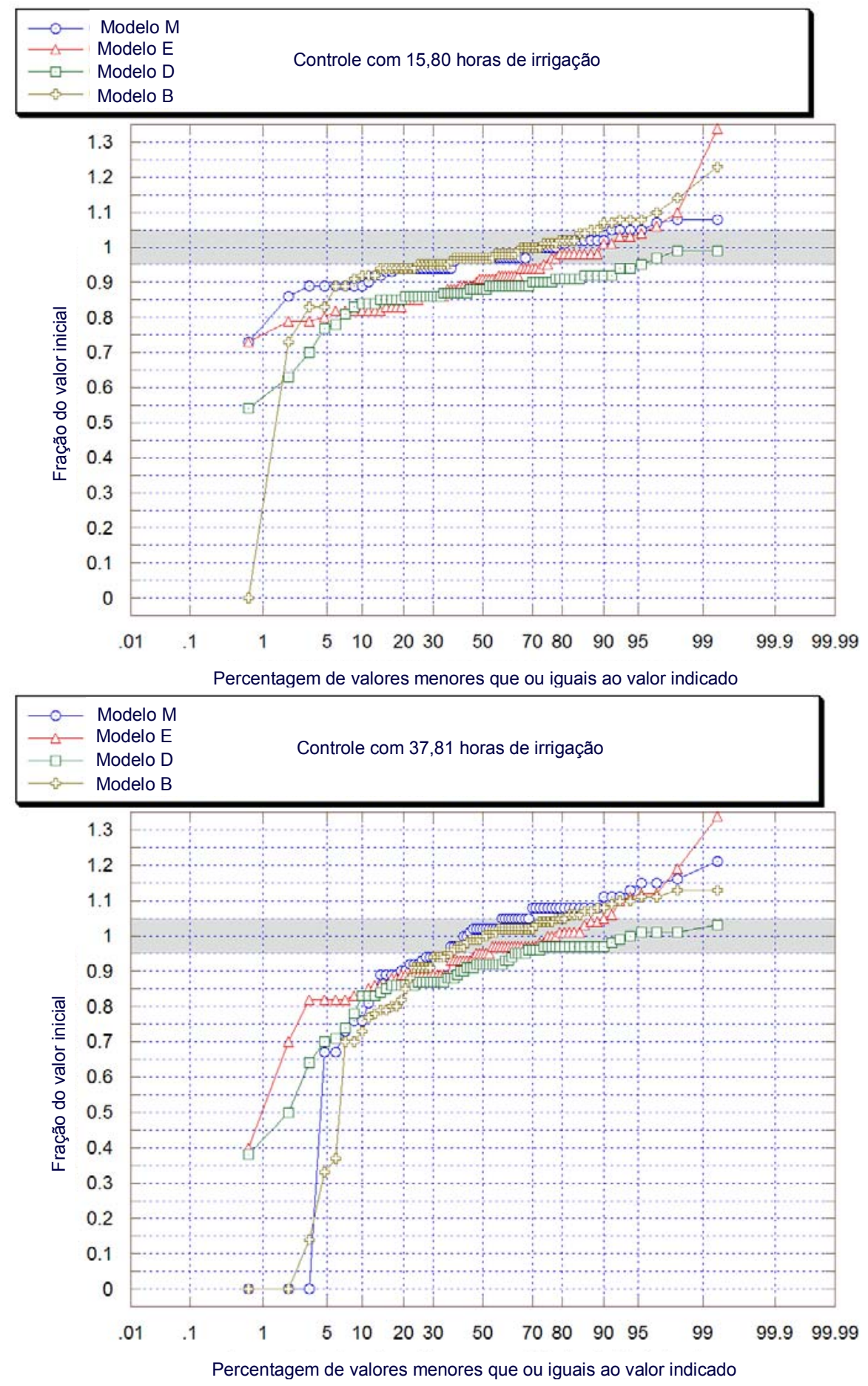


Anexo T - Resultado gráfico para análise de probabilidades de encontrar valores de vazão na faixa de $\pm 5 \%$ de variação em relação à vazão dos emissores quando novos (área hachurada) para os diferentes modelos de gotejadores utilizados na terceira etapa
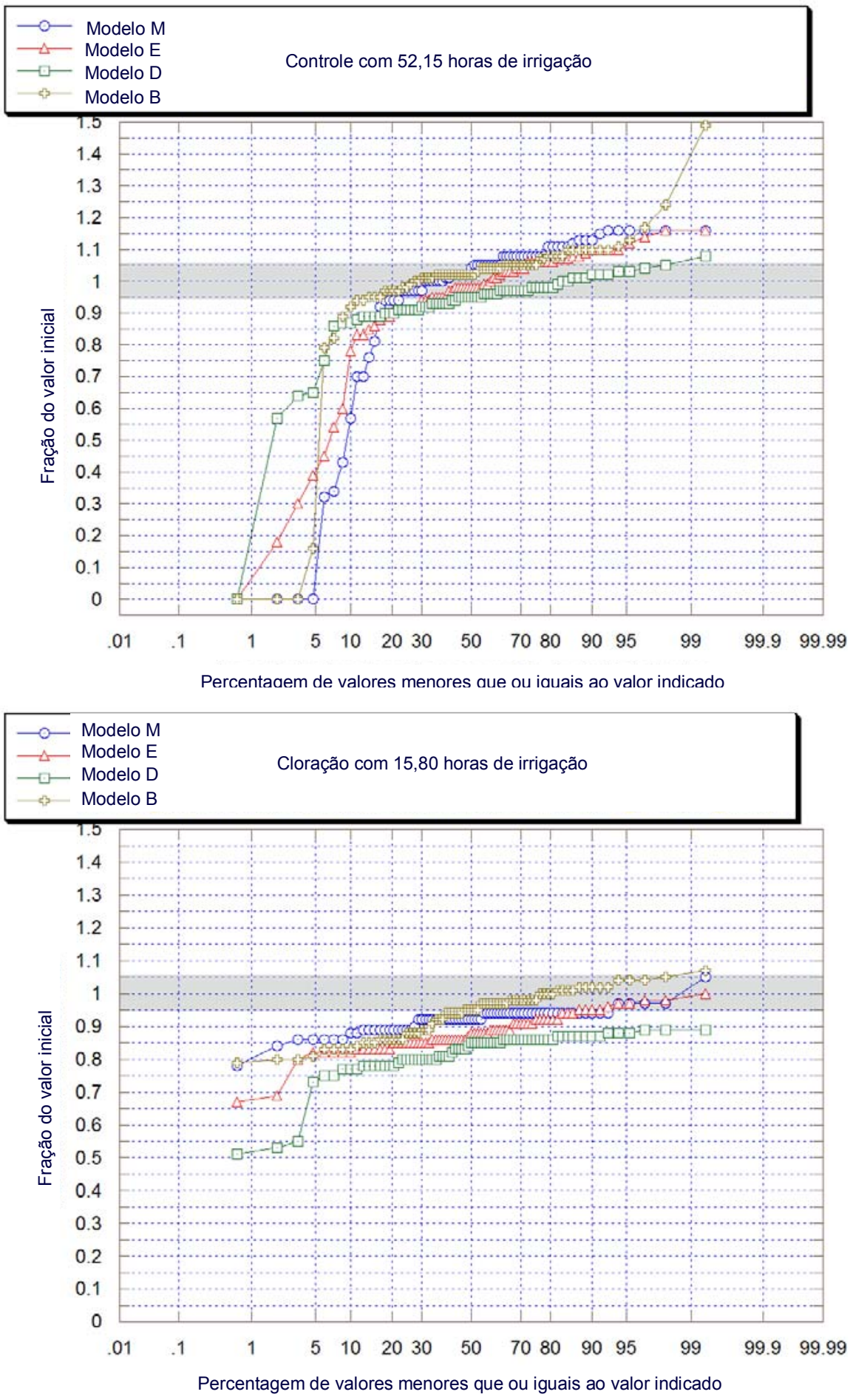
Anexo T - Resultado gráfico para análise de probabilidades de encontrar valores de vazão na faixa de $\pm 5 \%$ de variação em relação à vazão dos emissores quando novos (área hachurada) para os diferentes modelos de gotejadores utilizados na terceira etapa
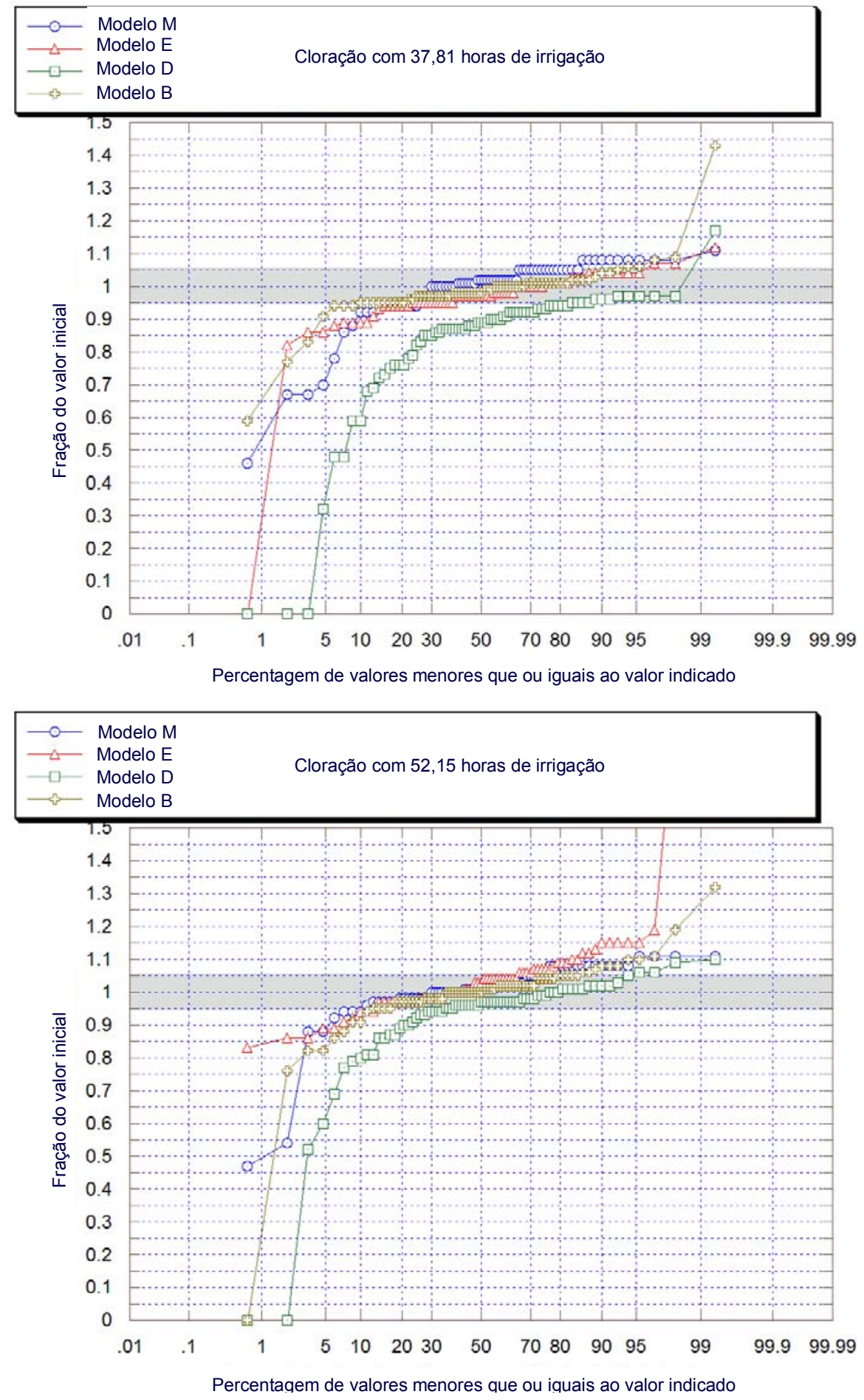
Anexo T - Resultado gráfico para análise de probabilidades de encontrar valores de vazão na faixa de $\pm 5 \%$ de variação em relação à vazão dos emissores quando novos (área hachurada) para os diferentes modelos de gotejadores utilizados na terceira etapa
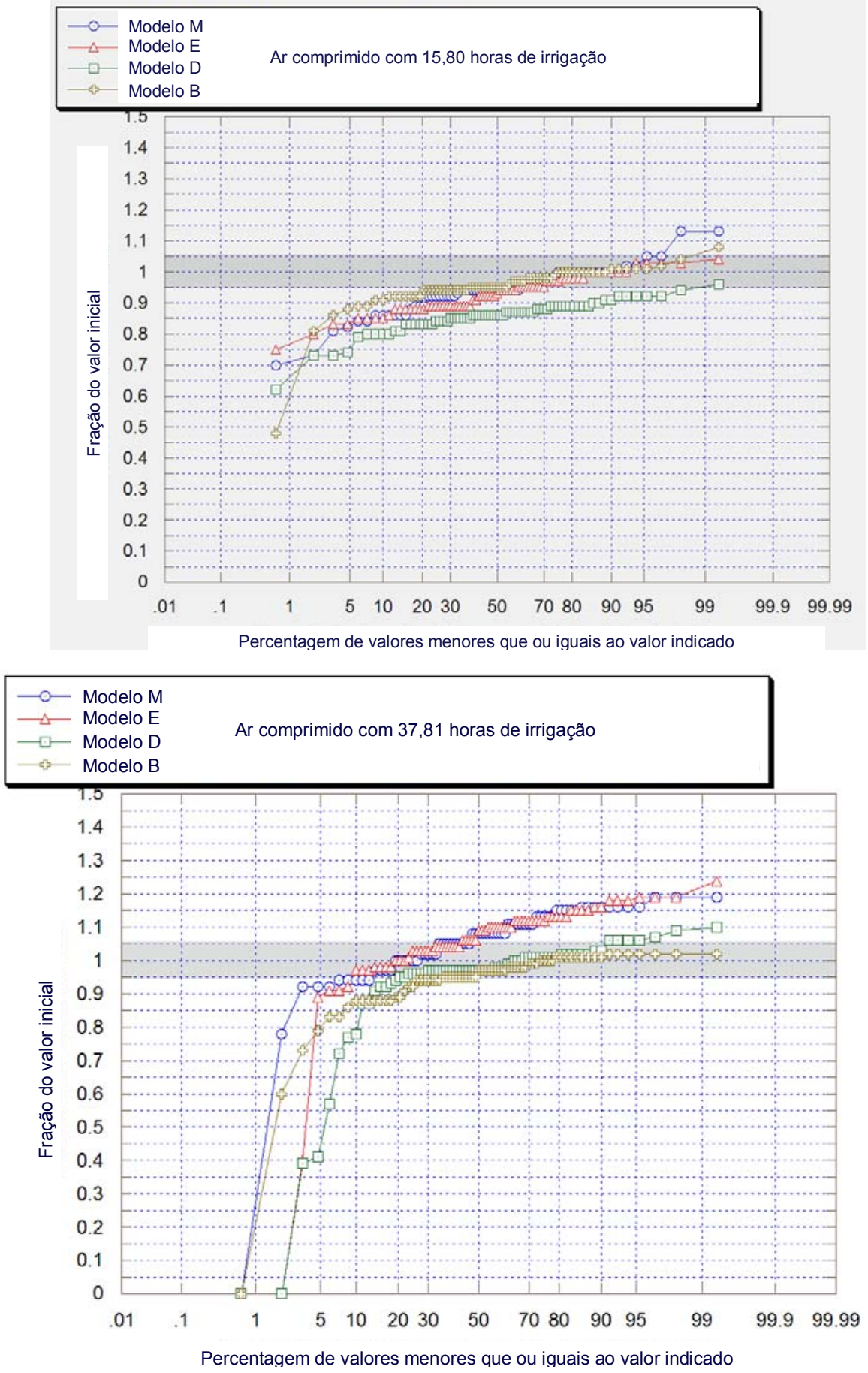
Anexo T - Resultado gráfico para análise de probabilidades de encontrar valores de vazão na faixa de $\pm 5 \%$ de variação em relação à vazão dos emissores quando novos (área hachurada) para os diferentes modelos de gotejadores utilizados na terceira etapa
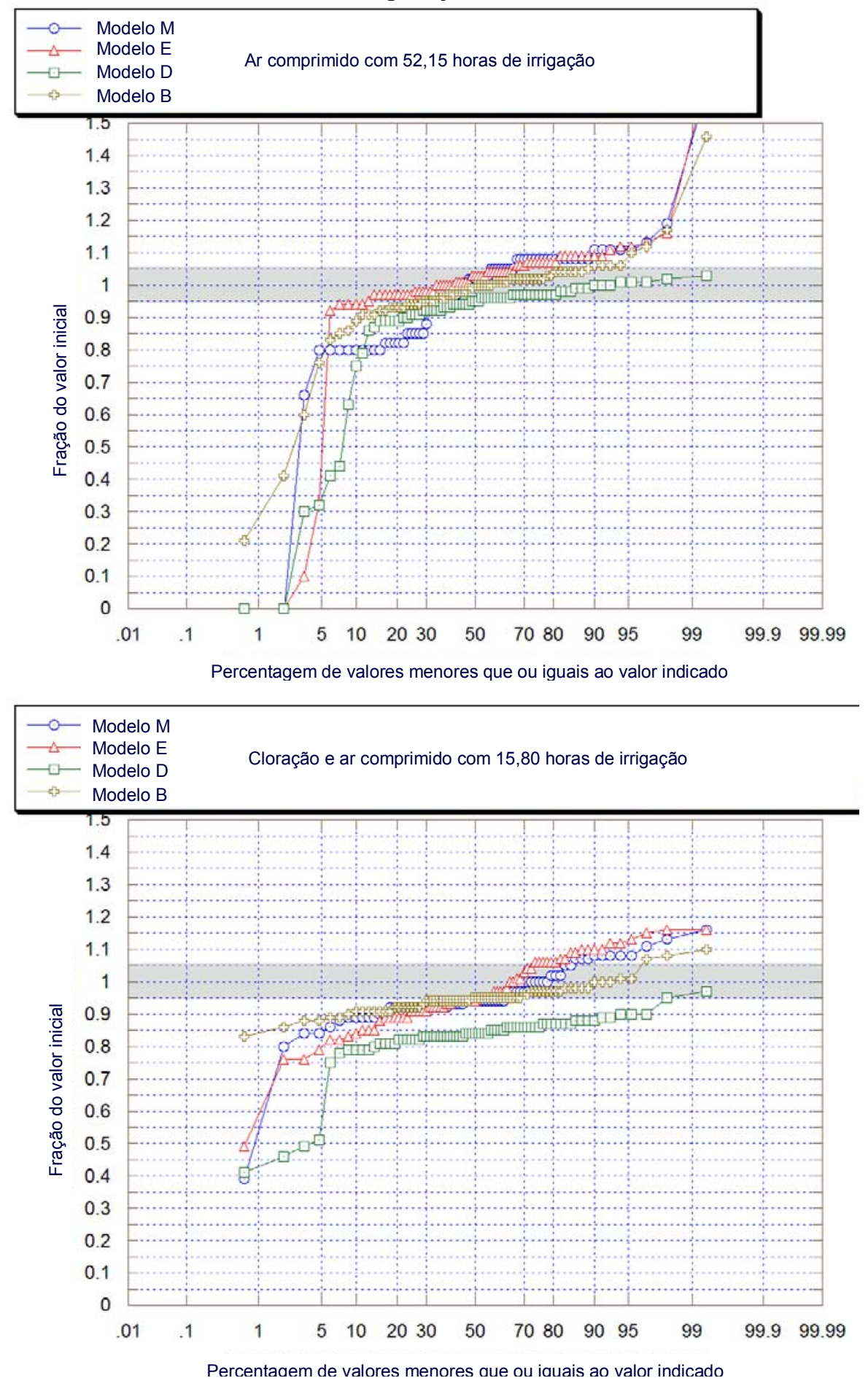
Anexo T - Resultado gráfico para análise de probabilidades de encontrar valores de vazão na faixa de $\pm 5 \%$ de variação em relação à vazão dos emissores quando novos (área hachurada) para os diferentes modelos de gotejadores utilizados na terceira etapa
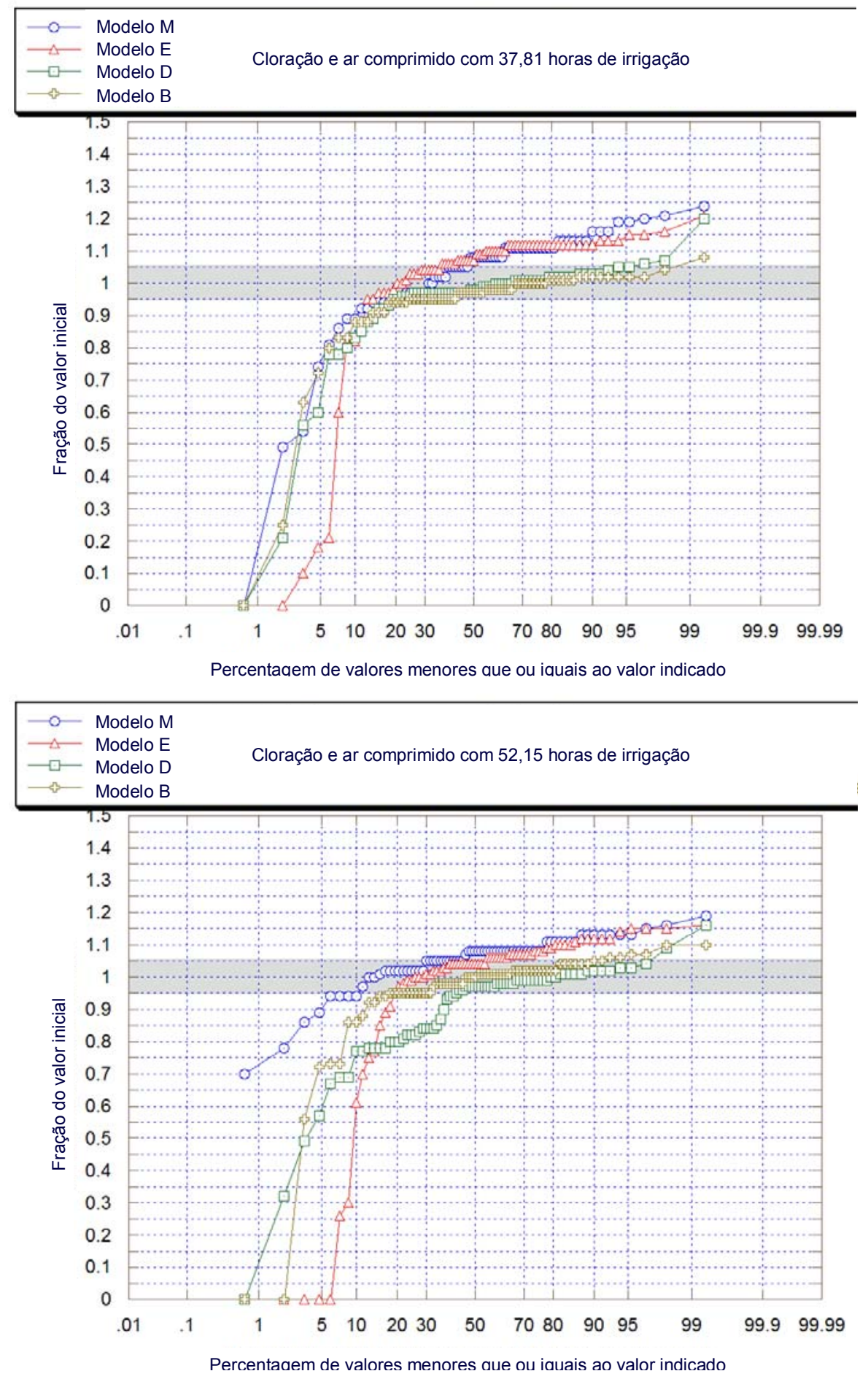


\section{REFERÊNCIAS BIBLIOGRÁFICAS}

ADIN, A. Problems associated with particulate matter in water reuse for agricultural irrigation and their prevention. Water Science and Technology, v.18, n.9, p.185-195, 1986.

ADIN, A.; ELIMELECH, M. Particle filtration for wastewater irrigation. Journal of Irrigation and Drainage Engineering, v.115, n.3, p.474-487, 1989.

ADIN, A.; SACKS, M. Dripper clogging factors in wastewater irrigation. Journal of Irrigation and Drainage Engineering. v.117, n.6, p.813-826, 1991.

AIROLDI, R. P. S. Eficiência dos meios filtrantes disco e manta sintética não tecida em fertirrigação por gotejamento. Campinas, 2003. 189p. Dissertação (Mestrado) - Faculdade de Engenharia Agrícola, Universidade Estadual de Campinas.

AL-NAKSHABANDI, G.A.; SAQQAR, M.M.; SHATANAWI, M.R.; FAYYAD, M.; AL-HORANI, H. Some environmental problems associated with the use of treated wastewater for irrigation in Jordan. Agricultural and Water Management, v.34, n.1, p.81-94, 1997.

ALI, I. Wastewater criteria for irrigation in arid regions. Journal of Irrigation and Drainage Engineering. v.113, n.2, p.173-83, 1987.

American Society of Agricultural Engineers - ASAE. Field evaluation of microirrigation systems : standard EP458. St. Joseph, 1988. 7p. 
AVNIMELECH, Y.; DIAB, S.; KOCHBA, M. Development and evaluation of a biofilter for turbid and nitrogen rich irrigation water. Water Research. v.27, n.5, p.785-790, 1993.

AYERS, R.S.; WESTCOT, D.W. A qualidade da água na agricultura. Tradução de R.S. Gheyi et al. Campina Grande : UFPB, 1999. 218p. (Estudos FAO: Irrigação e Drenagem, 29).

BARBAGALLO, S.; BUTTAFUOCO, G. Prove di microerogatori per lúso di acque reflue urbane. Rivista di Ingegneria Agraria, v.29, n.4, p.193-201, 1998.

BASTOS, R.K.X. Fertirrigação com águas residuárias. In : FOLEGATTI, M. V. (Coord.) Fertirrigação - citrus, flores, hortaliças. Guaíba: Agropecuária, 1999. p.279-291.

BERNARDO, S. Manual de irrigação. 6.ed. Viçosa : UFV, 1995. 657p.

BOUWER, H.; IDELOVITCH, E. Quality requirements for irrigation with sewage water. Journal of Irrigation and Drainage Engineering. v.113, n.4, p.516-535, 1987.

BRALTS, V.F. Operational principles. In: NAKAYAMA, F.S.; BUCKS, D.A. Trickle irrigation for crop production: depelopment in agricultural engineering. Amsterdam : Elsevier, 1986. p.230-239.

BUCKS, D.A.; NAKAYAMA, F.S.; GILBERT, R.G. Trickle irrigation water quality and preventive maintenance. Agricultural and Water Management, v.2, p.149-162, 1979.

CAPRA, A.; SCICOLONE, B. Water quality and distribution uniformity in drip / trickle irrigation systems. Journal of Agricultural Engineering Research, v.70, n.4, p.355-365, 1998. 
CHANDRAKANTH, M.S.; LAU, L.S.; WU, I.P. Plugging evaluation in reuse of primary wastewater effluent for drip irrigation. In: INTERNATIONAL MICROIRRIGATION CONGRESS, 4., Albury, 1988. Proceedings. p.211-218, 1988.

CARARO, D.C.; LEVERENZ, L.H.; BOTREL, T.A. ; HILLS, D.J. Efeitos de ácido peróxido acético, hipoclorito de sódio e filtro textil na minimização do entupimento de gotejadores pelo uso de água residuária de tanque séptico. In : CONGRESSO BRASILEIRO DE ENGENHARIA AGRÍCOLA, 33., São Pedro (Compact disc) Campinas : SBEA, 2004.

CICERO, S.; PUMO, D.; HAMDY, A. Experimental study on drip irrigation with reclaimed waste water. In : CENTRE INTERNATIONAL DE HAUTE ETUDES AGROMIQUEST MEDITTRANEENNES INTERNATIONAL CONFERENCE. Wastewater re-use in irrigated agriculture. Water management, salinity and pollution control towards sustainable irrigation in the Mediterranean Region. Paris: 1997. p.195-211.

CLOETE, T.E. Biofouling control in industrial water systems: what we know and what we need to know. Materials and Korrosion-Werkstoffe und Korrosion. v.54, n.7, p.520-526, 2003.

CORREA, J.F. Evaluation of hydraulic characteristics of emitters. In: INTERNATIONAL CONGRESS ON THE USE OF PLASTICS IN AGRICULTURE, 11., New Delhi, 1990. Proceedings. Rotterdam. 1990. p.137-143.

COSTA, C.C. da. Estudo da susceptibilidade de tubos gotejadores ao entupimento por precipitados químicos de ferro. Lavras, 2000. 85p. Dissertação (Mestrado) - Universidade Federal de Lavras. 
DIAB, S.; KOCHBA, M.; AVNIMELECH, Y. Development of a biofilter for turbid and nitrogen-rich irrigation water - $\mathrm{B}$ : removal of phosphorus, algae and clay. Bioresource Technology. v.44, n.2, p.137-140, 1993.

DOORENBOS, J. KASSAM, A. H. Yield response to water. Rome: FAO, 1979. 193p. (Estudos FAO: Irrigação e Drenagem, 33).

GILBERT, R.G.; FORD, H.W. Operational principles / emitter clogging. In: NAKAYAMA, F.S.; BUCKS, D.A. Trickle irrigation for crop production: design, operation and management. Amsterdam: Elsevier, 1986. p.142163.

GILBERT, R.G.; NAKAYAMA, F.S.; BUCKS, D.A. Trickle irrigation: prevention of clogging. Transactions of the ASAE, v.22, p.514-519, 1979.

GILBERT, R.G.; NAKAYAMA, F.S.; BUCKS, D.A.; FRENCH, O.F.; ADAMSON, K.C. Trickle irrigation: emitter clogging and other flow problems. Agricultural and Water Management. v.3, p.159-178, 1980.

GILBERT, R.G.; NAKAYAMA, F.S.; BUCKS, D.A.; FRENCH, O.F.; ADAMSON, K.C.; JOHNSON, R.M. Trickle irrigation: predominant bacteria in treated Colorado River water and biologically clogged emitters. Irrigation Science, v.3, p.123-132, 1982.

HAMODA, M.F.; AL-AWADI, S.M. Improvement of effluent quality for reuse in a dairy farm. Water Science Technology, v.33, n.10, p.79-85, 1996.

HANSON, B.R.; LAMM, F.R. Drip irrigation of row crops: an overview. INTERNATIONAL MICROIRRIGATION CONGRESS, 5., Orlando, 1995. Proceedings. St. Joseph: ASAE, 1995. p.651-655. 
HASSEN, A.; MAHROUK, M.; OUSARI, H.; CHERIF, M.; BOUDABOUS, A.; DAMELINCOURT, J.J. UV desinfection of treated wastewater in a largescale pilot plant and inactivation of selected bacteria in a laboratory UV device. Bioresource Technology, v.74, p.141-150, 2000.

HILLS, D.J.; BRENES, M.J. Microirrigation of wastewater effluent using drip tape. Applied Engineering in Agriculture. v.17, n.3, p. 303-308, 2001.

HILLS, D.J.; EL-EBABY, F.G. Evaluation of microirrigation self-cleaning emitters. Applied Engineering in Agriculture. v.6, n.4, p.441-445, 1990.

HILLS, D.J.; TAJRISHY, M.A.; TCHOBANOGLOUS, G. The influence of filtration on ultraviolet disinfection of secondary effluent for microirrigation. Transactions of the ASAE, v.43, n.6, p.1499-1505, 2000.

JACKSON, R.C.; KAY, M.G. Use of pulse irrigation for reducing clogging problems in trickle emitters. Journal of Agricultural Engineering Research, v.37, p.223-227, 1987.

KAY, M.G.; TYRREL, S.F.; HOWSAM, P. Biofouling in drip / trickle irrigation systems. In: RYDZEWSKI, J.R. Irrigation: theory and practice. London: Pentech Press, 1989. p.652-659.

KELLER, J.; BLIESNER, R.D. Sprinkle and trickle irrigation. New York : Van Nostrand Reinhold, 1990. 652p.

LAR, R.; STEWART, B.A. Soil processes and water quality. London: Lewis Publishers, 1994. 398p.

LEITE, J.A.O. Avaliação da susceptibilidade de tubogotejadores ao entupimento por precipitados químicos de carbonato de cálcio. Lavras, 1995. 64p. Dissertação (Mestrado) - Universidade Federal de Lavras. 
LÉON S., G.; CAVALLINI, J.M. Tratamento e uso de águas residuárias. Tradução de H.R. Gueyi et al. Campina Grande: UFPB, 1999. 110p.

LOPEZ, R.J.; ABREU, J.M.H.; REGALADO, A.P.; HERNANDEZ, J.F.G. Riego localizado. 2.ed. Madri: Mundi-Prensa, 1997. 405p.

MACEDO, L.H.H.; NOGUTI, M.; ABE, H.Y. Estudo dos trihalometanos. Revista DAE, n.134, p.42-47, 1983.

MANCUSO, P.C.S.; SANTOS, H.F. Reúso de água. Barueri: Manole, 2003, $576 p$.

MEDEIROS, S.D. de. Determinação da curva de retenção da água no solo através do fatiamento de amostras centrifugadas. Piracicaba, 1987. 66p. Dissertação (Mestrado) - Escola Superior de Agricultura "Luiz de Queiroz", Universidade de São Paulo.

METCALF \& EDDY. Wastewater engineering: treatment and reuse. Revisado por G. Tchobanoglous et al. 4.ed. New York: McGraw-Hill, 2003. 1819 p.

MEYER, J.L.; SNYDER, M.J.; VALENZUELA, L.H.; HARRIS, A. Liquid polymers keep drip irrigation lines from clogging. California Agriculture, v.45, n.1, p.24-25, 1991.

NAKAYAMA, F.S.; BUCKS, D.A. Emitter clogging effects on trickle irrigation uniformity. Transactions of the ASAE, v.1, p.77-80, 1981.

NAKAYAMA, F.S.; BUCKS, D.A. Water quality in drip/trickle irrigation: A review. Irrigation Science, v.12, p.187-192, 1991.

NAKAYAMA, F.S.; BUCKS, D.A., CLEMMENS, A.J. Assessing trickle emitter application uniformity. Transactions of the ASAE, v.22, n.4, p.816-821, 1979. 
NAKAYAMA, F.S.; BUCKS, D.A.; FRENCH, O.F. Reclaiming partially clogged trickle emitters. Transactions of the ASAE, v.20, p.278-280, 1977.

NAKAYAMA, F.S.; GILBERT, R.G.; BUCKS, D.A. Water treatments in trickle irrigation systems. Journal of the Irrigation and Drainage Division, v.104, p.23-34, 1978.

NEILSEN, G.H.; STEVENSON, D.S.; FITZPATRICK, J.J.; BROWNLEE, C.H. Yield and plant nutrient content of vegetables trickle-irrigated with municipal wastewater. HortScience, v.24, n.2, p.249-252, 1989a.

NEILSEN, G.H.; STEVENSON, D.S.; FITZPATRICK, J.J.; BROWNLEE, C.H. Nutrition and yield of young apple trees irrigated with municipal wastewater. Journal of the American Society for Horticultural Science, v.114, n.3, p.377-383, 1989b.

ORON, G.; SHELEF, G.; TURZYNSKI, B. Trickle irrigation using treated wastewaters. Journal of the Irrigation and Drainage Division, v.105, n.2, p.175-186, 1979.

ORON, G.; DeMALACH, Y.; HOFFMAN, Z.; MANOR, Y. Effect of effluent quality and application method on agricultural productivity and environmental control. Water Science and Technology, v.26, n.7/8, p.1593-1601, 1992.

PAPADOPOLOUS, I.; STYLIANOU, Y. Trickle irrigation of sunflower with municipal wastewater. Agricultural Water Management, v.19, p.67-75, 1991.

PARCHOMCHUK, P. Temperature effects on emitter discharge rates. Transactions of the ASAE, v.19, n.4, p.690-692, 1976.

PESCOD, M.D. Wastewater treatment and use in agriculture. Rome: FAO, 1992. 125p. (FAO. Irrigation and Drainage Paper, 47). 
PIZARRO, F. Riegos localizados de alta frequencia. 3.ed. Madri: Mundi Prensa, 1996. 513p.

POVOA, A.F.; HILLS, D.J. Sensitivity of microirrigation system pressure to emitter plugging and lateral line perfurations. Transactions of the ASAE, v.37, n.3, p.793-799, 1994.

RAV-ACHA, C.; KUMMEL, M.; SALAMON, I.; ADIN, A. The effect of chemical oxidants on effluent constitutents for drip irrigation. Water Research, v.29, n.1, p.119-129, 1995.

RAVINA, I.; PAZ, E.; SOFER, Z.; MARCU, A.; SCHISCHA, A.; SAGI, G. Control of emitter clogging in drip irrigation with reclaimed wastewater. Irrigation Science, v.13, p.129-139, 1992.

RAVINA, I.; PAZ, E.; SOFER, Z.; MARCU, A.; SCHISCHA, A.; SAGI, G.; YECHIALY, Z.; LEV, Y. Control of clogging in drip irrigation with stored treated municipal sewage effluent. Agricultural and Water Management, v.33, p.127-137, 1997.

RESENDE, R.S. Suscetibilidade de gotejadores ao entupimento de causa biológica e avaliação do desentupimento via cloração da água de irrigação. Piracicaba, 1999. 77p. Dissertação (Mestrado) - Escola Superior de Agricultura "Luiz de Queiroz", Universidade de São Paulo.

RESENDE, R.S. Intrusão radicular e efeito de vácuo em gotejamento enterrado na irrigação de cana-de-ácúcar. Piracicaba, 2003. 124p. Tese (Doutorado) - Escola Superior de Agricultura "Luiz de Queiroz", Universidade de São Paulo.

SAN JUAN, F.A.M. Riego por goteo. 4.ed. Madrid: Mundi-Prensa, 1996. $302 p$. 
SCALOPPI, E.J. Características dos principais sistemas de irrigação. ITEM Irrigação e Tecnologia Moderna, n.25, p.22-27, 1986.

SCHAKSCHOUK, A.M. Alleviation of chemical pollution resultant through water chemical treatment in trickle irrigation systems. Egyptian Journal of Soil Science, v.36, n.2, p.189-218, 1996.

SCHISCHA, A.; RAVINA, I.; SAGI, G.; PAZ, E.; YECHIELY, Z.; ALKON, A.; SCHRAMM, G.; SOFER, Z.; MARCU, A.; LEV, Y. Drip irrigation with reclaimed effluent - the clogging problems. 'The platform trials'test filters and emitter sensitivity. International Water and Irrigation Review, v.17, n.3, p.8-12, 1997.

SILVANAPPAN, R.K.; LAMM, F.R. Present status and future of microirrigation in India. INTERNATIONAL MICROIRRIGATION CONGRESS, 5, New Delhi, 1995. Proceedings. Saint Joseph: ASAE, 1995. p.740-744.

SMAJSTRLA, A.G. Prevention of microirrigation emitter clogging. In: SOUTH TEXAS IRRIGATION CONFERENCE, Hondo, 1991. Proceedings, Hondo: Texas Agricultural Extension Service, 1991. p.132-139.

SMAJSTRLA, A.G. Causes and prevention of emitter clogging in microirrigation systems. Irrigation Journal. p.14-17, Apr. 1995.

SOLOMON, K. Manufacturing variation of trikle emitters. Transactions of the ASAE, v.22, n.5, p.1034-1038, 1979. 
SPOONER, J.; HOUSE, C.H.; HOOVER, M.T.; RUBIN, A.R.; SILVERTHORNE Jr., R.; STEINBECK, S.J.; HARRIS, V.; UEBLER, R.L.; MARTIN, B.; SIEVERS,D.M. Performance evaluation of innovative and alternative on-site waste water treatment systems in Craven county, NC. In: NATIONAL SYMPOSIUM ON INDIVIDUAL AN SMALL COMMUNITY SEWAGE SYSTEMS, 8., Orlando, 1998. Proceedings. St. Joseph: ASAE, 1998. p.258-269.

TAJRISHY, M.A.; HILLS, D.J.; TCHOBANOGLOUS, G. Pretreatment of secundary effluent for drip irrigation. Journal of Irrigation and Drainage Engineering, v.120, n.4, p.716-731, 1994.

TELTSCH, B.; JUANICO, M.; AZOV, Y.; BEN-HARIM, I.; SHELEF, G. The clogging capacity of reclaimed wastewater: a new quality criterion for drip irrigation. Water Science and Technology. v.24, n.9, p.123-131, 1991.

UNKROTH, A.; WAGNER, V.; SAUERBREY, R. Laser assisted photochemical wastewater treatment. Oxidation technologies for water and wastewater treatment, 1997. $7 p$.

VERMEIREN, L. JOBLING, G.A. Irrigação localizada. Tradução de R.S. Gheyi et al. Campina Grande: UFPB, 1997. 218p. (Estudos FAO: Irrigação e Drenagem, 36).

VON SPERLING, M. Introdução à qualidade das águas e ao tratamento de esgotos. 2.ed. Belo Horizonte: Universidade Federal de Minas Gerais, 1996. $243 p$.

WATANABE, S.; METSUGI, M. Irrigation system. Official Gazette of the United States Patent Office, v.988, n.2, p.365, 1979. 
WIDRIG, D. L.; PEEPLES, J. A.; MANCL, K. M. Intermittent sand filtration for domestic wastewater treatment: effects of filter depth and hydraulic parameters. Applied Engineering in Agriculture, v.12, n.4, p.451-459, 1996.

WORLD HEALTH ORGANIZATION. Health guidelines for the use of wastewater in agriculture and aquiculture. Copenhagen: WHO, Regional Office for Europe, 1989. 1100p. (Technical Report, 54). 